\title{
QUANTIFICAÇÃO DE RISCO DE CRÉDITO: UMA APLICAÇÃO DO MODELO CREDITRISK+ PARA FINANCIAMENTO DE ATIVIDADES RURAIS E AGROINDUSTRIAIS
}

\author{
Luciano Gabas Stuchi
}

Dissertação apresentada à Escola Superior de Agricultura "Luiz de Queiroz", Universidade de São Paulo, para obtenção do título de Mestre em Ciências, Área de Concentração: Economia Aplicada.

P I R A C I C A B A

Estado de São Paulo - Brasil

Dezembro -2003 


\title{
QUANTIFICAÇÃO DE RISCO DE CRÉDITO: UMA APLICAÇÃO DO MODELO CREDITRISK+ PARA FINANCIAMENTO DE ATIVIDADES RURAIS E AGROINDUSTRIAIS
}

\author{
Luciano Gabas Stuchi \\ Engenheiro Agrícola
}

Orientador: Prof. Dr. JOÃO GOMES MARTINES FILHO

Dissertação apresentada à Escola Superior de Agricultura "Luiz de Queiroz", Universidade de São Paulo, para obtenção do título de Mestre em Ciências, Área de Concentração: Economia Aplicada.

P I R A C I C A B A

Estado de São Paulo - Brasil

Dezembro - 2003 


\section{Dados Internacionais de Catalogação na Publicação (CIP) DIVSÃO DE BIBLIOTECA E DOCUMENTACÃO - ESALQ/USP}

\section{Stuchi, Luciano Gabas}

Quantificação de risco de crédito: uma aplicação do modelo Creditrisk+para financiamento de atividades rura is e agroindustria is / Luciano Gabas Stuchi. - Piracic aba, 2003.

107 p. : il.

Dissertação (mestrado) - - Escola Superior de Agric ultura Luiz de Queiroz, 2003. Bibliografia.

1. Análise de risco 2. Crédito rural 3. Empréstimo bancário 4. Financiamento agríco

5. Indústria agnícola I. Título

CDD 338.13

“Permitida a cópia total ou parcial deste documento, desde que citada a fonte - O autor” 
DEDICO

Aos meus pais,

Angelo e Vera

e aos meus irmãos

Eliana, Daniel e Carolina. 


\section{AGRADECIMENTOS}

Nesta fase da dissertação, talvez a mais difícil, é necessário agradecer todos que, direta ou indiretamente, contribuíram para a realização desse trabalho. Começo agradecendo aos meus pais, por toda uma vida de dedicação, me incentivando em cada etapa, em cada nova conquista. Agradeço aos meus irmãos que, através do apoio e exemplo de disciplina no estudo, me fizeram atingir mais este degrau.

A todos os professores que tive contato durante esta jornada. Principalmente ao Prof. Dr. José Vicente Caixeta Filho, pela sua dedicação, apoio e paciência. Agradeço também aos professores Fernando Peres, Evaristo Neves e Pedro Marques, pelas dicas importantes ao longo deste trabalho. Um agradecimento especial ao Prof. Dr. Ricardo Shirota pela colaboração importante na discussão dos resultados deste trabalho.

A todos os amigos do Banco Itaú, principalmente ao Erlei Lima, pela paciência e precisão nas explicações que foram primordiais para o entendimento dos modelos.

A todos os funcionários do Departamento de Economia, Administração e Sociologia da Escola Superior de Agricultura “Luiz de Queiroz”, em especial a Maielli, Ligiana e Helena, vitais na elaboração desta dissertação.

Por fim, não menos importante, um agradecimento especial ao meu orientador Prof. Dr. João Martines Filho, pelo incentivo, paciência e precisão em todos os detalhes. Agradeço também a confiança que depositou em mim. 


\section{SUMÁRIO}

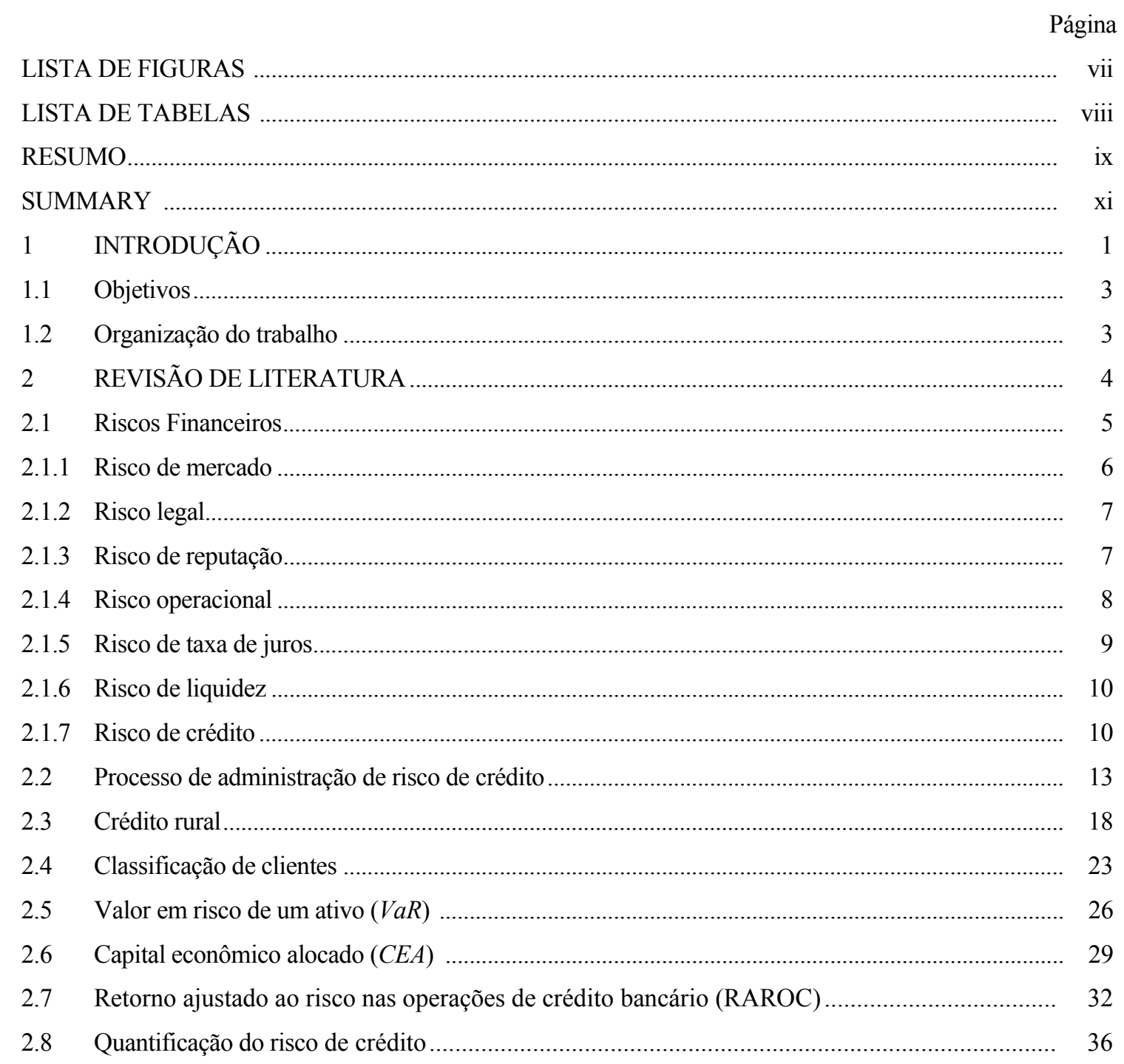




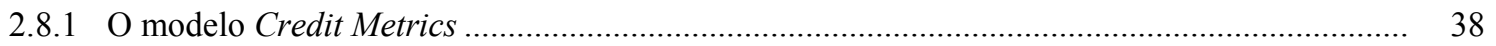

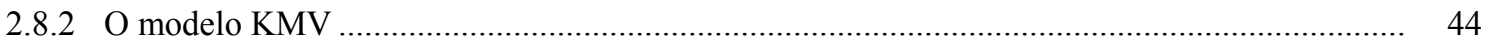

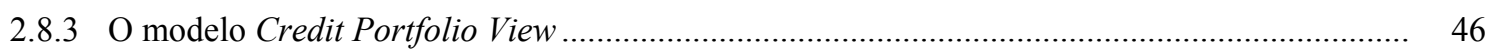

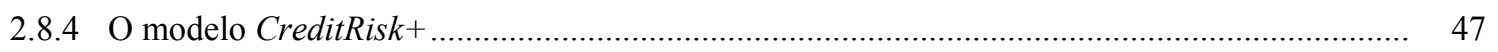

2.8.4.1 A estrutura do CreditRisk + ............................................................................................ 50

2.8.4.2 Função geradora de probabilidade (FGP) ........................................................................ 51

2.8.4.3 Distribuição dos eventos de inadimplência ........................................................................... 54

2.8.4.4Distribuição de perdas com taxas de inadimplências fixas ........................................................ 57

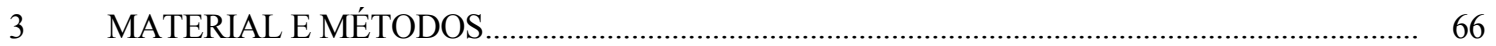

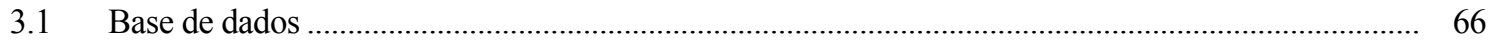

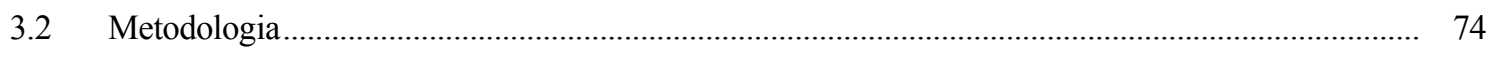

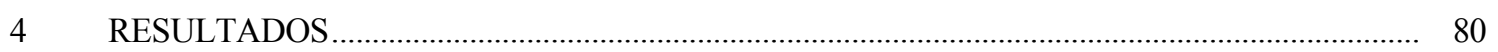

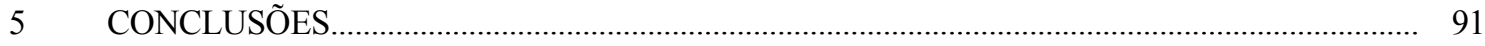

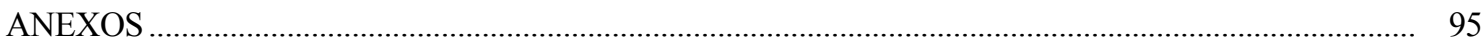

REFERÊNCIAS BIBLIOGRÁFICAS................................................................................................ 105 


\section{LISTA DE FIGURAS}

Página

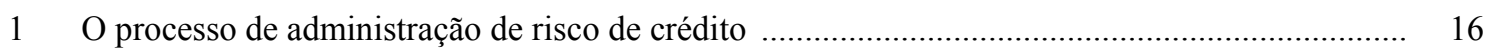

2 Evolução do crédito rural no Brasil ................................................................................. 19

3 Participação do sistema financeiro privado no volume total de crédito rural ........................... 21

4 Distribuição de perdas de uma carteira de empréstimos ....................................................... 30

5 Comparação entre retorno de mercado e retorno de crédito ..................................................... 36

6 Processo de determinação do $\operatorname{VaR}$ de um portfólio devido ao crédito ........................................ 39

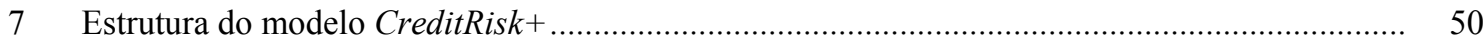

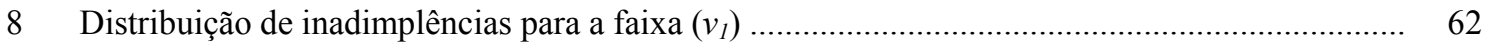

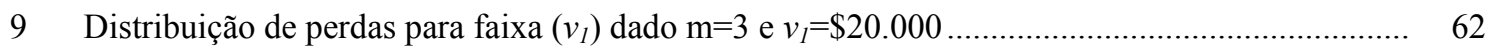

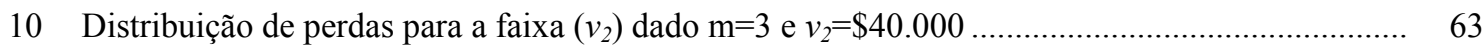

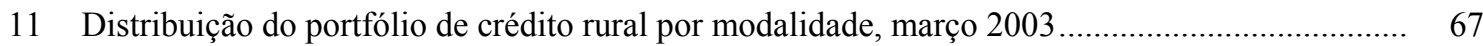

12 Distribuição do risco de crédito por setor de atividade ..................................................... 72

13 Montante de CEA sobre o risco de crédito de cada setor de atividade para o cenário 1 ............... 82

14 Montante de $C E A$ sobre o risco de crédito de cada setor de atividade para o cenário 2 ............... 83

15 Relação entre RAROC e spread para cada cenário .............................................................. 84

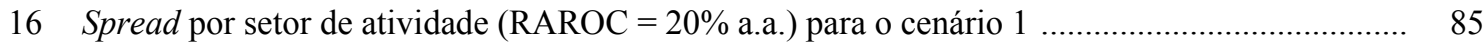

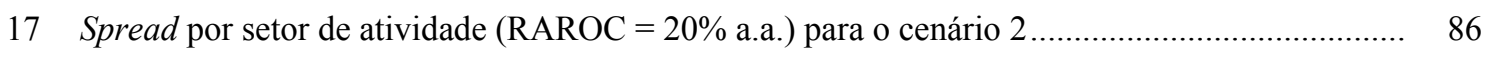

18 Total de risco de crédito, CEA e $P E$ para o cenário 1 .............................................................. 87

19 Total de risco de crédito, $C E A$ e $P E$ para o cenário 2 ............................................................ 88

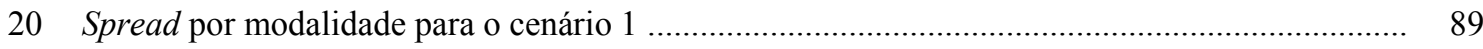

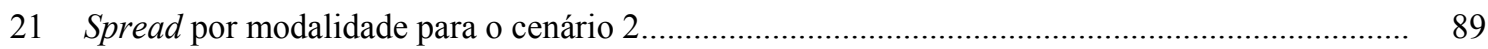




\section{LISTA DE TABELAS}

Página

1 Percentual mínimo de provisionamento por classificação da operação, em \% ............................... 24

2 Classificação correspondente ao atraso da operação, em dias ...................................................... 25

3 Taxas de retornos com crédito por classificação, dado CDI a 18\% a.a., em \% ............................. 41

4 Matriz de migração, em \% ............................................................................ 42

5 Marcação a mercado de um título com vencimento no Ano 3, em R\$ ............... 42

6 Taxas de retorno esperado para cada classificação do título.......................................................... 43

7 Retorno médio e volatilidade por classificação, em \% …............................................................... 43

8 Transformadas " $z$ " de algumas funções de variáveis discretas ....................................................... 54

9 Exemplo de probabilidade de inadimplência, dado $\mathrm{m}=3$, em $\%$................................................... 61

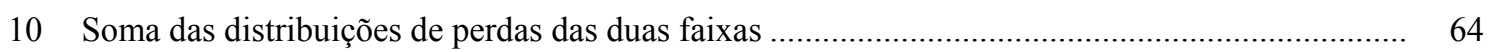

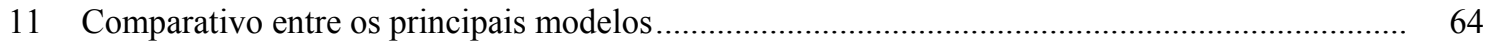

12 Dados de entrada por setor de atividade e classificação ................................................................. 68

13 Provisionamento e classificação por dias de atraso ................................................................... 73

14 Distribuição do risco de crédito do portfólio por classificação, em R \$ .......................................... 73

15 Premissas do modelo versus Resoluções do BACEN .................................................................. 74

16 Matriz de migração de clientes após um ano, em \% .................................................................. 78

17 Provisionamento BACEN versus matriz de migração de clientes, em \% …………....................... 79

18 Probabilidade acumulada por faixa de valor de perda, em \% ……............................................. 80

19 Resultados obtidos em cada cenário, em R \$ milhões ................................................................. 81 


\title{
QUANTIFICAÇÃO DE RISCO DE CRÉDITO: UMA APLICAÇÃO DO MODELO CREDITRISK+ PARA FINANCIAMENTO DE ATIVIDADES RURAIS E AGROINDUSTRIAIS
}

\author{
Autor: LUCIANO GABAS STUCHI
}

Orientador: Prof. Dr. JOÃO GOMES MARTINES FILHO

\section{RESUMO}

A atividade bancária envolve em suas operações diversas formas de riscos. Dentre esses riscos está o risco de crédito, ou risco de inadimplência, presente em transações em que a instituição se torna credora. Sua mensuração exige que se tenha conhecimento da probabilidade de inadimplência associada a cada classificação. Neste trabalho são apresentadas as principais metodologias de quantificação do risco de crédito como Credit Metrics, KMV, Credit Portfolio View e CreditRisk+. Esta última metodologia, juntamente com o conceito de RAROC (Risk Adjusted Return on Capital), é aplicada a um portfólio de financiamentos rurais e agroindustriais à pessoa jurídica, evidenciando o capital econômico alocado $(C E A)$ e o spread necessário para cobrir as perdas esperadas e inesperadas. Esse portfólio totaliza $\mathrm{R} \$ 1,42$ bilhões referentes ao mês de março de 2003. São construídos dois cenários com diferentes índices de inadimplência associados a cada classificação. $\mathrm{O}$ primeiro aproxima os percentuais de 
provisionamento definidos pelo Banco Central do Brasil (BACEN) para índices de inadimplência e o segundo utiliza os percentuais obtidos por uma matriz de migração de clientes vinculados às atividades rurais e agroindustriais para o período de 2000 a 2002. Observa-se como resultado que ocorre uma maior alocação de capital econômico para setores rurais e agroindustriais que possuem risco concentrado como o setor de fumo, com total de financiamentos em $\mathrm{R} \$ 202,9$ milhões e $C E A$ de $\mathrm{R} \$ 78,9$ milhões e $\mathrm{R} \$ 114,0$ milhões para o cenário 1 e cenário 2, respectivamente. As modalidades de financiamentos rurais e agroindustriais de custeio e desconto de Nota Promissória Rural (NPR) são responsáveis por cerca de $75 \%$ do total do portfólio. No entanto, estas modalidades apresentam a necessidade de um spread menor para cobrir as perdas esperadas e inesperadas com crédito, sinalizando uma composição de clientes com melhor classificação. Observa-se também que os menores spreads ocorrem nos setores de industrialização, principalmente na indústria de cigarros, laticínios, soja e derivados, e resinas de fibras e fios sintéticos. Já os setores como fumo, moagem de trigo e abate de aves, tiveram maiores spreads. 


\section{MEASURES OF CREDIT RISK: AN APLICATION OF THE CREDITRISK+ MODEL TO FINANCING OF FARM AND AGRIBUSINESS ACTIVITIES}

Author: LUCIANO GABAS STUCHI

Adviser: Prof. Dr. JOÃO GOMES MARTINES FILHO

\section{SUMMARY}

The banking activity involves several forms of risk in its operation. Among these risks, there is one called the credit risk, or the default risk. Its measurement requires that the financial institution owns knowledge about the default probability associated with each rating class. In this research, four models of credit risk are discussed: Credit Metrics, KMV, Credit Portfolio View, and CreditRisk+. The last model, the CreditRisk+, associated with the concept of Risk Adjusted Return on Capital (RAROC) is applied to a financial portfolio to the farm and agribusiness sectors. Under this analysis, the indicators of allocated economic capital and spreads are discussed with respect to the expected and unexpected losses. The data used in this analysis are unique and represent the total amount of loans as of March 2003, R\$ 1.42 billions, made by a specific commercial bank to the commercial farms and agribusiness companies. Two scenarios are evaluated considering different level of default risks associated with each rating class. The first scenario uses the provisional indexes defined by the Brazilian 
Central Bank. The second scenario uses a computable migration matrix over the period 2000 through 2002. The results show that the higher amount of allocated economic capital occurs in the tobacco sector in which the total amount of loans is $\mathrm{R} \$ 202.9$ millions. The total amount of allocated economic capital is $\mathrm{R} \$ 78.9$ million and $\mathrm{R} \$ 114$ million under scenarios 1 and 2 respectively. The data used in this study show that seventy-five percent of the totals of loans has as a purpose for operating expenses and discount of agribusiness promissory notes. These loans show the lowest spreads to cover expected and unexpected losses with the credit operation. The lowest spread is observed at the following processing sectors: tobacco industries, milk and soybean processors, and fiber resins and synthetic fibers. On the other hand, the sectors that show the highest spreads are: tobacco farms, wheat processors, and poultry slaughter houses. 


\section{INTRODUÇÃO}

Os bancos e instituições financeiras têm fornecido uma grande proporção dos recursos que uma economia necessita para financiar suas atividades, além de serem parte importante no sistema de pagamentos do país em que se situam. Porém, a atividade bancária envolve em suas operações diversas formas de riscos. Esses riscos, quando bem entendidos e quantificados pelos supervisores bancários, asseguram uma avaliação e gerenciamento eficaz da instituição financeira.

O termo risco pode ser definido como sendo o grau de incerteza a respeito de um evento. Quanto maior o nível de risco de um ativo, maior deve ser a expectativa de retorno deste ativo. Dessa forma, as instituições financeiras têm buscado ferramentas para quantificar e gerenciar o risco, e não evitá-lo. Dentre os principais riscos presentes na atividade bancária, tem-se o risco de crédito ou risco de inadimplência, presente em transações em que a instituição se torna credora. Esse risco pode ser definido como uma medida de incerteza relacionada ao recebimento de um valor compromissado. Sua mensuração exige que se tenha conhecimento prévio da probabilidade de inadimplência associada a classificação do crédito, permitindo neutralizar os custos dessa inadimplência no preço de cada operação.

O financiamento destinado ao setor rural e agroindustrial tem crescido nas instituições financeiras privadas, principalmente a partir de 1997, com a exigibilidade, imposta pelo Banco Central do Brasil (BACEN), de aplicação em 25\% do total de depósitos à vista em operações destinadas a esse setor. Junto com esse crescimento tem crescido a preocupação com a mensuração precisa do risco envolvido nessas operações. 
Além disso, é necessário conhecer as características particulares presentes nesta modalidade de empréstimo, que sofrem influência, por exemplo, de fatores climáticos como geadas e estiagem podendo proporcionar quebra de safra.

Metodologias que ajustam o retorno do portfólio de crédito em função do risco envolvido têm sido empregadas pelas instituições financeiras. Essas metodologias procuram estabelecer uma alocação de recursos de modo que a rentabilidade seja, no mínimo, igual a perda máxima esperada com crédito, em um determinado nível de significância.

No presente trabalho são analisadas as principais metodologias disponíveis para medir o risco de crédito como o Credit Metrics apresentado pelo JP Morgan em 1997, o modelo KMV apresentado pela KMV Corporation em 1989, o Credit Portfolio View apresentado pela Mckinsey and Co. em 1997 e o CreditRisk+ apresentado pelo Credit Suisse Financial Products (CSFP) em 1997. Esta última metodologia é aplicada a um portfólio de financiamentos rurais e agroindustriais destinados à pessoa jurídica, obtendo-se o $\operatorname{VaR}$ e o capital econômico alocado $(C E A)$ necessários para determinação do RAROC (Risk Adjusted Return on Capital) do portfólio.

Os índices de inadimplência de cada classificação, considerados na alimentação do modelo CreditRisk+, são obtidos de maneiras distintas, determinando a construção de dois cenários. O primeiro aproxima os percentuais de provisionamento definidos pelo BACEN para índices de inadimplência e o segundo utiliza os percentuais obtidos por uma matriz de migração de clientes vinculados às atividades rurais e agroindustriais para o período de 2000 a 2002. O portfólio de financiamentos rurais e agroindustriais totaliza $\mathrm{R} \$ 1,42$ bilhões referentes ao mês de março de 2003. Isso representa mais de $10 \%$ do total de financiamentos rurais e agroindustriais que se encontrava alocado no sistema financeiro privado no mesmo período. Além disso, após a quantificação do risco envolvido em cada operação, o trabalho ilustra o spread a ser cobrado para neutralizar as perdas esperadas e inesperadas de crédito em diferentes setores de atividades agroindustriais e modalidades de financiamentos. 


\subsection{Objetivos}

O principal objetivo deste estudo é quantificar o risco envolvido em operações de empréstimos bancários, aplicando a metodologia utilizada pelo CreditRisk + na determinação do valor em risco da carteira $(V a R)$ e do capital econômico alocado $(C E A)$.

Em seguida utiliza-se o conceito RAROC (Risk Adjusted Return on Capital) para determinar o retorno do portfólio em estudo.

Estes conceitos são aplicados em uma carteira de financiamentos rurais e agroindustriais à pessoas jurídicas, semelhante à encontrada nas principais instituições financeiras nacionais. Dessa forma, o trabalho procura ilustrar a influência no retorno do portfólio quando ocorrem variações na probabilidade de inadimplência de cada classificação. Busca mostrar também qual deve ser o spread a ser cobrado em cada operação, dado um nível de retorno.

\subsection{Organização do trabalho}

O estudo está dividido em cinco capítulos, sendo o primeiro uma breve introdução sobre a mensuração do risco de crédito e dos objetivos perseguidos.

No segundo capítulo é apresentada uma revisão de literatura evidenciando os principais tipos de riscos financeiros na atividade bancária, ilustrando mais detidamente as principais variáveis envolvidas na determinação do risco de crédito, bem como algumas metodologias utilizadas na administração de carteiras.

No terceiro capítulo são descritos os materiais e métodos necessários para o processo de quantificação do risco de crédito do portfólio de financiamentos rurais e agroindustrias. No quarto capítulo, são ilustrados os resultados obtidos para este portfólio. Por fim, no quinto capítulo apresentam-se as conclusões. 


\section{REVISÃO DE LITERATURA}

A atividade bancária envolve em suas operações diversas formas de riscos. Estes riscos precisam ser explorados e entendidos pelos supervisores bancários, assegurando uma avaliação e gerenciamento eficaz da instituição financeira. A literatura apresenta diferentes formas de agrupamento de riscos, provocando, muitas vezes, distorções em suas definições. Para este trabalho, adota-se o agrupamento de riscos definido pelo Comitê de Supervisão Bancária da Basiléia, órgão responsável pela regulamentação bancária mundial.

Após a definição dos principais riscos envolvidos na atividade bancária, este capítulo ilustra o processo de administração de risco de crédito, evidenciando os principais pontos que uma instituição financeira deve levar em consideração na administração de seu portfólio de crédito. Nesta etapa, também são evidenciadas as principais considerações contidas no Acordo da Basiléia de 1988 e as modificações inseridas no Novo Acordo da Basiléia, com previsão de implementação para o ano de 2007. Em seguida, discute-se o panorama geral do crédito rural, ilustrando como esta modalidade de empréstimo tem evoluído dentro das instituições financeiras privadas.

$\mathrm{Na}$ etapa seguinte, descreve-se, de maneira sucinta, o processo de classificação de clientes baseado nas normas e resoluções do BACEN como forma de ilustrar quais os principais critérios utilizados na atribuição de uma classificação a um cliente de uma determinada instituição financeira. Este processo de classificação de clientes tem como objetivo explicitar quais são os principais pontos que levam uma instituição financeira a classificar seus clientes. 
Faz-se necessário mostrar as principais abordagens utilizadas na quantificação do risco de crédito e como a classificação do cliente influi na expectativa de perda da operação. Sendo assim, ilustra-se o conceito de valor em risco $(V a R)$ de um ativo, mostrando como este conceito é utilizado na obtenção do capital econômico alocado $(C E A)$ de um portfólio de crédito e como este último alimenta a equação utilizada na determinação do retorno ajustado ao risco (RAROC).

Por fim, faz-se uma breve descrição dos principais modelos utilizados na quantificação do risco de crédito, mostrando os diferentes tipos de dados que cada um necessita, bem como suas limitações de implementação no cenário brasileiro.

Cabe lembrar que esta revisão de literatura não busca esgotar os trabalhos publicados sobre os assuntos abordados, mas busca de forma simplificada apresentar os principais conceitos envolvidos na quantificação de risco de crédito enfrentado pelas instituições financeiras.

\subsection{Riscos financeiros}

Os riscos financeiros podem ser divididos em sete diferentes tipos:

I) risco de mercado;

II) risco legal;

III) risco de reputação;

IV) risco operacional;

V) risco de taxa de juros;

VI) risco de liquidez; e

VII) risco de crédito. 
Dessa forma, faz-se necessário uma breve definição de cada tipo de risco enfrentado por uma instituição financeira.

\subsubsection{Risco de mercado}

O risco de mercado pode ser definido como aquele decorrente de movimentos adversos nos preços dos ativos, representando incertezas relacionadas ao retorno esperado de um investimento. Este tipo de risco ocorre devido a variações em fatores como taxas de câmbio, preços de ações e commodities. Quando ocorrem períodos de instabilidade das taxas de câmbio, por exemplo, os riscos inerentes às operações com estas taxas aumentam. Este tipo de risco fica mais acentuado à medida que a instituição financeira possui quantidade expressiva de operações em moeda estrangeira. $O$ caso “Marka/Cidam" ocorrido em princípios de 1999, amplamente divulgado pela mídia, foi um exemplo de risco de mercado, onde uma desvalorização cambial afetou a estrutura de capital desses bancos, fazendo com que o BACEN tivesse que intervir para que estes não "quebrassem". Apesar da intervenção do BACEN estes bancos acabaram "quebrando". O motivo utilizado para ajudar estes bancos era o risco de crise sistêmica, onde todo o sistema financeiro corria risco de "quebrar". Motivo esse bastante questionado na época.

O risco de mercado pode ser medido das seguintes formas:

I) risco de mercado relativo; e

II) risco de mercado absoluto.

O risco de mercado relativo é uma medida da variação dos rendimentos de uma carteira de investimentos em relação a um índice utilizado como base. Por exemplo, ao se indexar carteiras de ações ao índice FGV-100, o risco de mercado relativo mede a possível variação dos rendimentos desta carteira em relação ao índice FGV-100.

$\mathrm{O}$ risco de mercado absoluto mede as perdas de uma carteira de investimentos sem qualquer relação a índices de mercado. O cálculo do risco de 
mercado absoluto possui diferentes formas de mensuração. Dentre as mais citadas, destacam-se o cálculo pelo desvio padrão dos retornos passados, cálculo pela raiz quadrada da semivariância dos retornos passados e cálculo de valor em risco (VaR). A metodologia do $\operatorname{VaR}$ vem tendo intensa utilização nas instituições financeiras com aplicação ampliada, mais recentemente, para se medir risco de crédito. Este tipo de metodologia será analisado mais detidamente no item 2.5 a seguir.

\subsubsection{Risco legal}

Os riscos legais que podem afetar uma instituição financeira são advindos, principalmente, de ações judiciais movidas contra a instituição, desvalorizando seus ativos em intensidades inesperadamente altas. Um processo judicial movido contra uma determinada instituição pode provocar perdas não só para a instituição em questão como para todo o setor bancário. Pode-se citar ações movidas pelo Ministério Público e por associações de defesa do consumidor contra instituições financeiras, versando, principalmente, sobre taxas de juros elevadas e tarifas abusivas.

Uma outra possibilidade de risco legal a que as instituições financeiras estão suscetíveis ocorre quando estas adotam novos tipos de transação sem estabelecer o direito de uma contraparte de acordo com as leis vigentes. Nesse caso, pode-se citar ações movidas contra instituições financeiras por cobrarem tarifas de produtos como cartões de crédito que não foram contratados pelo cliente (correntista).

Por fim, pode-se citar a ocorrência de risco legal quando, no decorrer de um contrato, existe mudança nas leis vigentes, penalizando a instituição financeira. Esse tipo de situação ocorre principalmente em mudanças de governo que determinam alterações nas normas que regulam as atividades das instituições financeiras.

\subsubsection{Risco de reputação}

O risco de reputação, também definido como risco de imagem, decorre de veiculação de informações que afetam negativamente a imagem da instituição. Esse 
risco pode se originar, entre outras causas, de falhas operacionais ou de deficiências no cumprimento de leis e regulamentos relevantes. Pode ser conseqüência de todos os outros riscos que uma instituição financeira está envolvida. Quando ocorre, por exemplo, uma ação ou condenação judicial movida contra uma determinada instituição em que o fato se torna público, esta instituição tem sua imagem danificada.

Uma falha num sistema central de processamento de dados pode ocasionar a interrupção na comunicação com as agências da instituição financeira. Esse tipo de falha deixa evidente aos clientes a fragilidade de suas transações, danificando a imagem da instituição com relação à segurança das informações. Outros exemplos poderiam ser citados, mas o que é necessário enfatizar é que a imagem de uma instituição precisa ser preservada, já que é esta imagem que transmite confiança aos depositantes, credores e ao mercado em geral.

\subsubsection{Risco operacional}

O risco operacional, também denominado risco de controle, surge da falta de consistência e adequação dos sistemas de controle interno e/ou deficiências graves em sistemas tecnológicos de informação. Além disso, podem ser citadas falhas de gerenciamento e erros humanos. Dessas falhas decorrem erros, fraudes ou deficiência de desempenho das atividades de transação, concessão de crédito e administração, que podem ocasionar perdas financeiras.

Alguns autores dividem o risco operacional em dois níveis, sendo o primeiro de nível técnico, em que o sistema de informação ou as medidas de risco são deficientes e o segundo de nível organizacional, em que ocorrem deficiências nos sistemas de informática, mostrando que não adianta uma instituição ter ferramentas adequadas de mensuração de risco se não possui sistemas informatizados para armazenagem e controle das variáveis.

De maneira mais ampla, o risco operacional pode ser dividido em três níveis: 
I) risco organizacional;

II) risco de operação; e

III) risco de pessoal.

O risco organizacional está relacionado com uma organização ineficiente, administração inconsistente, fluxo de informações internos e externos deficientes, responsabilidades mal definidas e estrutura passível de fraudes.

O risco de operação está relacionado com problemas como processamento e armazenagem de dados passíveis de erros, confirmações incorretas ou sem verificação criteriosa, sistemas de telefonia, sistemas elétricos e sistemas computacionais mal dimensionados.

Risco de pessoal está relacionado com problemas como empregados nãoqualificados, pouco motivados, desonestos e com ações de má fé, causando perdas para a instituição e para clientes.

\subsubsection{Risco de taxa de juros}

O risco de taxa de juros se refere à exposição da situação financeira de uma instituição a movimentos adversos nas taxas de juros. Quando ocorrem grandes oscilações nas taxas de juros, podem ocorrer declínios nos ganhos e no valor de um ativo. Como muitos dos ítens que compõem os balanços patrimoniais das instituições financeiras geram custos e receitas indexados às taxas de juros, quando estas são instáveis, o ganho das instituições também será.

Um exemplo de risco de taxa de juros é uma eventual perda de valor de títulos públicos ou privados devido a mudanças na taxa de juros vigente. Outro exemplo pode ser ilustrado quando, em uma eventual elevação dos juros, ocorre encarecimento dos custos de capitação de recursos feita pelas instituições financeiras, sem que estas possam repassá-los ao cliente final. 
O risco de taxa de juros na atividade bancária é considerado comum, porém, quando excessivo, pode representar uma significativa ameaça para os resultados e para a estrutura de capital de uma instituição financeira.

\subsubsection{Risco de liquidez}

O risco de liquidez está diretamente ligado ao montante de capital necessário que uma instituição financeira deve ter disponível para absorver todas as possíveis perdas geradas por todos os riscos assumidos. O risco de liquidez pode ser ilustrado quando o titular de um passivo, por exemplo, o depositante de um banco, exige, em troca de seus direitos financeiros, o pagamento imediato em dinheiro. Se vários depositantes decidem sacar seu dinheiro simultaneamente, a instituição financeira é obrigada a obter recursos adicionais e muitas vezes se desfazer de ativos a custos elevados, afetando sua rentabilidade. Em casos extremos de liquidez insuficiente, pode-se ter risco de insolvência.

Para que uma instituição financeira não se torne insolvente, é necessário dimensionar um montante de capital que possa superar todas as perdas potenciais assumidas. O principal desafio dos gerenciadores de carteira têm sido determinar quais os níveis mínimos de capital que uma instituição necessita para que mantenha padrões de solvência aceitáveis em termos nacionais e internacionais. A questão chave é que todos os riscos assumidos geram perdas potenciais e a última proteção para essas perdas é o capital. No entanto, se esse capital não está devidamente ajustado e as perdas acontecem, a instituição não consegue honrar todas as suas obrigações, se tornando insolvente.

\subsubsection{Risco de crédito}

O risco de crédito é um dos riscos mais comuns enfrentados por uma instituição financeira, uma vez que sua atividade básica é a concessão de empréstimos. Mesmo sendo comum na atividade bancária, sua quantificação é, na maioria das vezes, 
complexa. Para se ilustrar o risco de crédito, objeto de estudo deste trabalho, é necessário uma breve descrição do conceito de crédito.

Enquanto que para Schrickel (1997), crédito pode ser definido como sendo ato de vontade, ou disposição de alguém de destacar ou ceder, temporariamente parte de seu patrimônio a um terceiro, com a expectativa de que esta parcela volte à sua posse integralmente, após decorrer o tempo estipulado, para Securato (2000), o termo crédito procura estabelecer uma relação de confiança entre as partes quando se faz uma operação qualquer. Conforme esse autor, as definições mais comuns de nossos dias abordam claramente o crédito comercial e o bancário, já subentendendo as operações de empréstimo de dinheiro com a contrapartida dos juros.

O risco de crédito, segundo Figueiredo (2001), é a conseqüência de uma transação financeira contratada entre um fornecedor de fundos (doador do crédito) e um usuário (tomador do crédito). $\mathrm{O}$ puro ato de emprestar uma quantia a alguém traz embutido em si a probabilidade de ela não ser recebida, a incerteza em relação ao retorno. Na essência, o risco de crédito pode ser definido como o risco de uma contraparte não honrar seu compromisso em um acordo de concessão de crédito.

Os riscos de crédito surgem quando as contrapartes não desejam ou não são capazes de cumprir suas obrigações contratuais. Dentro deste contexto, Abe (2002), aponta que o crédito é uma forma de obtenção de recursos financeiros para realizar investimentos ou suprir necessidades. Quando se vende uma mercadoria ou serviço, por exemplo, e o pagamento ocorrerá posteriormente, um crédito está sendo concedido. Os recursos envolvidos numa operação de crédito não precisam ser próprios, podem ser de terceiros, como é o caso das instituições financeiras. Estas instituições atuam como um agente que capta o recurso do cliente com excesso de recursos e os repassa por sua conta e risco para os tomadores em operações típicas de crédito bancário. Devido à possibilidade de não ocorrer o pagamento na data do vencimento, qualquer crédito associa-se a noção de risco; chama-se então de risco de crédito. 
Uma definição mais abrangente do risco de crédito pode ser ilustrada como sendo uma medida de incerteza relacionada ao recebimento de um valor compromissado, a ser pago pelo tomador do empréstimo, descontadas as expectativas de recuperação e execução de garantias. De maneira geral, o risco de crédito pode ser dividido nas seguintes áreas:

I) risco de inadimplência;

II) risco de degradação de crédito;

III) risco de degradação de garantias;

IV) risco soberano; e

V) risco de concentração de crédito.

O risco de inadimplência pode ser definido como o risco de perda pela incapacidade de pagamento de um empréstimo. Um exemplo é o não pagamento de juros e/ou principal de um crédito pessoal ou cartão de crédito. Esse tipo de risco é a essência do risco de crédito, cuja definição geralmente associa-se ao risco de inadimplência.

O risco de degradação de crédito pode ser definido como risco de perda pela degradação da qualidade creditícia do tomador de um empréstimo ou emissor de um título, levando a uma diminuição no valor de suas obrigações. Pode-se citar como exemplo as perdas em títulos soberanos pela redução da classificação do país emissor.

Define-se risco de degradação de garantias como sendo o risco de perdas pela degradação da qualidade das garantias oferecidas pelo tomador de empréstimo. Como exemplo pode-se citar a depreciação das garantias depositadas em bolsas de derivativos. No caso de necessidade de execução dessas garantias, o valor final passa a ser inferior ao valor inicial do depósito. 
O risco soberano pode ser definido como o risco de perdas pela incapacidade de um tomador de empréstimo, localizado em outro país, honrar seus compromissos em função de restrições impostas por seu país sede. Transações que envolvam transferências de títulos ou de câmbio entre dois países podem ser dadas como exemplo de risco soberano.

A concentração de crédito envolve o risco de perdas em decorrência da não diversificação de investimentos. Uma concentração de empréstimos, por exemplo, em um determinado setor da economia pode gerar perdas excessivas numa eventual crise deste setor se comparadas a um portfólio diversificado em vários setores não correlacionados.

Observa-se que os riscos financeiros apresentados neste capítulo estão diretamente interligados. Isso mostra que nem sempre é fácil definir o tipo de risco presente em uma determinada situação. Dependendo da ótica sob a qual o problema é observado, o tipo de risco pode variar. Tomando-se como exemplo um banco " $\mathrm{A}$ " que tenha sofrido perdas substanciais no mercado acionário em função de aplicação mal sucedida em um grupo de ações que tiveram queda brusca de valor, tem-se o risco de mercado. Devido a estas perdas, o banco "A" não é capaz de honrar seus compromissos com o banco "B". O banco "B" passa a enfrentar risco de crédito devido ao possível não pagamento de compromissos assumidos pelo banco "A". Dessa forma, o que para o banco "A" é risco de mercado, para o banco "B" é risco de crédito.

\subsection{Processo de administração de risco de crédito}

O processo de administração de risco de crédito tornou-se de extrema importância para as instituições financeiras, principalmente quando estas passaram a ter spreads menores. Dando ênfase à mensuração mais precisa do risco de crédito, a questão passou a ser como precificar e controlar as perdas potenciais oriundas de inadimplências.

Segundo Jorion (1997), o risco de crédito se transformou numa das questõeschave enfrentadas pela indústria de derivativos na década de 1990. O risco de crédito 
abrange o risco de inadimplência e o risco de mercado. O risco de inadimplência consiste na avaliação objetiva da probabilidade de uma contraparte ficar inadimplente, e o risco de mercado mede o prejuízo financeiro que ocorrerá caso o cliente não consiga honrar seus compromissos.

Em meados de 1988, o Comitê da Basiléia, vinculado ao BIS, Bank for International Settlements, divulgou o relatório International Convergence of Capital Measurements and Capital Standards, base do Acordo de Capital da Basiléia. Este documento estabelecia os padrões mínimos de capital para as instituições financeiras dos países membros do G-10. A composição do G-10 é formada por representantes de autoridades de supervisão bancária e bancos centrais de doze países, quais sejam, Bélgica, Canadá, França, Alemanha, Itália, Japão, Luxemburgo, Holanda, Suíça, Suécia, Reino Unido e Estados Unidos.

Motivado pela percepção de que o ambiente de alta concorrência estava levando as instituições financeiras a buscar graus maiores de alavancagem, o Comitê da Basiléia estabeleceu percentual mínimo de capitalização da indústria bancária de $8 \%$ de seus ativos ajustados ao risco de crédito. No Brasil, o BACEN adotou política mais conservadora exigindo percentual mais elevado, que atualmente é de $11 \%$.

Segundo Securato (2002), os méritos do acordo da Basiléia foram amplamente reconhecidos na década de 90 , e suas indicações passaram a ser aceitas como padrão de segurança em mais de 100 países.

As crises da Ásia (1997) e Rússia (1998) contribuíram para o incremento da preocupação do sistema financeiro internacional com os riscos a que os seus diversos sistemas bancários estavam expostos. Dessa forma, o aperfeiçoamento do controle do risco de crédito, bem como a exigência de capital mínimo para riscos de mercado foram objetos de emendas ao Acordo da Basiléia original.

O Novo Acordo da Basiléia, com implementação prevista para 2007, revoluciona a metodologia de cálculo de capital mínimo para as Instituições Financeiras, 
tornando-a mais sensível aos fatores de riscos assumidos por cada instituição. Adicionalmente, deverá haver um benefício para as instituições financeiras que adotarem modelos internos de gerenciamento de risco mais desenvolvidos, permitindo menor exigência de capital. Este Novo Acordo da Basiléia está baseado em três pilares:

I) capital mínimo (“pilar 1”);

II) supervisão bancária (“pilar 2"); e

III) transparência (“pilar 3").

O "pilar 1" estabelece os requisitos mínimos de capital, privilegiando os modelos proprietários das instituições financeiras. A revisão do Acordo de Basiléia apresenta três opções para mensurar risco de crédito (método padronizado; modelo interno básico e modelo interno avançado) e, além disso, incorpora a mensuração do risco operacional.

Atualmente, a alocação de capital para risco de crédito é função da categoria do tomador (isto é, dívidas soberanas, bancárias ou empresariais). No Novo Acordo da Basiléia, o critério para alocação será baseado na classificação de risco da contraparte, dada por uma agência de classificação ou pelo próprio banco.

Para avaliar a alocação de capital econômico para cobertura do risco operacional, o Novo Acordo da Basiléia propõe três níveis de sofisticação: indicador básico, padronizado e mensuração interna. O método de indicador básico, como o próprio nome diz, utiliza um indicador de risco operacional para uma atividade total do banco. O método padronizado especifica indicadores diferentes para diferentes áreas de negócios. O método de mensuração interna exige que o banco utilize seus dados internos de perdas na estimativa do capital necessário.

O "pilar 2" diz respeito ao processo de fiscalização bancária. A nova estrutura exige que o Banco Central de cada país assegure que suas instituições financeiras tenham processos internos sólidos para avaliar a adequação de seu capital em 
uma análise completa de seus riscos e o enquadramento dos modelos utilizados, dentro das alternativas propostas pelo Novo Acordo da Basiléia. A utilização de modelos proprietários, proposta pelo Comitê de Basiléia, dependerá de trabalho conjunto entre o BACEN e as instituições financeiras nacionais.

O "pilar 3" visa amparar a disciplina de mercado, estabelecendo recomendações e requisitos de divulgação em várias áreas, incluindo a forma que a instituição financeira calcula sua adequação de capital e seus métodos de avaliação de risco.

Observa-se que é importante para cada instituição financeira definir e aperfeiçoar seu processo de administração de risco de crédito, de forma a otimizar sua alocação de capital e melhor precificar suas operações. Em seu trabalho, Prado et al. (2000) mostram uma visão geral do processo de administração de risco de um portfólio de crédito. Este processo pode ser ilustrado pela Figura 1.

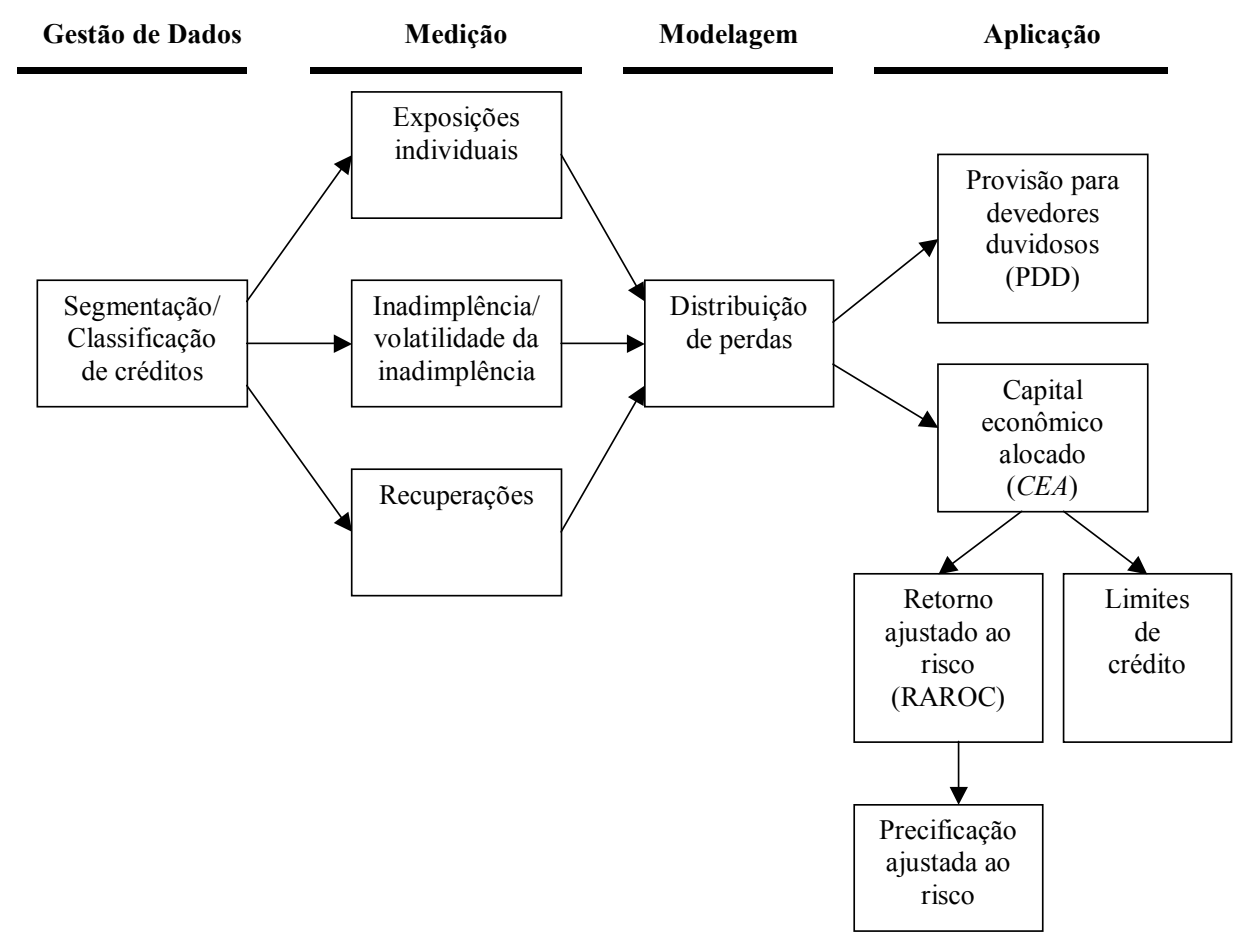

Figura 1 - O processo de administração de risco de crédito.

Fonte: Prado et al. (2000) 
A etapa de Gestão de Dados, ilustrada na Figura 1, corresponde ao processo de segmentação/classificação de créditos, com a utilização de um sistema de banco de dados relacional que proporcione ao analista uma visão segmentada do portfólio. A maioria das instituições financeiras possui internamente um sistema de classificação de clientes que considera as características de cada tomador, proporcionando a segmentação e a classificação dos créditos de acordo com o risco a estes atribuídos. O processo de classificação de clientes está ilustrado com mais detalhes no item 2.4. Depois de classificados e segmentados, os empréstimos alimentam um banco de dados, finalizando a etapa de gestão.

A fase relacionada à medição dos dados refere-se à obtenção das exposições individuais, probabilidades de inadimplência e suas volatilidades, assim como taxas de recuperação. Nesta etapa, mede-se a probabilidade de perda e recuperação de cada empréstimo individualizado, permitindo associar o risco de perda líquida que cada exposição pode proporcionar. A determinação do risco associado a cada empréstimo permite aos gerenciadores de carteira determinar qual a melhor distribuição de perdas que deve ser utilizada na fase de modelagem. Algumas formas de modelagem são apresentadas no item 2.8 .

No final do processo de administração de risco de portfólio de crédito, após ter escolhido a distribuição de perdas, surgem várias aplicações possíveis. Dentre essas, podem ser citadas:

I) perdas esperadas;

II) capital econômico alocado $(C E A)$; e

III) RAROC (Risk Adjusted Return on Capital).

As perdas esperadas determinam o valor mais adequado de provisão para devedores duvidosos (PDD) relativo ao portfólio. O provisionamento para as perdas 
esperadas geralmente é feito baseando-se nas determinações do BACEN. Isso está ilustrado com mais detalhes no item 2.4.

O capital econômico alocado (CEA) pode ser utilizado para definir limites de exposições de crédito a fatores como região geográfica, canal de distribuição ou origem, clientes individuais, grupos econômicos, tamanho das posições agregadas, tipos de instrumentos, tipos de garantias e moedas. O CEA também pode ser utilizado na determinação do RAROC (retorno ajustado ao risco nas operações de crédito). $\mathrm{O}$ RAROC permite que as exposições de crédito sejam comparadas em uma base ajustada ao risco, possibilitando técnicas de precificação mais precisas para as operações. Os conceitos envolvidos nas metodologias de $C E A$ e RAROC estão descritos em detalhes nos itens 2.6 e 2.7 , respectivamente.

O processo de administração de risco de portfólio de crédito, descrito na Figura 1, tem sido amplamente discutido nas instituições financeiras. Sua implementação, amparada por uma modelagem de dados consistentes, deve satisfazer os principais aspectos descritos no Novo Acordo de Basiléia. Com isso, as instituições financeiras passariam a utilizar processos internos de mensuração de risco de crédito. Como mencionado anteriormente, a utilização desses processos internos depende de trabalho conjunto entre o BACEN e as instituições financeiras. Isso é necessário para assegurar que o montante de capital, determinado por esses processos, leve em consideração, uma análise completa de todos os riscos envolvidos.

\subsection{Crédito rural}

O crédito rural tem sido elemento de extrema importância para o financiamento da produção agrícola do país, seja na forma de custeio, comercialização, investimento ou aquisição de máquinas e equipamentos, proporcionando ao produtor ou empresa rural a obtenção de recursos necessários para que seus produtos possam ser produzidos. 
Nos últimos anos ocorreram mudanças profundas na forma de atuação do governo no crédito rural. Para Gasques \& Conceição (2001), a principal mudança foi com relação às fontes de recursos, onde o financiamento apoiado pesadamente nos recursos do Tesouro se mostrava esgotado. Recentemente, a participação da fonte Tesouro já representava cerca de $0,02 \%$ do total dos financiamentos concedidos, ficando por conta dos recursos obrigatórios (Fundo de Amparo ao Trabalhador - FAT) e Poupança Rural a representatividade de $79 \%$ dos recursos aplicados no ano de 2000 . Um outro direcionamento do governo também foi apontado pelo autor com relação ao financiamento da comercialização, onde utilizando-se de mecanismos já existentes e de outros que têm sido criados, o governo vem estimulando a participação da iniciativa privada na comercialização.

Apesar dos esforços do governo federal para aumentar a oferta de crédito no setor rural, sem penalizar os recursos do Tesouro, observa-se pela Figura 2 que o volume de crédito está abaixo de patamares atingidos em anos anteriores.

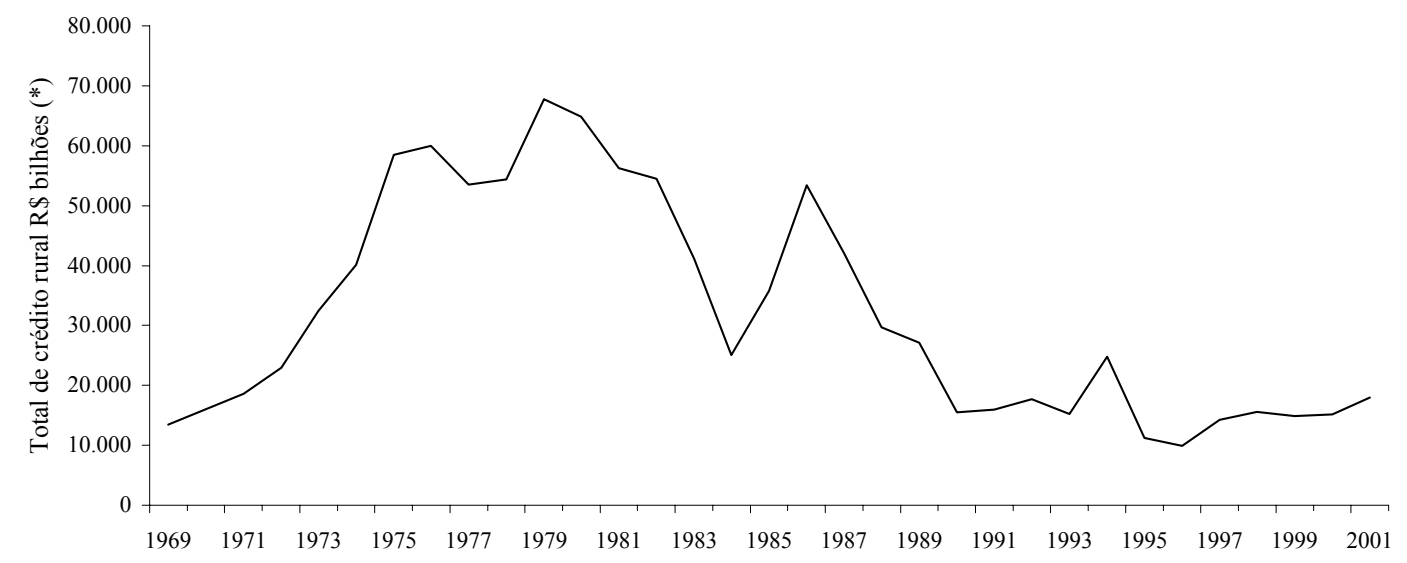

Figura 2 - Evolução do crédito rural no Brasil.

Fonte: Banco Central do Brasil (2001)

(*) IGP-DI índice médio anual (valores constantes em reais de 2001) 
A Figura 2 ilustra um volume de R\$ 18 bilhões de crédito rural concedido para o ano de 2001. Esse valor está bem abaixo do volume disponibilizado em 1986 quando o montante de crédito rural superou R\$ 54 bilhões. Para Gasques \& Conceição (2001) citando Faveret (2000), três características ocorridas na segunda metade dos anos 1990 tiveram impacto negativo sobre a oferta de crédito rural:

I) elevada inadimplência agrícola que produziu um bloqueio nos novos financiamentos para o setor. O autor cita o Banco do Brasil, que em dezembro de 1988 apresentava um volume de crédito em atraso e liquidação da ordem de $\mathrm{R} \$ 3,3$ bilhões, dos quais $\mathrm{R} \$ 3,1$ bilhões eram oriundos de financiamentos rurais e agroindustriais;

II) adesão do Brasil ao Acordo da Basiléia, resultando na implementação de normas mais rigorosas com o objetivo de reduzir e controlar o risco do sistema financeiro. Este fato gerou a criação de algumas medidas como:

i) definição de limites mínimos de capital para constituição dos bancos;

ii) criação de um Sistema Central de Risco de Crédito;

iii) redução de 12,5 para 9 vezes o patrimônio líquido como limite máximo para os empréstimos;

iv) regulamentação dos sistemas de controle internos; e

v) obrigatoriedade de adoção de sistemas de classificação de risco dos clientes.

III) finalmente o autor cita as mudanças nas estratégias bancárias nos últimos anos da década de 1990, com o objetivo de se reduzirem o risco e o custo dos empréstimos agropecuários. Dessa forma, os bancos, por meio de contratos formais ou de orientações informais, têm procurado 
repassar algumas de suas tarefas, como a seleção de produtores, definição de garantias e acompanhamento dos projetos financiados.

Apesar do volume de crédito rural não ter crescido nos últimos anos, algumas mudanças podem ser observadas. Dentre essas mudanças, observa-se uma maior participação do sistema financeiro privado no volume total de crédito rural. A Figura 3 ilustra a participação do sistema financeiro privado sobre o total.

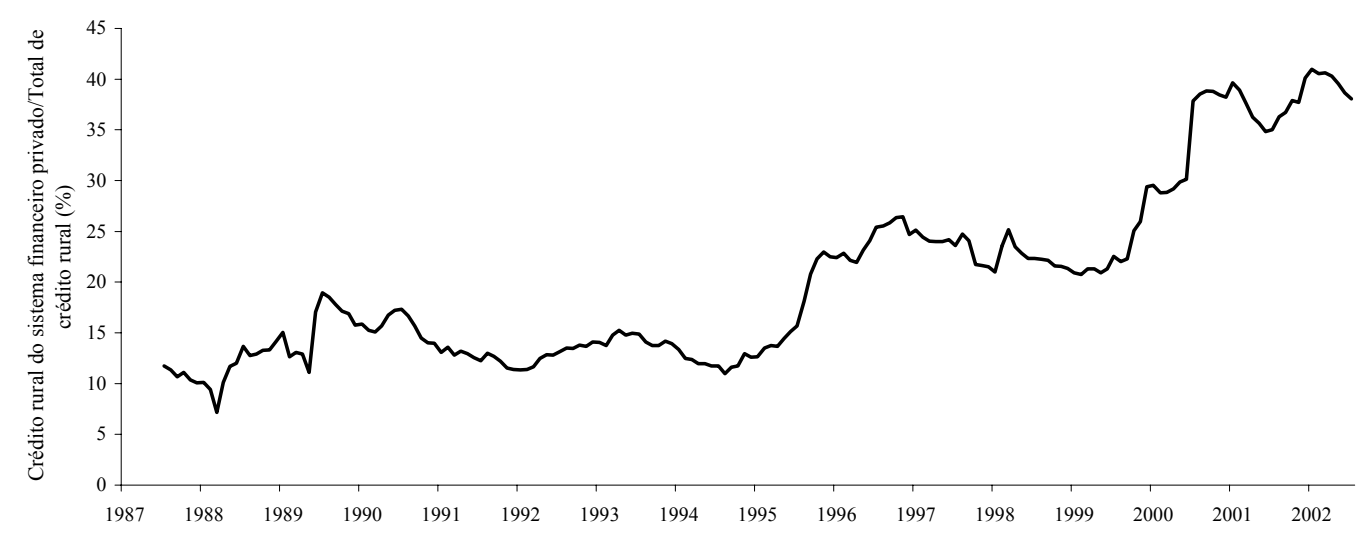

Figura 3 - Participação do sistema financeiro privado no volume total de crédito rural. Fonte: Banco Central do Brasil (2003)

A Figura 3 evidencia que as instituições financeiras privadas, ao final de 1995, participavam com menos de 13\% do volume total de crédito rural. Já em 2001 essa participação atingia cerca de $40 \%$. Este expressivo aumento na participação das instituições financeiras privadas se deve principalmente a imposição estabelecida pelo BACEN através da Resolução 2.293 (Anexo A) de junho de 1996. Essa Resolução determinou um aumento gradativo ao final de 1996, de forma que no início de 1997, as instituições financeiras deveriam aplicar, em crédito rural, $25 \%$ do saldo médio diário das rúbricas contábeis de recursos à vista sujeitos ao recolhimento compulsório. Esse percentual permanece atualmente inalterado.

Com o aumento da participação destas instituições, aumentou-se também a preocupação com o risco de inadimplência. No processo de quantificação de crédito 
existe a dificuldade de se medir a inadimplência de uma determinada classificação e sua volatilidade ao longo de um período. Isto, conseqüentemente dificulta a obtenção da distribuição de perdas do portfólio. O crédito rural apresenta, além destas dificuldades, algumas características particulares. Securato (2002), enfatiza que ao analisar elementos de riscos setoriais nas projeções econômico-financeiras que afetam o crédito, as produções agrícola e agropecuária podem ser divididas em duas categorias: produtores independentes e produtores vinculados à agroindústria/indústria, da qual recebem suporte técnico e financeiro. Dentre os principais riscos do setor primário e das indústrias vinculadas à estes, destacam-se:

I) fatores climáticos;

II) políticas governamentais;

III) atrasos nas liberações de recursos oficiais;

IV) dependência da indústria e de trade companies;

V) excesso de safra;

VI) problemas de armazenagem; e

VII) atrasos tecnológicos.

Fatores climáticos como a ocorrência de geadas ou estiagem podem provocar uma quebra de safra, aumentando o risco do empréstimo não ser pago. $\mathrm{O}$ excesso de safra em outros países também pode dificultar as exportações ou derrubar os preços no mercado interno, pelo desequilíbrio oferta/demanda.

A dependência de políticas governamentais relativas ao setor, concentradas, muitas vezes, em política creditícia, proporciona ao produtor a dificuldade de obtenção de preços mínimos de comercialização. Além disso, ocorrem atrasos nas liberações de recursos oficiais para investimento e custeio, muitas vezes liberados com taxas de juros elevadas. 
Outro item é a dependência, dos produtores, de adiantamentos da indústria e de trade companies. Quando estes adiantamentos não acontecem, o produtor descapitalizado não consegue iniciar sua produção. Pode-se citar também problemas de armazenagem, fazendo com que se perca, algumas vezes, parcela substancial da safra agrícola. Por fim, destaca-se o baixo poder de competitividade de alguns segmentos agrícolas e pecuários devido a atrasos tecnológicos.

\subsection{Classificação de clientes}

O processo de classificação de clientes elaborado pelos gerenciadores de carteiras indica o nível de risco que a organização está exposta caso conceda um crédito a estes clientes. A seguir é apresentada uma descrição do processo de classificação para que se possa entender quais são os principais aspectos considerados na atribuição da classificação associada ao cliente do portfólio de crédito rural, utilizado como estudo neste trabalho.

Para Securato (2000), classificar um crédito é, a partir de um conjunto de informações e de determinados parâmetros previamente selecionados, identificar em qual categoria de risco de crédito o cliente ativo ou potencial, seja pessoa física ou jurídica, se insere. O grau de risco, segundo o autor, é uma qualificação atribuída em função de indicadores financeiros combinados a informações de caráter qualitativo, indicando a severidade que o cliente deve ser tratado, tanto no momento do estabelecimento dos limites de crédito ou de aprovação de uma operação específica quanto no posterior gerenciamento do risco.

As agências de rating assumiram grande importância na administração de risco de crédito, classificando grandes empresas quanto à sua capacidade futura de pagamento de juros e do principal. Baseado no histórico de inadimplência das empresas e do seu perfil, as agências atribuem uma nota a cada empresa. Com isso indicam ao investidor a probabilidade de uma determinada empresa se tornar inadimplente. 
A base de dados histórica, utilizada pelas agências internacionais de rating para definir a probabilidade de inadimplência associada a cada classificação, nem sempre é possível de se obter, principalmente para empresas localizadas em mercados que não possuem a "cultura de classificação", como é o caso do Brasil. Dessa forma, a maioria das instituições financeiras brasileiras passou a elaborar um sistema próprio de classificação de clientes.

Preocupado com a transparência do sistema financeiro nacional e com os riscos a que as suas instituições estavam expostas, o BACEN, em de 21 de dezembro de 1999, elaborou a Resolução 2682 (Anexo B), determinando nove graus de severidade para classificação em ordem crescente de risco e percentuais mínimos para constituição de provisão para créditos de liquidação duvidosa (PDD). Antes desta medida adotada pelo BACEN, cada instituição fazia o provisionamento de acordo com seus critérios internos, o que não proporcionava transparência ao mercado. Os nove graus de classificação, também denominados de níveis, apresentam uma severidade conforme ilustra a Tabela 1 .

Tabela 1. Percentual mínimo de provisionamento por classificação da operação, em \%.

\begin{tabular}{lccccccccc}
\hline Item & AA & A & B & C & D & E & F & G & H \\
\hline Provisão & 0 & 0,5 & 1 & 3 & 10 & 30 & 50 & 70 & 100 \\
\hline
\end{tabular}

Fonte: Banco Central do Brasil (1999)

O BACEN também determina que uma operação com atraso entre 15 e 30 dias, por exemplo, seja, no mínimo, classificada como "B". Isto não significa que a instituição não possa ter um cliente classificado como "B” pelo seu modelo proprietário, sem que este tenha qualquer atraso. A classificação determinada pelo atraso da operação ocorre gradativamente na medida em que este atraso aumenta, conforme ilustra a Tabela 2. 
Tabela 2. Classificação correspondente ao atraso da operação, em dias.

\begin{tabular}{lccccccccc}
\hline Item & AA & A & B & C & D & E & F & G & H \\
\hline Atraso & - & - & $15-30$ & $31-60$ & $61-90$ & $91-120$ & $121-150$ & $151-180$ & $>180$ \\
\hline
\end{tabular}

Fonte: Banco Central do Brasil (1999)

Analisando-se a Tabela 2, observa-se que uma operação de crédito com atraso entre 91 e 120 dias, por exemplo, deve ser classificada no nível "E". Pela Tabela 1, uma operação classificada como "E" necessita de um provisionamento de $30 \%$ de seu valor total. Isso significa que a instituição deve manter uma reserva de $30 \%$ do valor de todas as operações do seu portfólio classificadas como "E". Nota-se que depois de decorridos 180 dias de atraso, a operação vai estar classificada como "H" e terá $100 \%$ de provisionamento.

A instituição financeira detentora do crédito é responsável pela classificação no nível de risco correspondente, classificação essa efetuada com base em critérios consistentes e verificáveis, amparada por informações internas e externas, contemplando os seguintes aspectos:

I) em relação ao devedor e seus garantidores:

i) situação econômico-financeira;

ii) grau de endividamento;

iii) capacidade de geração de resultados;

iv) fluxo de caixa;

v) administração e qualidade de controles;

vi) pontualidade e atrasos nos pagamentos;

vii) contingências;

viii) setor de atividade econômica; e

ix) limite de crédito.

II) em relação a operação: 
i) natureza e finalidade da transação;

ii) características das garantias, particularmente quanto a suficiência e liquidez; e

iii) valor.

As instituições financeiras podem definir pesos diferentes para cada um dos aspectos citados acima. Uma instituição mais conservadora pode considerar fundamental a apresentação de uma garantia para concessão do crédito, penalizando a classificação da operação caso o cliente não possua uma garantia com alta liquidez. Uma outra instituição financeira pode considerar essencial o tipo de administração utilizado na empresa tomadora de risco, atribuindo uma classificação melhor de acordo com a qualidade dos controles que a empresa possui. Além disso, outros aspectos particulares de cada instituição são considerados na construção de modelos proprietários de classificação. No entanto, a classificação de clientes feita pelo modelo proprietário deve convergir para um dos níveis definidos pelo BACEN. Estes modelos proprietários possuem características que podem resultar em classificações diferenciadas para uma mesma empresa com risco em duas instituições distintas. Dessa forma, as instituições financeiras são obrigadas a fornecer seus critérios de classificação de clientes e sua equivalência ao nível definido pelo BACEN, bem como o montante provisionado em cada nível.

\subsection{Valor em risco de um ativo (VaR)}

O conceito de VaR (Value at Risk) vem sendo difundido desde de 1994, com o objetivo de quantificar o risco de mercado. Sua utilização passou a ser empregada com maior intensidade após uma série de entidades financeiras internacionais, como Condado de Orange, Barings, Metallgesellschaft, Showa Shell e Daiwa, perderem bilhões de dólares nos mercados financeiros. Mais recentemente, este conceito passou a fazer parte do vocabulário dos gestores de portfólio de crédito.

Para o cálculo do VaR de um ativo são necessários, basicamente, seu valor de mercado e a volatilidade do desvio padrão de seu valor de mercado. Estes conceitos, 
quando aplicados a uma carteira de empréstimos, apresentam alguns problemas, pois, como os empréstimos não são negociáveis, seu valor de mercado não é diretamente observável e os retornos destes empréstimos apresentam significativa assimetria.

Jorion (1997), define o $V a R$ como sendo um método de mensuração de risco que utiliza técnicas estatísticas padrões, comumente usadas em outras áreas técnicas. Para o autor, o $V a R$ mede a pior perda esperada ao longo de determinado intervalo de tempo, sob condições normais de mercado e dentro de determinado nível de confiança. De maneira semelhante, Souza (2000) define o VaR como sendo a perda máxima esperada da carteira, a um nível de significância de $\alpha \%$ (ou nível de confiança de 1- $\alpha$ ), dentro de um horizonte de tempo determinado. É importante observar que se trata de uma medida monetária, dado que a variável aleatória, nesse caso, é a variação de valor da carteira.

Por outro lado, Duarte (2000), enfatiza que o VaR de uma carteira de investimentos é uma medida do valor da depreciação que uma carteira pode sofrer durante um certo horizonte de tempo, com certa probabilidade. A grande motivação para o uso do conceito de $V a R$ é que este integra o risco de todo o ativo/passivo em uma única medida numérica, resumindo o risco total, por exemplo, de um banco para acompanhamento de sua diretoria. A grande deficiência do conceito de $V a R$ é que risco é conceito multidimensional, logo a integração do risco total de uma instituição em uma única medida numérica requer simplificações.

Dentre os principais métodos apresentados em literatura para obtenção do VaR, Bignotto (2002) ressalta que esses podem ser categorizados em três grupos:

I) Aproximação por uma distribuição paramétrica conhecida, onde o cálculo do $V a R$, considera que a distribuição dos retornos do portfólio segue uma distribuição de probabilidade paramétrica apropriada, onde o tratamento analítico seja relativamente acessível. Para o autor, um exemplo desse método é caracterizado pela obtenção do $V a R$ através 
da distribuição normal, cujos parâmetros são a esperança (média) e a variância;

II) Método não-paramétrico fundamentado em série histórica, mais conhecido pelo mercado como simulação histórica, é a mais simples forma de cálculo do $V a R$, segundo o autor, pois requer relativamente poucos recursos técnicos, como instrumentais estatístico e computacional. Consiste basicamente em replicar os resultados históricos de retorno dos ativos para projetar o futuro, ou seja, reproduz as variações passadas nos preços e nas taxas para o futuro. Para Linsmeier \& Pearson (1996), o método não paramétrico tende a ser mais confiável conforme se aumenta o número de observações e de cenários utilizados. No entanto, Bignotto (2002), coloca que esta afirmação só será verdadeira se o mercado não sofrer impactos suficientes a ponto de modificar o comportamento estatístico das variações diárias; e

III) Simulação Monte Carlo, cuja metodologia possui similaridade com método não-paramétrico. No entanto, as variações futuras são simuladas a partir de distribuição de probabilidade, cujos parâmetros são estimados a partir de séries históricas. Para esta simulação utilizase um gerador de números aleatórios a partir da distribuição desejada (simulador Monte Carlo).

O VaR pode ser entendido como um valor crítico de perdas, estabelecido em uma distribuição de retornos esperados para um portfólio de ativos financeiros no qual não se espera ser igualado ou superado com uma determinada probabilidade crítica em um período de tempo tomado como base. O conceito VaR procura capturar os eventos que ocorrem nas extremidades das caudas das distribuições de retornos dos portfólios. 
A aplicação do conceito de $V a R$ para o caso de empréstimos não negociáveis, isto é, sem mercado secundário, como é o caso brasileiro, provoca alguns problemas imediatos como:

I) valor do empréstimo não é observável diretamente porque a maioria dos empréstimos não são negociáveis;

II) como não se observa o valor do empréstimo, não há como calcular o desvio-padrão; e

III) a aproximação de uma distribuição normal para retornos de alguns ativos negociáveis torna-se grosseira quando aplicada à distribuição de empréstimos.

Nos últimos dez anos, segundo Securato (2002), as instituições financeiras vem promovendo esforços no desenvolvimento e implementação de uma variedade de modelos sofisticados de $V a R$, com o objetivo de modelar o risco de mercado das carteiras. No entanto, o próximo passo, segundo o autor, é o desenvolvimento de modelos similares ao $\mathrm{VaR}$ para risco de crédito.

\subsection{Capital econômico alocado $(C E A)$}

O capital econômico alocado (CEA) determina o montante de capital necessário para a cobertura de eventuais perdas com crédito. A determinação destas perdas, chamadas de inesperadas, utiliza-se de metodologias que necessitam previamente a determinação do $V a R$ do portfólio de crédito em estudo.

Para Smithson \& Hayt (2003), a alocação de capital abrange hoje todas as atividades relacionadas ao gerenciamento do capital de um banco e à mensuração de seu desempenho, interferindo na maneira como a instituição precifica interna e externamente seus serviços, na remuneração de seus empregados e no sucesso da criação de valores para os acionistas. 
A definição de $C E A$ é importante quando associada à administração de risco de crédito. A Figura 4 exibe a função de densidade de probabilidade para perdas de crédito de um portfólio. Esta função de densidade permite a computação da probabilidade das perdas com crédito excederem a um nível escolhido, isto é, o valor em risco da carteira.

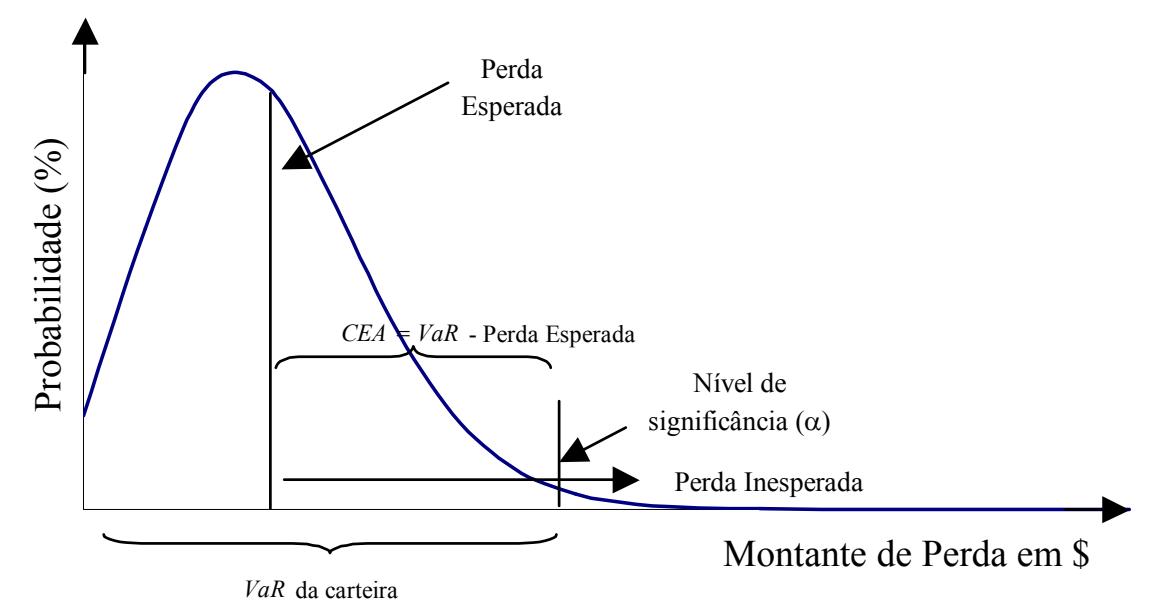

Figura 4 - Distribuição de perdas de uma carteira de empréstimos.

Fonte: Prado et al. (2000)

As perdas esperadas ilustradas na Figura 4 podem ser entendidas como o impacto financeiro antecipado de perdas com crédito. Perdas esperadas podem também ser vistas como o custo previsível de conceder crédito. As perdas esperadas devem ser cobertas pela provisão para devedores duvidosos.

Perdas inesperadas, por outro lado, estão associadas à incerteza em relação às perdas com crédito. Um objeto de interesse para metodologias de medição de risco de crédito é a estimação das perdas inesperadas. Conforme pode ser visto na Figura 4, as perdas inesperadas são aquelas além das perdas esperadas. Fixando-se um nível de significância $(\alpha)$, a taxa de insolvência objetivada equivale ao nível máximo de perdas (perdas esperadas mais perdas inesperadas) cuja probabilidade acumulada não exceda o nível de significância adotado. Dessa forma, o CEA pode ser definido como o montante de patrimônio líquido necessário para cobrir qualquer valor de perda entre as perdas 
esperadas e a taxa de insolvência objetivada. Seu valor é calculado pela diferença entre o valor em risco da carteira $(\operatorname{VaR})$, com determinado nível de significância $(\alpha)$ e a perda média esperada.

O volume de capital, ou $C E A$, necessário a um banco para proteger-se contra perdas é determinado pelo risco de sua carteira de empréstimos. No contexto da distribuição das perdas com crédito, as reservas do banco são determinadas pelas perdas previstas (esperadas) e imprevistas (inesperadas) da carteira. Algumas instituições financeiras utilizam um múltiplo da perda prevista para determinar a perda imprevista, de maneira que a probabilidade de que as perdas superem o capital é extremamente remota. Outras instituições já se utillizam de modelos quantitativos que determinam o montante de capital necessário para neutralizar as perdas (esperadas e inesperadas) com crédito. Esses modelos devem atender as necessidades impostas pelo Novo Acordo da Basiléia. Uma descrição mais detalhada de alguns modelos existentes é feita no ítem 2.8

Nos casos analisados por Caouette et al. (1999), o processo de alocação de capital era eficaz quando o mesmo se caracterizava pelos seguintes elementos:

I) é parte de um processo disciplinado de administração;

II) seu foco é maximizar o valor para o acionista;

III) condiz com a estrutura de gerenciamento de risco corporativo;

IV) é abrangente (ou seja, inclui todos os riscos e todas as atividades);

V) aplica análises tanto quantitativas quanto qualitativas;

VI) é bem compreendido, controlado de maneira eficaz e comunicado internamente; e

VII) é adotado como ferramenta com credibilidade (uma fonte de informações) pelos tomadores de decisão. 
A instituição deve dispor de um processo disciplinado de administração de risco, calculando o capital econômico periodicamente de forma que este não seja excessivo nem escasso, mas que realmente cubra as perdas inesperadas dentro do nível de significância adotado. Seu foco essencial deve ser na maximização do valor para o acionista, ajustando o retorno ao risco de crédito envolvido.

A alocação de capital deve ser abrangente, incluindo todos os riscos envolvidos nas atividades da instituição financeira. Dessa forma, deve-se possuir uma estrutura que permita identificar todos esses riscos, proporcionando um gerenciamento de risco corporativo. Deve-se aplicar análises quantitativas e qualitativas na determinação do montante de capital, de modo que os gerenciadores estejam integrados e compreendam todas as variáveis envolvidas no processo. Além disso, esses gerenciadores devem utilizar a alocação de capital como uma das fontes de informações, para determinar se uma operação deve ou não ser realizada em função do impacto que resultaria no montante de capital econômico.

\subsection{Retorno ajustado ao risco nas operações de crédito bancário (RAROC)}

O conceito de RAROC (Risk Adjusted Return on Capital), permite aos gerenciadores de carteira determinar qual o retorno de um determinado investimento ponderado pelo risco. Quando este retorno é maior que a taxa de atratividade, o investimento passa a ser viável. Este tipo de análise tem sido discutido e aplicado em carteiras de crédito de forma a ajustar seu retorno aos riscos envolvidos nas operações de empréstimos, possibilitando a tomada de decisões de investimento e precificação de ativos mais precisas.

Segundo Jorion (1997), o sistema RAROC, introduzido no final da década de 1970, foi inspirado na necessidade de ajustar o lucro do trader ao risco. Dessa forma, o RAROC ajusta os lucros em relação ao capital no risco, definido como o montante necessário para cobrir 99\% (nível de confiança depende de cada instituição) da maior perda possível em um ano. De maneira semelhante, Bastos (2000), ilustra que o RAROC estabelece alocação de capital para transações ou divisões de uma instituição financeira, 
igual à perda máxima esperada durante o período de um ano, com um nível de significância estatística de 99\% (antes da incidência de imposto de renda).

De acordo com Saunders (1999), a recente onda entre bancos e instituições financeiras para adoção de formas privativas de RAROC pode ser explicada pela exigência dos acionistas por desempenho melhorado e pelo crescimento de conglomerados de instituições financeiras construídos em torno de unidades de negócios separados. Esses acontecimentos fizeram com que fosse criada uma medida de desempenho comparável entre unidades de negócio, dado que o capital do banco é tanto caro quanto limitado.

Os modelos de RAROC têm sido utilizados como principal ferramenta para as seguintes decisões financeiras:

I) alocação de capitais;

II) avaliação de desempenho econômico;

III) determinação de spreads diferenciados, compatíveis com as perdas esperadas;

IV) administração ativa de portfólios; e

V) otimização de portfólios (maximização de RAROC).

A utilização na alocação de capitais pode ser feita através da determinação do impacto no RAROC total da instituição financeira. Essas metodologias de RAROC medem o desempenho econômico da instituição através da comparação entre seu lucro econômico e o seu custo de capital. No contexto das operações de crédito, esse tipo de metodologia exige que os empréstimos sejam realizados somente quando forem capazes de agregar valor econômico para a instituição. Assim, é possível determinar qual spread deve ser cobrado de um empréstimo para que este agregue valor econômico à instituição. 
A equação do RAROC é dada por:

$$
\text { RAROC }=\frac{L E}{C E A}
$$

e,

$$
L E=S+T A-P E-O C O
$$

onde:

$L E=\quad$ lucro econômico: mede a lucratividade da operação;

$S=\quad$ spread: reflete as receitas diretas do empréstimo, que é a diferença entre o custo de captação e a taxa de juros cobrada pelo empréstimo;

$T A=\quad$ taxas adicionais: são todas e quaisquer taxas cobradas do cliente, que venham a incrementar as receitas de operação;

$P E=\quad$ perdas esperadas: correspondem ao valor projetado das perdas com crédito, com base em modelos quantitativos;

$O C O=$ outros custos operacionais: são custos diretamente atribuídos à operação, relativos à origem e ao monitoramento do empréstimo.

Para Saunders (1999), o numerador na fórmula do RAROC é alguma medida de lucro ajustada ao longo de um período futuro ou um período anterior. O denominador é uma medida da perda inesperada de capital econômico em risco como resultado daquela atividade.

O CEA, no denominador da fórmula do RAROC, definido anteriormente no item 2.6, pode ser ilustrado como sendo o montante de capital necessário para cobrir perdas inesperadas com crédito durante um certo período de tempo. Uma vez calculado o RAROC de um empréstimo, ele é comparado com o custo de oportunidade do 
acionista. Os empréstimos capazes de superar o custo de oportunidade e de adicionar valor para a instituição são aceitos.

A grande dificuldade enfrentada por uma instituição financeira na implantação do modelo de RAROC não é técnica, mas sim de sistemas. O RAROC exige que se tenha acesso a um banco de dados contendo dados históricos de perdas e recuperações de crédito.

A partir do exemplo de Bastos (2000), propõe-se um portfólio hipotético de crédito com as seguintes informações para o horizonte de um ano:

Valor do Portfólio $=\mathrm{R} \$ 2.000 .000$

$S=4 \% * \mathrm{R} \$ 2.000 .000=\mathrm{R} \$ 80.000$

$T A=0,05 \% * \mathrm{R} \$ 2.000 .000=\mathrm{R} \$ 1.000$

$P E=\mathrm{R} \$ 60.000$

$O C O=\mathrm{R} \$ 5.000$

Percentil de $99 \%=\mathrm{R} \$ 140.000$

$C E A=\mathrm{R} \$ 140.000-\mathrm{R} \$ 60.000=\mathrm{R} \$ 80.000$

Utilizando a fórmula definida na equação (1), o RAROC deste portfólio é calculado como:

$$
\mathrm{RAROC}=(\mathrm{R} \$ 80.000+\mathrm{R} \$ 1.000-\mathrm{R} \$ 60.000-\mathrm{R} \$ 5.000) / 80.000=20 \% \text { ao ano }
$$

Neste caso, se a taxa de corte (custo de oportunidade) do banco for de $18 \%$ ao ano, o portfólio estaria remunerando adequadamente o capital dos acionistas. 


\subsection{Quantificação do risco de crédito}

Algumas instituições avaliam o crédito de forma individual, de acordo com as necessidades e capacidades de seus clientes, preocupando-se mais com o relacionamento com o cliente e o lucro gerado para o banco em sua operação, do que com o efeito sobre toda a carteira de empréstimos do banco. Este tipo de abordagem tem levado algumas instituições a resultados ruins nas últimas décadas, fazendo com que estas instituições procurassem novas técnicas de mensuração de risco.

Metodologias para mensuração de risco de mercado tem sido utilizadas na mensuração do risco de crédito, apesar da distribuição dos ganhos/perdas não ser a mesma para o mercado e o crédito. Os gerenciadores de carteira consideram que os retornos típicos de mercado têm distribuição esperada normal, enquanto que os retornos de crédito são limitados superiormente. A Figura 5 ilustra uma comparação do retorno devido ao crédito com o retorno de um portfólio de mercado.

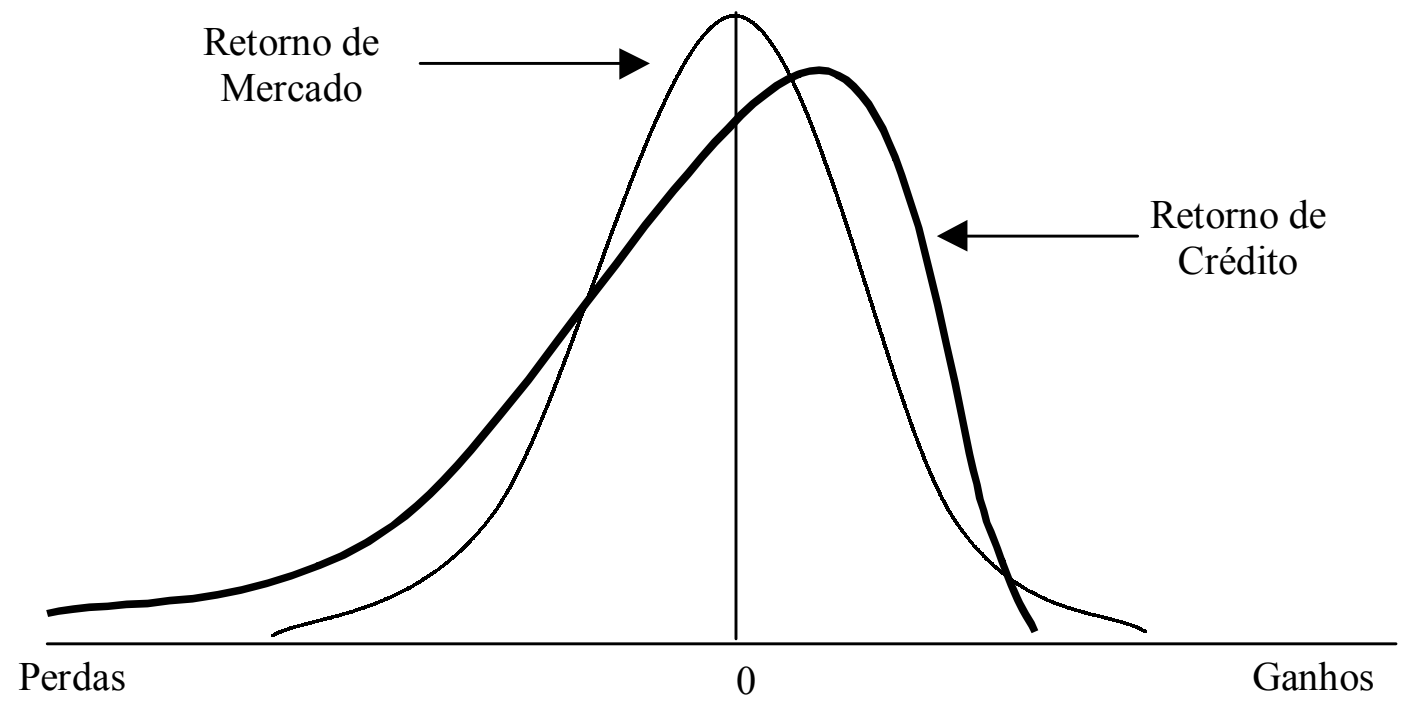

Figura 5 - Comparação entre retorno de mercado e retorno de crédito.

Fonte: JPMorgan (1997) 
Para a mensuração do risco de mercado, a literatura destaca quatro metodologias básicas:

I) marcação a mercado (MTM);

II) inadimplência;

III) macroeconômicas fatoriais; e

IV) baseadas em Teoria das Opções.

Metodologias que utilizam MTM necessitam de mercados secundários líquidos. Isso não é observável para empréstimos no Brasil, tanto para carteiras de varejo quanto para as de atacado. Por sua vez, modelos macroeconômicos fatoriais requerem uma grande quantidade de dados para todos os fatores macroeconômicos selecionados. Quando ocorrem "eventos atípicos” na economia, pode-se ter problemas de modelagem devido a indisponibilidade de dados.

Modelos baseados em teoria das opções necessitam de mercado local de ações e opções. O fato de muitas empresas, presentes nas carteiras de crédito, não serem negociadas no mercado local, dificulta a utilização deste tipo de metodologia. Já as metodologias de inadimplência são mais adequadas para exposições que serão mantidas na carteira até o vencimento ou por períodos longos.

Alguns autores destacam que os principais modelos adaptados para avaliação de risco de crédito são: Credit Metrics apresentado pelo JP Morgan em 1997, o CreditRisk+ apresentado pelo CSFP em 1997, o Credit Portfolio View apresentado pela Mckinsey and Co. em 1997 e o modelo KMV apresentado pela KMV Corporation em 1989.

Para Pereira (1998), algumas dificuldades são enfrentadas pelos bancos para a utilização destes modelos: 
I) implantação e operacionalização de sistemas de quantificação e precificação de risco de crédito;

II) falta de utilização de derivativos de crédito; e

III) dificuldades na implantação de algum sistema de $V a R$ na área de crédito que integrado com o $V a R$ dos demais ativos, represente o $V a R$ da corporação.

A estimação do $C E A$ de uma carteira de crédito requer a obtenção da distribuição de probabilidade de suas perdas. Por sua vez, a estimação da distribuição das perdas da carteira requer algumas hipóteses probabilísticas a respeito das variáveis de risco básicas. Dependendo do tipo de modelagem é necessário analisar questões referentes a facilidade de implementação e operacionalização dos sistemas que proporcionem formas de precificação de operações de crédito.

A implantação de um sistema de $V a R$ na área de crédito está sendo realizada lentamente pelas grandes instituições financeiras no Brasil, mas a integração com o $V a R$ dos demais ativos ainda precisa ser estruturada. Além disso, o mercado de derivativos de crédito ainda está em fase de regulamentação pelos órgãos financeiros. Dentro deste contexto, faz-se necessário uma descrição mais detalhada dos modelos utilizados na quantificação do risco de crédito.

\subsubsection{O modelo Credit Metrics}

O Credit Metrics, apresentado em 1997 pelo JP Morgan, concentra o problema na metodologia para determinação das probabilidades condicionais de transformação da qualidade de um crédito dado. A partir dessas probabilidades, conforme Securato (2002), são estabelecidas as correlações entre os créditos e em seguida calcula-se o valor em risco da carteira de crédito, ou seja, a perda que se pode ter da carteira de crédito por variações das taxas de mercado. Para o autor, o modelo Credit Metrics tem o intuito de administrar o risco total das carteiras de crédito através 
da metodologia do VaR. Os dois benefícios da metodologia do Credit Metrics são, segundo o autor:

I) a quantificação do valor em risco devido ao crédito; e

II) do limite de crédito baseado no risco.

Para utilização desta metodologia são necessárias algumas premissas como dados de classificação de empresas e o valor de mercado do crédito concedido. Tudo isso, supondo que exista um mercado secundário líquido para empréstimos, o que não ocorre no Brasil. Além disso, esta metodologia exige que se tenha um histórico que permita dizer qual a probabilidade de um determinado empréstimo com classificação “boa" migrar para uma classificação "ruim" dentro de um determinado período de tempo.

A Figura 6 ilustra, de forma detalhada, a proposta de avaliação de risco de crédito encontrada no Credit Metrics para vários ativos.

Exposições

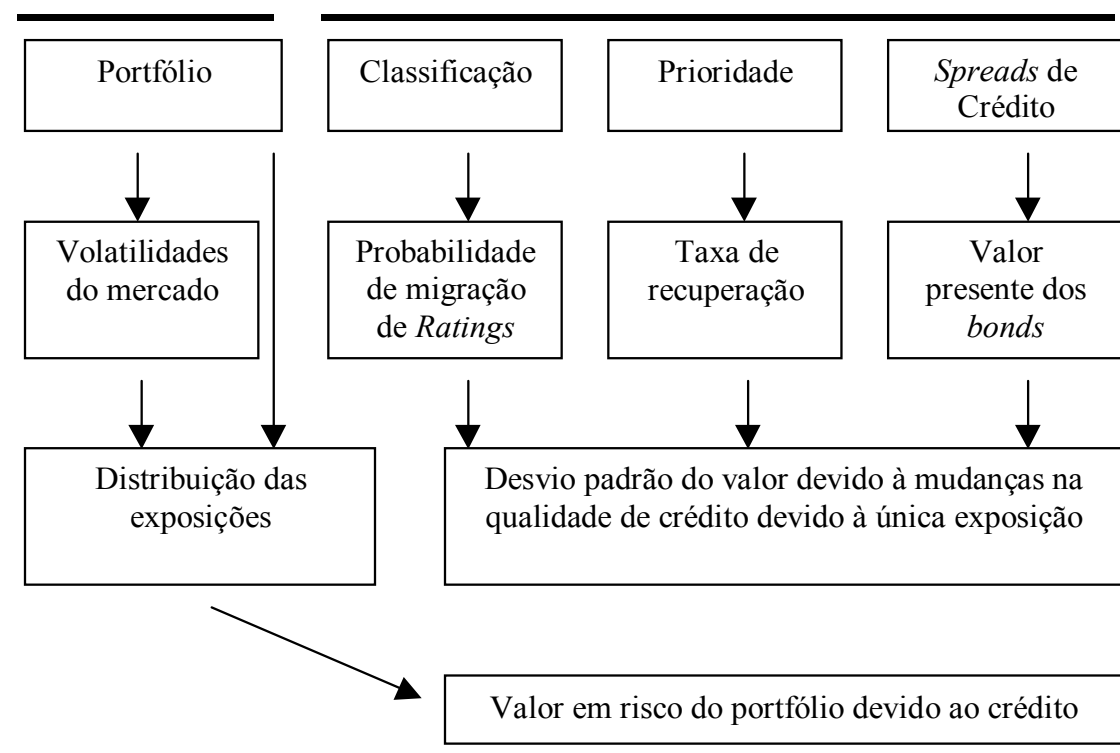

\section{Correlações}

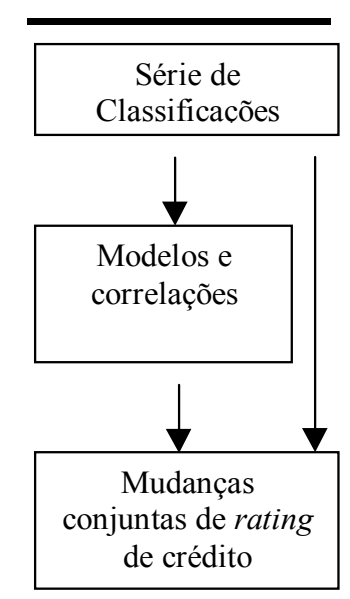

Figura 6 - Processo de determinação do $V a R$ de um portfólio devido ao crédito.

Fonte: JPMorgan (1997) 
Na primeira parte da Figura 6 tem-se o cálculo do $V a R$ de crédito de uma simples exposição; na segunda parte têm-se as distribuições das exposições; na terceira parte, as mudanças conjuntas de rating de crédito e na quarta parte, o cálculo do $V a R$ de crédito do portfólio.

Maiores detalhes do processo utilizado no Credit Metrics podem ser encontrados em Abe (2002), onde o autor considera os seguintes passos para o cálculo do $V a R$ de crédito de um portfólio.

\section{Passo 1: Matriz de migração}

É necessário construir a matriz de migração de classificação de cada empresa para o próximo ano, ou seja, para o tomador de empréstimo necessita-se determinar quais os possíveis estados que este tomador poderá migrar. Por exemplo, um tomador com classificação AA têm $90 \%$ de chance de permanecer em AA, $8 \%$ de chance de migrar para a classificação A e $2 \%$ de chance de migrar para a classificação BB. Este procedimento deve ser extrapolado para todo o portfólio, analisando a correlação entre os ativos, de forma a obter a probabilidade conjunta de dois ou mais ativos migrarem para outra classificação.

\section{Passo 2: Cálculo da correlação entre os ativos}

Segundo Abe (2002), o Credit Metrics calcula as correlações entre os ativos através de modelos mutifatoriais de retornos de ações para tomadores de empréstimos. Estas correlações entram no cálculo das probabilidades de migração em conjunto descritas no passo anterior.

\section{Passo 3: Valores dos empréstimos}

Após o cálculo das probabilidades de migração em conjunto, é possível obter as combinações dos valores do portfólio prováveis, calculando o valor da obrigação em cada classificação ao final de um ano. 
Para Aragão et al. (2002), o modelo Credit Metrics é baseado na abordagem de risco de spread, exigindo uma marcação a mercado da carteira de crédito. O modelo procura estabelecer qual será a perda de uma carteira de crédito devido a alterações na classificação de crédito dos devedores e eventuais ocorrências de inadimplências. Os autores ressaltam que o valor de mercado do empréstimo e de sua volatilidade, exigidos no cálculo do Credit Metrics não são diretamente observáveis no mercado, sendo assim utilizam-se dados sobre classificação de crédito do devedor, as probabilidades de que esta classificação seja alterada ao longo do tempo, os índices de recuperação de cada faixa de classificação e os spreads do mercado secundário. Isto possibilita a determinação de estimativas de valor de mercado e de sua volatilidade necessários ao cálculo do valor em risco de um devedor ou da carteira de crédito.

Securato (2002), apresenta um exemplo de cálculo da metodologia do Credit Metrics conforme ilustrado a seguir. Utilizando como base para a taxa livre de risco o CDI (certificado de depósito interbancário) a 18\% ao ano, estima-se as taxas que deveriam ser oferecidas por classificação, conforme a Tabela 3.

Tabela 3. Taxas de retornos com crédito por classificação, dado CDI a 18\% a.a., em \%.

\begin{tabular}{cccccccc}
\hline AAA & AA & A & BBB & BB & B & CCC & Inadimplente \\
\hline 18,4 & 18,7 & 19,4 & 20,9 & 23,8 & 29,5 & 41,0 & 4,5 \\
\hline
\end{tabular}

Fonte: Securato (2002)

Utilizando-se, como exemplo, as probabilidades de um título migrar de classificação de um ano para outro, tem-se a Tabela 4. 
Tabela 4. Matriz de migração, em \%.

\begin{tabular}{lcccccccc}
\hline De/Para & AAA & AA & A & BBB & BB & B & CCC & Inadimplente \\
\hline AAA & 95 & 3 & 2 & & & & & \\
AA & 1 & 90 & 4 & 3 & 2 & & & \\
A & 1 & 2 & 85 & 5 & 4 & 2 & 1 & \\
BBB & 1 & 2 & 3 & 80 & 5 & 4 & 3 & 4 \\
BB & 1 & 2 & 3 & 4 & 75 & 6 & 5 & 9 \\
B & & 1 & 2 & 3 & 4 & 70 & 11 & 25 \\
CCC & & & 1 & 2 & 3 & 4 & 65 & \\
\hline
\end{tabular}

Fonte: Securato (2002)

O valor presente do título de $\mathrm{R} \$ 100,00$ que vence no Ano 3, descontado as taxas de sua classificação, pode ser ilustrado na Tabela 5.

Tabela 5. Marcação a mercado de um título com vencimento no Ano 3, em R\$.

\begin{tabular}{lcccccccc}
\hline Ano & AAA & AA & A & BBB & BB & B & CCC & Inadimplente \\
\hline Ano 1 & 71,38 & 70,95 & 70,10 & 68,44 & 65,29 & 59,61 & 50,27 & 4,31 \\
Ano 2 & 84,49 & 84,23 & 83,72 & 82,73 & 80,80 & 77,21 & 70,90 & 4,50 \\
\hline
\end{tabular}

Fonte: Securato (2002)

Utilizando-se os possíveis caminhos que o título poderá percorrer até chegar aos R\$100,00, são calculados os retornos esperados na Tabela 6. 
Tabela 6. Taxas de retorno esperado para cada classificação do título.

\begin{tabular}{lccccccccc}
\hline De/Para & & AAA & AA & A & BBB & BB & B & CCC & Inadimplente \\
\hline \multirow{2}{*}{ AAA } & Ano 1/2 (R\$) & 84,49 & 84,23 & 83,72 & 82,73 & 80,80 & 77,21 & 70,90 & 4,50 \\
AA & 71,38 & $18,4 \%$ & $18,0 \%$ & $17,3 \%$ & $15,9 \%$ & $13,2 \%$ & $8,2 \%$ & $-0,7 \%$ & $-93,7 \%$ \\
A & 70,95 & $19,1 \%$ & $18,7 \%$ & $18,0 \%$ & $16,6 \%$ & $13,9 \%$ & $8,8 \%$ & $-0,1 \%$ & $-93,7 \%$ \\
BBB & 70,10 & $20,5 \%$ & $20,2 \%$ & $19,4 \%$ & $18,0 \%$ & $15,3 \%$ & $10,1 \%$ & $1,1 \%$ & $-93,6 \%$ \\
BB & 68,44 & $23,5 \%$ & $23,1 \%$ & $22,3 \%$ & $20,9 \%$ & $18,1 \%$ & $12,8 \%$ & $3,6 \%$ & $-93,4 \%$ \\
B & 65,29 & $29,4 \%$ & $29,0 \%$ & $28,2 \%$ & $26,7 \%$ & $23,8 \%$ & $18,3 \%$ & $8,6 \%$ & $-93,1 \%$ \\
CCC & 59,61 & $41,7 \%$ & $41,3 \%$ & $40,5 \%$ & $38,8 \%$ & $35,5 \%$ & $29,5 \%$ & $18,9 \%$ & $-92,5 \%$ \\
\hline
\end{tabular}

Fonte: Securato (2002)

Combinando-se as probabilidades de transição, com os retornos esperados, tem-se a Tabela 7 com os retornos médios e as volatilidades por classificação.

Tabela 7. Retorno médio e volatilidade por classificação, em \%.

\begin{tabular}{lcc}
\hline Classificação & Retorno médio & Volatilidade \\
\hline AAA & 18,3 & 0,2 \\
AA & 18,5 & 0,8 \\
A & 18,9 & 2,4 \\
BBB & 17,7 & 16,2 \\
BB & 18,4 & 23,1 \\
B & 18,2 & 35,1 \\
CCC & 9,8 & 58,5 \\
\hline
\end{tabular}

Fonte: Securato (2002)

Com isso pode-se calcular a composição da carteira de crédito que maximize o retorno. 
Observa-se que para o exemplo ilustrado por Securato (2002), foram feitas considerações de probabilidades de transição dos títulos em cada ano, além da estimativa de valor do título ao final do ano.

A utilização do modelo Credit Metrics para o cálculo do VaR do portfólio, possui a limitação evidenciada por Duarte (2000), onde o Credit Metrics necessita de um provedor de classificações confiável e compatível, com dados sincronizados no que se refere a eventos de inadimplência. Apesar do fato de algumas instituições no Brasil estarem trabalhando rapidamente de modo a superar essa dificuldade, acredita-se que um período de adaptação seja necessário, de forma a conciliar as classificações internas das instituições com as que estão sendo tornadas públicas. Além disso, não existe um mercado secundário para empréstimos no Brasil, fazendo com que esta metodologia de quantificação de risco de crédito ainda seja utilizada apenas de forma acadêmica.

Saunders (1999), evidencia algumas questões técnicas na aplicação do modelo Credit Metrics. Por exemplo, ao se utilizar uma matriz de migração de classificação, ocorre a suposição de que as probabilidades de alteração seguem um processo de Markov estável, o que significa que a probabilidade de um empréstimo mudar para qualquer estado específico durante um determinado período, independe de qualquer resultado no período passado. Outra questão é a utilização de uma única matriz de alteração de classificação, pressupondo que estas alterações de classificação não diferem entre distintos tipos de tomadores, como por exemplo empresas industriais versus bancos. Além disso, não considera variações ao longo do tempo, sugerindo que importantes fatores setoriais, de países e de ciclos de negócios não promovam alterações de classificação.

\subsubsection{O modelo KMV}

O modelo KMV é um método baseado no modelo de Merton (1974), o qual foi adaptado e é vendido pela KMV Corporation desde 1989. Seu nome comercial é Credit Monitor Model, porém é mais conhecido como modelo KMV, cuja origem vem dos fundadores Stephen Kealhofer, John Andrew McQuown e Oldrich Alfons ㅌasicek. 
O objetivo central desse modelo é precificar o crédito baseando-se na idéia de que uma empresa pode ser tratada como uma opção.

Para Abe (2002), numa opção de venda, o vendedor cede o direito para que alguém (o comprador) exercite aquela opção numa data futura. Para ceder este direito, recebe na data presente do comprador um prêmio, ou preço da opção que corresponde a remuneração pelo compromisso assumido com o comprador na data futura. Este autor descreve o processo completo do modelo KMV, adequando-o ao mercado brasileiro. $\mathrm{O}$ modelo segue três passos:

I) estimativa do valor e volatilidade do ativo;

II) cálculo da distância à inadimplência; e

III) cálculo da probabilidade de inadimplência.

Neste trabalho, procura-se determinar quando uma empresa específica ficará inadimplente. No caso, a inadimplência é definida como o não pagamento dos juros ou do principal.

Para Aragão et al. (2002), o modelo KMV baseia-se na hipótese de que o mercado é a fonte mais eficiente de informações acerca da saúde financeira de uma empresa. A função de pagamento de um empréstimo está diretamente relacionada com o valor de mercado da empresa devedora. Dessa forma, o modelo KMV, segundo estes autores, considera o incentivo de pagamento por parte dos detentores de capital da empresa devedora. Com isto, torna-se possível determinar uma medida de freqüência esperada de inadimplência.

A aplicação deste modelo para uma carteira de empréstimos com uma grande quantidade de pequenos clientes, como é típico em bancos de varejo, se torna difícil uma vez que não existe a valoração de ações de pequenas empresas ou de pessoas físicas por parte do mercado financeiro. Para uma carteira de financiamentos rurais e agroindustriais ocorre o mesmo tipo de problema onde grande parte das empresas rurais 
não divulgam informações ao mercado, dificultando um acompanhamento de sua "saúde" financeira e conseqüentemente da aplicação deste tipo de modelo.

\subsubsection{O modelo Credit Portfolio View}

Existem evidências empíricas, segundo alguns autores, de que alterações de classificação de bonds ou empréstimos podem, de modo geral, depender do estado da economia. Baseado nestas e em outras evidências, a Mckinsey and Co. em 1997 criou o Credit Portfolio View que considera fatores e efeitos cíclicos da economia.

Saunders (1999) ilustra um exemplo da aplicação da metodologia do Credit Portfolio View para um tomador de classificação C, onde a probabilidade deste tomador inadimplir durante o próximo período (pode ser 1 ano) segue a seguinte equação:

$$
p_{t}=f\left(X_{i t-j} ; V_{t}, \varepsilon_{i t}\right)
$$

onde:

$p_{t}=\quad$ probabilidade de inadimplência do tomador no tempo

$X_{i t-j}=$ conjunto de variáveis macroeconômicas $i$ (sistemáticas) no momento $t$, defasadas de um período $j$

$V_{t}=\quad$ fator de choque econômico geral

$\varepsilon_{i t}=\quad$ fatores de choque para cada uma das variáveis macroeconômicas $i$ no momento $t$

Utilizando-se uma abordagem de simulação Monte Carlo estruturada, podem ser gerados valores para $V_{t}$ e $\varepsilon_{i t}$ para períodos futuros com a mesma probabilidade observada em períodos históricos. Com isso, Saunders (1999) supõe, por exemplo, que o valor simulado para $p_{t}$ seja de 0,35 e que o número da matriz histórica de alteração não condicional seja de 0,3 . Definindo-se a razão $\left(r_{t}\right)$ : 


$$
r_{t}=\frac{p_{t} s}{p_{t} h}=\frac{0,35}{0,3}=1,16
$$

onde:

$p_{t} s=$ probabilidade simulada

$p_{t} h=$ probabilidade histórica

Observa-se que $p_{t} s$ é $16 \%$ maior do que $p_{t} h$, mostrando que o modelo indicaria uma probabilidade de inadimplência para um tomador de classificação " $\mathrm{C}$ " acima de sua média histórica.

Para Aragão et al. (2002), o modelo de fatores da Mckinsey baseia-se na relação entre as probabilidades de inadimplência dos devedores e fatores macroeconômicos, partindo de uma matriz de alteração de classificações semelhante àquela utilizada pelo modelo Credit Metrics. Com isto, é possível estabelecer probabilidades de mudança de classificação mais elevadas em períodos recessivos da economia.

O modelo Credit Portfolio View requer grande quantidade de dados macroeconômicos e de mercado (crédito). Para Duarte (2003), modelos de fatores já se provaram inúteis no caso do mercado acionário e, quando aplicados ao crédito, tornamse extremamente difíceis de se modelar, estimar parâmetros e ponderações para obtenção de resultados coerentes. Para finalizar, o autor destaca que "eventos atípicos" destroem relações macroeconômicas existentes.

\subsubsection{O modelo CreditRisk+}

As idéias utilizadas nas áreas de seguros tiveram sua aplicação estendida recentemente para a área de crédito. Dentro dessa linha, a Credit Suisse Financial Products (CSFP) desenvolveu, ao final de 1996, um modelo semelhante ao que poderia ser utilizado por uma seguradora contra incêndios residenciais ao avaliar o risco de 
perda na determinação de prêmios. Nesse modelo, chamado CreditRisk+, a inadimplência é modelada como variável contínua com uma distribuição de probabilidade.

Uma analogia com o seguro residencial ilustra melhor o conceito utilizado. Quando toda uma carteira de residências é segurada, há uma pequena probabilidade de que cada casa se incendeie, e a probabilidade de que cada casa se incendeie pode ser vista como um evento independente. Assim, cada empréstimo individual é considerado como tendo uma pequena probabilidade de inadimplência, e a probabilidade de inadimplência de cada empréstimo independe da inadimplência de outros empréstimos. Estas considerações fazem com que a distribuição das probabilidades de inadimplência de uma carteira de empréstimos se pareça com a distribuição de Poisson. Especificamente, a distribuição de Poisson implica que o índice médio de inadimplência de uma carteira de empréstimos deve ser igual a sua variância.

Um segundo tipo de incerteza considerado no CreditRisk+, é o tamanho e a severidade das perdas em si. Novamente utiliza-se a analogia do seguro de residências, pois quando uma casa se incendeia o grau de severidade da perda pode variar entre a perda de um telhado e a destruição total da casa.

Para Saunders (1999), o fato dos índices de severidade, no CreditRisk+, serem incertos é reconhecido, mas devido a dificuldade de se medir a severidade em bases individuais empréstimo a empréstimo, as severidades ou exposições de empréstimos são arredondadas e agrupadas em faixas distintas de perda. Para o autor, o foco do CreditRisk+ está na medida de perdas esperadas e não esperadas ao invés de valor esperado e mudanças não esperadas no valor como no Credit Metrics. Outra grande diferença entre esses dois modelos é que no Credit Metrics a probabilidade de inadimplência em qualquer ano é discreta, de acordo com a classificação do empréstimo. A grande vantagem do CreditRisk+ é a pequena quantidade de dados de entrada necessários. Por exemplo, dados sobre os spreads de crédito não são considerados.

O mesmo autor cita como limitações: 
I) a metodologia em si, que supõe que não há risco de mercado; e

II) o fato de se ignorar migrações de risco, ou seja, a exposição de cada tomador é fixa, não depende de mudanças na qualidade de crédito, ou de variações futuras nas taxas de juros.

No modelo CreditRisk + cada devedor tem apenas dois possíveis estados: inadimplente ou não. Para Aragão et. al (2002), seu principal objetivo é a medição de perdas esperadas e inesperadas da carteira. Para medição dos eventos de inadimplência, os empréstimos componentes de uma carteira de crédito são agrupados por faixa de exposição, de modo que a distribuição de inadimplências pode ser aproximada por uma distribuição de Poisson de média $\mu$. Para estes autores, a aproximação só é válida supondo-se que as probabilidades de inadimplência $(p)$ individuais são pequenas e o número de devedores (n) na carteira é alto. A distribuição Binomial seria a forma mais correta $(n)$ devedores com probabilidade de inadimplência $(p)$, entretanto, quando o número de devedores $(n)$ é grande e a probabilidade de inadimplência $(p)$ é baixa, ela converge para a Poisson $(\mu=n . p)$. As probabilidades de inadimplência são modeladas como variáveis aleatórias com distribuição Gamma, sendo que estas probabilidades possuem uma volatilidade que introduz o efeito de correlação do modelo, tornando possível o cálculo do risco diversificado da carteira de crédito. Desta forma, o efeito da distribuição Gamma com a Poisson permite chegar a distribuição de perdas da carteira no modelo CreditRisk+.

Para Crouhy et al. (2000), no modelo CreditRisk+ é suposto que:

I) para um empréstimo, a probabilidade de inadimplência em um dado período, por exemplo, um mês, é a mesma para qualquer outro mês; e,

II) para um grande número de tomadores de empréstimos, a probabilidade de inadimplência para qualquer particular tomador é pequena, e o número de inadimplências que ocorrem em dado período é independente do número de inadimplências que ocorrem em qualquer outro período. 
Conforme Crouhy et al. (2000), as vantagens do CreditRisk+ são:

I) como expressões fechadas são derivadas para a probabilidade de perdas do portfólio de empréstimos, torna-se computacionalmente atrativo; e,

II) devido ao foco na inadimplência, exige poucas entradas para serem estimadas, somente a função de probabilidade de perdas e a exposição ajustada ao risco são necessárias como dados de entrada.

Sua maior limitação é que o CreditRisk+ não é um modelo completo de $V a R$, pois se concentra em taxas de perdas ao invés de mudanças de valores. É um "default model" (DM) ao invés de um modelo "mark-to-market" (MTM) como é o modelo Credit Metrics.

\subsubsection{A estrutura do CreditRisk+}

A estrutura do CreditRisk+ pode ser dividida em dois estágios conforme Figura 7 abaixo:

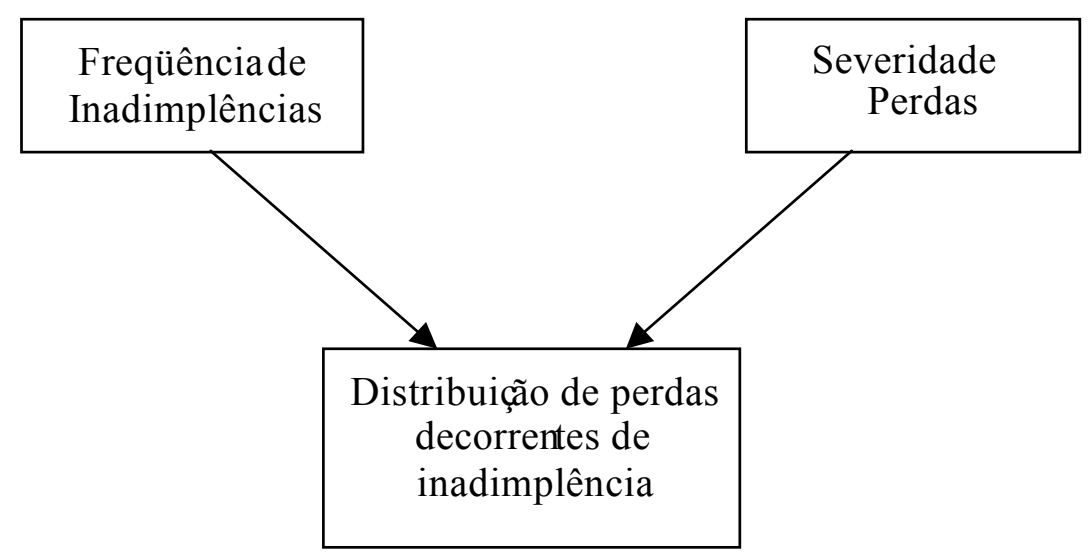

Figura 7 - Estrutura do modelo CreditRisk+.

Fonte: Saunders (1999) 
A frequência de indimplências e a severidade das perdas, ilustradas na Figura 7, mostram os dois tipos de incerteza modelados no CreditRisk+. Essas duas incertezas é que produzem uma distribuição de perdas.

\subsubsection{Função geradora de probabilidade ( FGP )}

Para entender como o CreditRisk + determina a função de distribuição de probabilidade é necessário primeiramente mostrar o tipo de variável auxiliar " $z$ " utilizado em suas equações.

Muitas vezes, em lugar de estudar as expressões analíticas das distribuições de maneira direta, é conveniente trabalhar com a transformação destas expressões, geralmente chamada de "transformada". As "transformadas" são funções de uma variável auxiliar obtidas a partir das distribuições básicas e cuja manipulação torna-se mais simples.

Para as distribuições discretas emprega-se a transformada " $z$ ", também denominada função geradora de probabilidade (FGP), da seguinte maneira:

I) seja $n$ uma variável aleatória discreta $(n \geq 0)$ cuja distribuição de probabilidades é dada por $p(n)$; e

II) a transformada " $z$ " dessa distribuição é definida por

$$
F(z)=\sum_{n=0}^{\infty} p(n) z^{n}
$$

onde:

$z$ é uma variável auxiliar, definida no campo complexo dentro de uma região tal que $F(z)$ exista e seja contínua.

\footnotetext{
${ }^{1}$ ABRAHÃO, J.C.A. Modelos para avaliação e otimização do risco de crédito. São Paulo, 2002. Dissertação (M.S). (em andamento)
} 
As propriedades de uma distribuição de Poisson e de sua transformada, podem ser descritas da seguinte forma:

- Distribuição de Poisson

$$
p(n)=\frac{\lambda^{n} e^{-\lambda}}{n !} \quad \text { para } \mathrm{n} \geq 0 \mathrm{e} \lambda>0
$$

A transformada " $z$ " é dada por:

$$
F(Z)=\sum_{n=0}^{\infty} \frac{\lambda^{n} e^{-\lambda}}{n !} Z^{n}=e^{-\lambda} \sum_{n=0}^{\infty} \frac{(\lambda Z)^{n}}{n !}=e^{-\lambda} e^{\lambda Z}=e^{\lambda(Z-1)}
$$

lembrando que $e^{X}=\sum_{n=0}^{\infty} \frac{(X)^{n}}{n !}$

- Valor esperado:

$$
E[n]=\left.\frac{d\left(e^{\lambda(Z-1)}\right)}{d Z}\right|_{Z=1}=\left.\lambda e^{\lambda(Z-1)}\right|_{Z=1}=\lambda
$$

- Variância:

$$
\operatorname{Var}[n]=\left.\frac{d^{2} F(Z)}{d Z^{2}}\right|_{Z=1}-E^{2}[n]+E[n]=\lambda^{2}-\lambda^{2}+\lambda=\lambda
$$

- Soma de variáveis aleatórias independentes regidas por distribuições de Poisson:

I) sejam $K$ e $m$ duas variáveis aleatórias discretas e independentes regidas por distribuições de Poisson:

$$
\begin{aligned}
& G k=\frac{\lambda_{1}{ }^{n} e^{-\lambda_{1}}}{K !} \quad \text { para } \mathrm{K} \geq 0 \quad \text { e } \\
& \mathrm{Qm}=\frac{\lambda_{2}{ }^{m} e^{-\lambda_{2}}}{m !} \quad \text { para } \mathrm{m} \geq 0
\end{aligned}
$$


II) seja $n$ a variável aleatória obtida pela soma das variáveis $K$ e $m$, então:

$$
F(z)=G(z) \cdot Q(z)=e^{\lambda_{1}(Z-1)} e^{\lambda_{2}(Z-1)}=e^{\left(\lambda_{1}+\lambda_{2}\right)(Z-1)}
$$

Conclui-se, portanto, que a variável $n$ também é regido por uma distribuição de Poisson com média (e variância) igual a $\lambda_{1}+\lambda_{2}$.

A equação 12 ilustra uma transformada "z" padrão.

$$
G(z)=\sum_{n=0}^{\infty} g(n) z^{n}
$$

$\mathrm{Na}$ Tabela 8 são apresentadas as transformadas " $z$ " (FGP) de algumas funções mais comuns em análise de processos estocásticos. 
Tabela 8. Transformadas “ $z$ ” de algumas funções de variáveis discretas.

\begin{tabular}{ll}
\hline Função & \multicolumn{1}{c}{ Transformada “ $z$ ” (FGP) } \\
\hline $\mathrm{g}(\mathrm{n})=\mathrm{p}(\mathrm{n})+\mathrm{q}(\mathrm{n})$ & $G(z)=P(Z)+Q(Z)$ \\
$\mathrm{g}(\mathrm{n})=\mathrm{a} \mathrm{p}(\mathrm{n})($ a constante $)$ & $G(z)=a P(Z)$ \\
$\mathrm{g}(\mathrm{n})=\mathrm{p}(\mathrm{n}-\mathrm{k})(\mathrm{K} \geq 0)$ & $G(z)=Z^{K} P(Z)$ \\
$\mathrm{g}(\mathrm{n})=\mathrm{p}(\mathrm{n}+\mathrm{k})(\mathrm{K} \geq 0)$ & $G(z)=Z^{-K}\left[P(Z)-p(0)-p(1) Z-\ldots-p(K-1) Z^{K-1}\right]$ \\
$\mathrm{g}(\mathrm{n})=\mathrm{n} \mathrm{p}(\mathrm{n})$ & $G(z)=Z \frac{d}{d Z} P(Z)$ \\
$\mathrm{g}(\mathrm{n})=a^{n}$ & $G(z)=\frac{1}{1-a Z}$ \\
$\mathrm{~g}(\mathrm{n})=1$ & $G(z)=\frac{1}{1-Z}$ \\
$\mathrm{~g}(\mathrm{n})=\mathrm{n}$ & $G(z)=\frac{Z}{(1-Z)^{2}}$ \\
$\mathrm{~g}(\mathrm{n})=n^{2}$ & $G(z)=[I-A Z]^{-1} \quad(\mathrm{I}=$ matriz identidade $)$ \\
\hline
\end{tabular}

Fonte: Abrahão, op. cit., p.51 (2002)

Baseado no documento técnico do CSFP (1997), é possível descrever as etapas do modelo CreditRisk+.

\subsubsection{Distribuição dos eventos de inadimplência}

Considerando-se um portfólio de crédito com $N$ empréstimos. Para cada cliente $A$ deste portfólio tem-se uma probabilidade $p_{A}$ deste cliente inadimplir no 
horizonte de análise. A FGP do evento "cliente A vai inadimplir até o final do horizonte de análise" é dada por:

$$
F_{A}(z)=1-p_{A}+p_{A} z=1+p_{A}(z-1)
$$

Se os eventos de inadimplência são independentes, para clientes distintos, a FGP dos eventos de inadimplência do portfólio é:

$$
\begin{aligned}
& F(z)=\prod_{A} F_{A}(z)=\prod_{A}\left(1+p_{A}(z-1)\right) \\
& \ln F(z)=\ln \prod_{A}\left(1+p_{A}(z-1)\right)=\sum_{A} \ln \left(1+p_{A}(z-1)\right)
\end{aligned}
$$

sabe-se que, dada a função $y=\ln (1+\Delta), \Delta \in \mathfrak{R}$, tem-se que:

$$
y^{\prime}=\frac{d(\ln (1+\Delta))}{d \Delta}=\frac{1}{1+\Delta}
$$

logo,

$$
\left.\frac{d y}{d \Delta}\right|_{\Delta=0}=\frac{1}{1+0}=1
$$

através de uma aproximação de Taylor de $1^{\mathrm{a}}$ ordem nas proximidades de $y=0 \mathrm{e}$ $\Delta=$ pequeno:

$$
\left.y(\Delta) \cong \frac{d y}{d \Delta}\right|_{\Delta=0} \Delta
$$

substituindo (17) em (18), tem-se que:

$$
\mathrm{y}(\Delta) \cong 1 \times \Delta=\Delta
$$

$\operatorname{logo}, \ln (1+\Delta) \cong \Delta($ para $\Delta$ pequeno $)$ 
Usando a equação (19) em (15), tem-se que:

$\ln F(z)=\sum_{A} \ln \left(1+p_{A}(z-1)\right) \cong \sum_{A}\left(p_{A}(z-1)\right)=\sum_{A} p_{A}(z-1)=\mu(z-1)$

$\operatorname{com} \mu=\sum_{A} p_{A}$

logo, de (20), $\ln F(z) \cong \mu(z-1)$ então,

$$
F(z)=e^{\mu(z-1)}
$$

Observa-se que (21) é a transformada " $z$ " de uma distribuição de Poisson, ou seja $p(n)=\frac{e^{-\mu} \mu^{n}}{n !}$

A Lei dos eventos raros mostra que quando tem-se vários eventos independentes de sucesso e fracasso, cada qual com uma dada probabilidade de fracasso determinada, então o número de fracassos será aproximadamente distribuído por uma distribuição de Poisson. Essa aproximação será tão melhor quanto menor forem as probabilidades de fracasso de cada evento independente.

Quando se estuda uma carteira de crédito pode-se pensar em um conjunto de eventos independentes de sucesso e fracasso (pagamento ou inadimplência até o final do horizonte de análise, respectivamente). Dessa forma, conclui-se que para cada $A$ no portfólio, a probabilidade de $A$ vir a inadimplir no horizonte de análise é dada por $p_{A}$, então os eventos de inadimplência do portfólio no horizonte de análise são distribuídos de acordo com a distribuição de Poisson. Ou seja, a probabilidade de ocorrerem $n$ eventos de inadimplência no portfólio total até o final do horizonte de análise é dada por:

Probabilidade $\left(\mathrm{n}^{\mathrm{o}}\right.$ de inadimplências $\left.=n\right)=\frac{e^{-\mu} \mu^{n}}{n !}$ 
onde $\mu=\sum_{A} p_{A}$

\subsubsection{Distribuição de perdas com taxas de inadimplências fixas}

Ao analisar o efeito dos eventos de inadimplência no valor da perda em dinheiro, divide-se o portfólio em faixas de exposição. Têm-se as seguintes notações:

$A=$ devedor

$L_{A}=$ exposição do devedor $A$

$P_{A}=$ probabilidade de inadimplência do devedor $A$

$\lambda_{A}=$ perda esperada do devedor $A$

Definindo $L$ como sendo a unidade de quantidade de exposição. Para cada $A$ tem-se:

$$
L_{A}=L v_{A} \text { e } \lambda_{A}=L \varepsilon_{A}
$$

Logo $v_{A}$ e $\varepsilon_{A}$ são respectivamente a exposição e a perda esperada de $A$, dadas como múltiplos inteiros de $L$.

Dividindo-se o portfólio em faixas de exposição, utilizando-se os valores $v_{A}$, cada faixa será definida por um valor comum de $v_{A}$. Obtém-se as faixas $v_{j}, j=1,2, \ldots, m$.

$v_{j}=$ determina a faixa de exposição $j$

$\varepsilon_{j}=$ perda esperada na faixa $j$

$\mu_{j}=$ número esperado de inadimplências na faixa $j$ 
Tem-se as seguintes relações: $\varepsilon_{j}=v_{j} \mu_{j} \Rightarrow \mu_{j}=\frac{\varepsilon_{j}}{v_{j}}=\sum_{A v_{A}=v_{j}} \frac{\varepsilon_{A}}{v_{A}}$

Na relação anterior, $\frac{\varepsilon_{A}}{v_{A}}$ deve-se interpretar como sendo o número esperado de inadimplência de $A$ (que não é necessariamente um número inteiro). Daí a soma dos $\frac{\varepsilon_{A}}{v_{A}}$ é igual a $\mu_{j}$.

Iniciando-se agora o trabalho com o valor das perdas. Já se sabe como os eventos de inadimplência se distribuem ao longo do horizonte de análise. Sabe-se também que eventos de inadimplência distintos podem gerar perdas (em dinheiro) distintas. A vantagem de se trabalhar em faixas de exposição é que uma vez fixado dentro de uma delas, sabe-se exatamente a perda ocorrida. Na faixa de exposição $v_{j}$ um evento de inadimplência gera uma perda de $L v_{j}$. Seguindo-se a descrição do documento técnico, assumi-se a hipótese de que os eventos de inadimplência em duas faixas de exposição distintas são independentes.

Deve-se, então, encontrar a FGP:

$$
\begin{aligned}
& G(z)=\sum_{n=0}^{\infty} p(\text { perda }=n L) z^{n}=\prod_{j=1}^{m} G_{j}(z) \\
& G_{j}(z)=\sum_{n=0}^{\infty} p(\text { inad. }=n) z^{n v_{j}}
\end{aligned}
$$

onde:

$G_{j}(z)$ é a FGP de inadimplências na faixa de exposição $v_{j}$.

Observa-se que na formulação de $G_{j}(z)$ as potências de $z$ são dadas por $n v_{j}$. Isto se deve ao fato de se calcular a distribuição de probabilidade de perda na faixa 
de exposição $v_{j}$. Dessa forma, $n$ eventos de inadimplência geram uma perda igual a $n v_{j} L$. Ao se colocar as potências $z^{n v_{j}}$ na FGP $G_{j}(z)$ está se compatibilizando os eventos de inadimplência com as respectivas perdas associadas. Como é conhecida a função densidade de probabilidade (PDF) dos eventos de inadimplência tem-se:

$$
G_{j}(z)=\sum_{n=0}^{\infty} p(\text { inad. }=n) z^{n v_{j}}=\sum_{n=0}^{\infty} \frac{e^{-\mu_{j}} \mu_{j}^{n}}{n !} z^{n v_{j}}=e^{-\mu_{j}+\mu_{j} z^{v_{j}}}
$$

Logo, chega-se à fórmula da FGP das perdas:

$$
G(z)=\prod_{j=1}^{m} e^{-\mu_{j}+\mu_{j} z^{v_{j}}}=e^{-\sum_{j=1}^{m} \mu_{j}+\sum_{j=1}^{m} \mu_{j} z^{v_{j}}}
$$

Apesar da obtenção da expressão para FGP das perdas, esta não é inteiramente satisfatória. O que necessita-se é escrever uma fórmula passível de ser implementada em computadores dos coeficientes de $G_{j}(z)$. Ou seja, se

$$
G_{j}(z)=\sum_{n=0}^{\infty} A_{n} z^{n}
$$

onde:

$A_{n}=$ probabilidade de se perder $n L$

Tem-se, então, a seguinte fórmula recursiva para os $A_{n}:$ :

$$
\begin{aligned}
& A_{0}=e^{-\mu}=e^{-\sum_{j=1}^{m} \frac{\varepsilon_{j}}{n}} \\
& A_{n}=\sum_{j v_{j \leq n}} \frac{\mu_{j} v_{j}}{n} A_{n-v_{j}}
\end{aligned}
$$


Estas fórmulas recursivas não consideram uma volatilidade do índice médio de inadimplência. Para Saunders (1999), o CreditRisk+ pode ser dividido em dois modelos. O modelo 1 não considera-se incerteza no índice médio de inadimplência e no modelo 2 são consideradas incertezas no índice de inadimplência; incerteza quanto a severidade da perda e a incerteza quanto ao próprio índice médio de inadimplência. Esta última incerteza é modelada como uma distribuição Gamma, isto porque o CreditRisk+ considera que o índice médio de inadimplência pode variar ao longo do tempo.

Este tipo de incerteza pode ser ilustrado no trabalho de Saunders (1999) ao citar Carty e Lieberman (1996) onde estes autores trabalharam com empréstimos de classe "B" e verificaram que o índice médio de inadimplência era de 7,27\%, sua raiz quadrada era de $2,69 \%$ e seu desvio padrão era de 5,1\%, isto é quase duas vezes maior que a raiz quadrada da média.

Para o portfólio real, objeto de estudo deste trabalho, não foram consideradas incertezas quanto ao índice médio de inadimplência. Dessa forma, o modelo utiliza-se das fórmulas recursivas descritas anteriormente.

Saunders (1999) apresenta um exemplo simplificado de cálculo da metodologia do CreditRisk+, conforme ilustrado a seguir. Dividindo-se uma carteira de empréstimos por faixas de valor $\left(v_{i}\right)$, onde a primeira faixa $\left(v_{l}\right)$, isto é, a extremidade mais baixa dos níveis de exposição possui 100 empréstimos, onde cada um tem uma exposição média de $\$ 20.000$. Pode-se pensar nessa faixa contendo todos os empréstimos para os quais as exposições, quando arredondadas para os \$20.000 mais próximos, sejam de $\$ 20.000$. As duas faixas de exposição seguintes representariam todos os empréstimos com exposição de $\$ 40.000\left(v_{2}\right)$ e $\$ 60.000\left(v_{3}\right)$, respectivamente.

No CreditRisk+, cada faixa pode ser vista como uma carteira separada, e a distribuição total de perdas é, portanto, uma agregação das distribuições de perdas individuais. 
Considerando-se que uma média de 3\% $(m=3)$ dos empréstimos da faixa $\left(v_{1}\right)$ se tornam inadimplentes e supondo-se que o índice de inadimplência efetivo siga uma distribuição de Poisson, pode-se calcular a probabilidade de 0 até $N$ inadimplências a partir da utilização da seguinte fórmula:

$$
\text { Prob. }(n \text { inadimplências })=\frac{e^{-m} m^{n}}{n !}
$$

onde:

$m$ = número médio de inadimplências;

$n=$ número de inadimplências considerado, $n=1, \ldots, N$

Assim, a probabilidade de 3 inadimplências é:

Prob. (3 inadimplências) $=\frac{e^{-3} 3^{3}}{3 !}=0,224$ ou $22,4 \%$

Utilizando-se este procedimento é possível obter a Tabela 9 com as probabilidades de inadimplências para a faixa $\left(v_{l}\right)$.

Tabela 9. Exemplo de probabilidade de inadimplência, dado $\mathrm{m}=3$, em \%.

\begin{tabular}{ccc}
\hline Número de Inadimplências & Probabilidade & Probabilidade Acumulada \\
\hline 0 & 4,979 & 4,979 \\
1 & 14,936 & 19,915 \\
2 & 22,404 & 42,319 \\
3 & 22,404 & 64,723 \\
4 & 16,803 & 81,526 \\
5 & 10,082 & 91,608 \\
6 & 5,041 & 96,649 \\
7 & 2,160 & 98,810 \\
8 & 0,810 & 99,620 \\
\hline
\end{tabular}

Fonte: Saunders (1999) 
A Figura 8 mostra a distribuição de inadimplências para a faixa $\left(v_{l}\right)$.

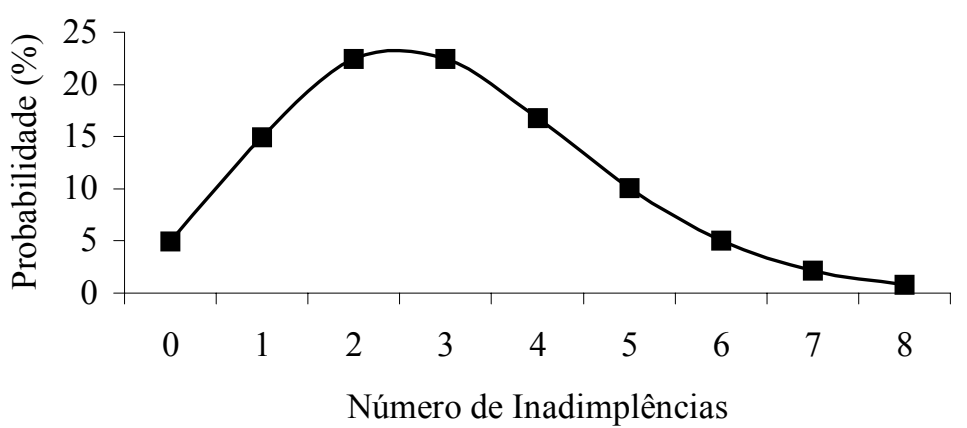

Figura 8 - Distribuição de inadimplências para a faixa $\left(v_{l}\right)$.

Fonte: Saunders (1999)

O cálculo da distribuição de perdas na faixa $\left(v_{l}\right)$ é direto pois, por suposição e arredondamento, a severidade é constante na faixa $\left(v_{l}\right)$ a $\$ 20.000$ por empréstimo. A Figura 9 ilustra a distribuição de perdas onde o número médio de inadimplências é 3.

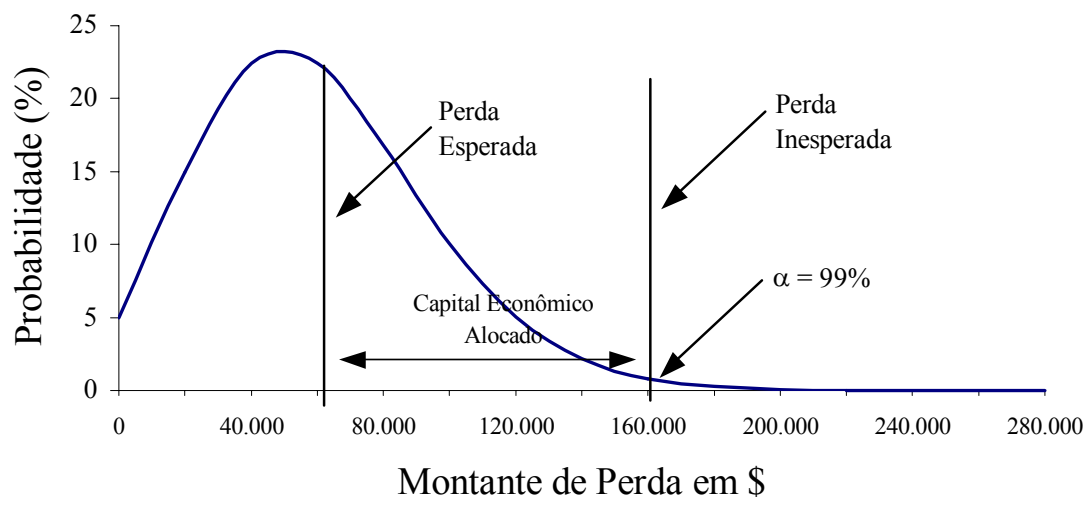

Figura 9 - Distribuição de perdas para faixa $\left(v_{l}\right)$, dado $\mathrm{m}=3$ e $v_{l}=\$ 20.000$.

Fonte: Saunders (1999) 
A perda esperada é, então, de $\$ 60.000$ na faixa $\left(v_{l}\right)$ da carteira de empréstimos. O índice de perdas (inesperadas), do $99^{\circ}$ percentil, mostra um pouco menos de 8 empréstimos em 100 inadimplindo, o que coloca a probabilidade de inadimplência de 8 empréstimos em $0,8 \%$. Utilizando-se 8 empréstimos como aproximação, o índice de perdas inesperadas de 99\% é de $\$ 160.000$ para a carteira $v_{l}$. Considerando-se isoladamente do restante da carteira de empréstimos, o CEA (capital econômico alocado) seria de \$100.000 (\$160.000 - \$60.000).

Utilizando-se o mesmo procedimento para a faixa $\left(v_{2}\right)$ com exposição média de perda de \$40.000, obtém-se a distribuição ilustrada na Figura 10.

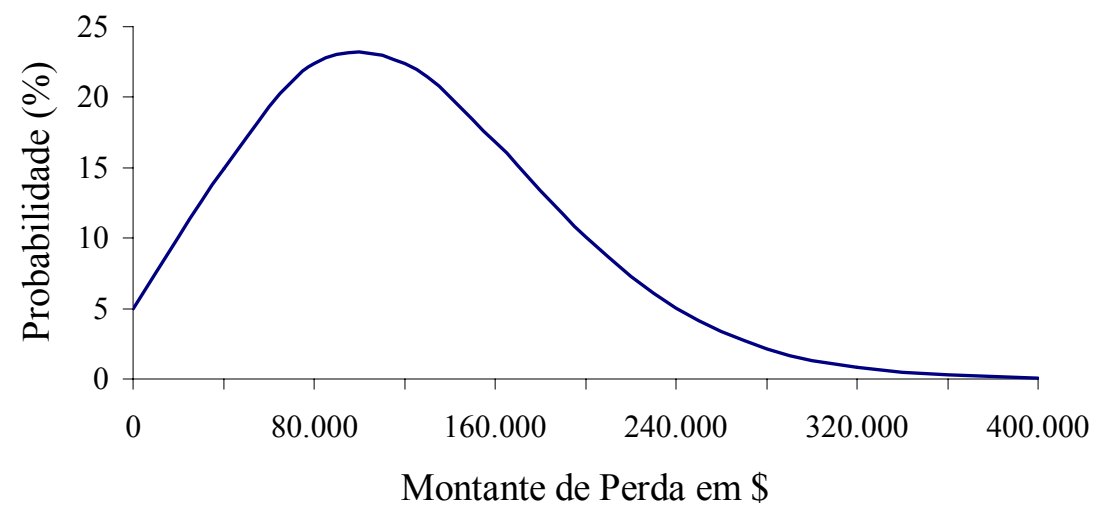

Figura 10 - Distribuição de perdas para a faixa $\left(v_{2}\right)$, dado $\mathrm{m}=3$ e $v_{2}=\$ 40.000$.

Fonte: Saunders (1999)

Se estes fossem os únicos tipos de empréstimos realizados, a agregação de perdas para estas duas faixas seria feita conforme Tabela 10 a seguir. 
Tabela 10. Soma das distribuições de perdas das duas faixas.

\begin{tabular}{ccc}
\hline $\begin{array}{c}\text { Perda Agregada } \\
\text { da Carteira }(\$)\end{array}$ & $\begin{array}{c}\text { Perda por faixa* } \\
\left(v_{l}, v_{2}\right)\end{array}$ & Probabilidade \\
\hline 0 & $(0,0)$ & $(0,0497 \times 0,0497)$ \\
20.000 & $(1,0)$ & $(0,1493 \times 0,0497)$ \\
40.000 & {$[(2,0)(0,1)]$} & {$[(0,224 \times 0,0497)+(0,0497 \times 0,1493)]$} \\
60.000 & {$[(3,0)(1,1)]$} & {$\left[(0,224 \times 0,0497)+(0,1493)^{2}\right]$} \\
80.000 & {$[(4,0)(2,1)(0,2)]$} & {$[(0,168 \times 0,0497)+(0,224 \times 0,1493)+(0,0497 \times 0,224)]$} \\
$\ldots$ & $\ldots$ & $\ldots$ \\
\hline
\end{tabular}

Fonte: Saunders (1999)

(*) Perda em $v_{1}$ e $v_{2}$ em unidades de $\$ 20.000$ e $\$ 40.000$, respectivamente.

Finalizando, ilustra-se um comparativo entre os principais modelos descritos neste capítulo conforme mostra a Tabela 11.

Tabela 11. Comparativo entre os principais modelos.

\begin{tabular}{|c|c|c|c|c|}
\hline $\begin{array}{l}\text { Dimensões de } \\
\text { Comparação }\end{array}$ & Credit Metrics & $\begin{array}{c}\text { Credit Portfolio } \\
\text { View }\end{array}$ & CreditRisk+ & KMV \\
\hline Definição de risco & MTM & MTM ou DM & DM & MTM ou DM \\
\hline $\begin{array}{l}\text { Impulsionadores de } \\
\text { risco }\end{array}$ & Valores de ativos & Fatores macro & $\begin{array}{l}\text { Índices de inadimplência } \\
\text { esperada }\end{array}$ & $\begin{array}{l}\text { Valores de } \\
\text { ativos }\end{array}$ \\
\hline $\begin{array}{l}\text { Volatilidade de } \\
\text { eventos de crédito }\end{array}$ & Constante & Variável & Variável & Variável \\
\hline $\begin{array}{l}\text { Correlação de } \\
\text { eventos de crédito }\end{array}$ & $\begin{array}{l}\text { Retornos sobre } \\
\text { ativos normais } \\
\text { multivariáveis }\end{array}$ & $\begin{array}{l}\text { Carregamentos } \\
\text { de fatores }\end{array}$ & $\begin{array}{l}\text { Suposição de } \\
\text { independência ou } \\
\text { correlação com índice de } \\
\text { inadimplência esperada }\end{array}$ & $\begin{array}{l}\text { Retornos sobre } \\
\text { ativos normais } \\
\text { multivariáveis }\end{array}$ \\
\hline $\begin{array}{l}\text { Índices de } \\
\text { recuperação }\end{array}$ & Aleatórios & Aleatórios & $\begin{array}{l}\text { Constantes dentro da } \\
\text { faixa }\end{array}$ & $\begin{array}{l}\text { Constantes ou } \\
\text { aleatórios }\end{array}$ \\
\hline Abordagem numérica & $\begin{array}{l}\text { Simulação ou } \\
\text { analítica }\end{array}$ & Simulação & Analítica & Analítica \\
\hline
\end{tabular}

Fonte: Saunders (1999) 
Pela Tabela 11 observa-se que o modelo CreditRisk+ possui como impulsionador de risco o índice médio de inadimplência, que pode ser considerado como sendo relacionado ao "estado da macroeconomia", isto é, quando a macroeconomia se deteriora, o índice médio de inadimplência geralmente se eleva, assim como as perdas decorrentes de inadimplência. Quanto a volatilidade de eventos de crédito, considera-se que, no CreditRisk+, a probabilidade de cada empréstimo inadimplir é variável em conformidade com uma distribuição de Poisson em torno de algum índice médio de inadimplência Esse índice médio de inadimplência pode ser considerado fixo ou variável com uma distribuição Gamma. Isso tende a produzir uma distribuição de perdas com variâncias maiores do que as obtidas pelos modelos Credit Metrics e Credit Portfolio View. Além disso, o CreditRisk+ considera que os eventos de crédito são independentes, não necessitando da determinação da correlação prévia como dado de entrada. Por fim, sua abordagem analítica possui maior facilidade de aplicação e obtenção de dados para o cálculo do valor em risco e conseqüentemente do capital econômico alocado.

Em função dessas características o CreditRisk+ tem sido adaptado e utilizado por alguns bancos de varejo presentes no cenário brasileiro. Sendo assim, optou-se pela sua utilização na análise do portfólio de financiamentos rurais e agroindustriais em estudo. Maiores detalhes do CreditRisk+ podem ser encontrados no documento técnico disponibilizado pelo CSFP (1997). 


\title{
3 MATERIAL E MÉTODOS
}

\author{
Para quantificar o risco envolvido nos financiamentos rurais e \\ agroindustriais é necessário um conhecimento detalhado das características de cada \\ empréstimo. Assim, o tipo de abordagem metodológica empregado determina o grau de \\ detalhamento que o portfólio deve fornecer. Este capítulo ilustra os dados de \\ financiamentos rurais e agroindustriais utilizados no processo de quantificação de risco, \\ mostrando as classificações de cada tomador, o valor de empréstimo concedido, setor de \\ atividade a que estão vinculados e tipo de modalidade do crédito.
}

Após a apresentação dos dados, descreve-se a obtenção do $V a R$ do portfólio de crédito rural e consequentemente do CEA a partir do modelo CreditRisk+. Em seguida, ilustra-se o procedimento para obter a contribuição de risco de cada tomador. Essa sequência de procedimentos é realizada para dois cenários distintos, sendo que o primeiro baseia-se no percentual de provisionamento do BACEN para determinar a probabilidade de eventos de inadimplência e o segundo baseia-se em uma matriz de migração de classificação que determina o percentual de eventos de inadimplência, obtida especificamente para os setores rurais e agroindustriais abordados neste trabalho, para o período de 2000 a 2002.

\subsection{Base de dados}

A base de dados selecionada para aplicação da metodologia de quantificação de risco de crédito refere-se a uma carteira de financiamento rurais e agroindustriais para pessoa jurídica. Esta carteira, referente ao mês de março de 2003, é composta por 113 clientes distribuídos em 22 setores de atividades localizados em todo o território 
brasileiro. Este portfólio apresenta seis modalidades de empréstimos conforme ilustra a Figura 11.

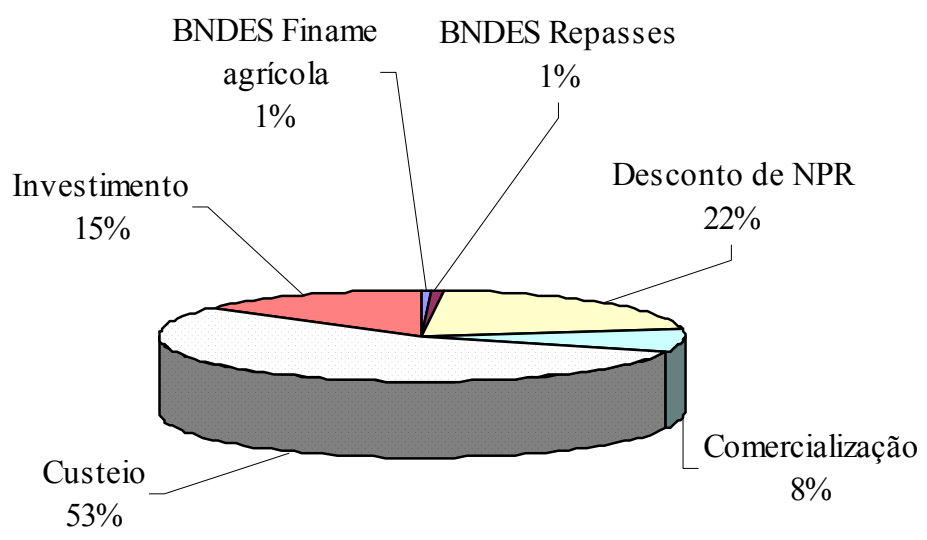

Figura 11 - Distribuição do portfólio de crédito rural por modalidade, março de 2003. Fonte: dados da pesquisa.

Os repasses do BNDES, ilustrados na Figura 11, referem-se as linhas destinadas a aquisição de máquinas e equipamentos, em que a instituição financeira credenciada analisa e aprova a operação, assumindo o risco do crédito. A taxa de comissão de repasses (spread do agente) e as garantias também são negociadas e definidas junto à instituição. A maior representatividade é da modalidade de custeio, com 53\% do total, referente a liberação de recursos para que o produtor ou a agroindústria possa inicializar sua produção. Os descontos de Nota Promissória Rural (NPR) são basicamente destinados a comercialização da safra, representando $22 \%$ do total do portfólio. Os recursos destinados ao investimento em infraestrutura e benfeitorias representam $15 \%$ do total de empréstimos. Já a comercialização, com $8 \%$ do total, refere-se as linhas destinadas para a venda de produtos agrícolas, principalmente para produtos de exportação. 
O portfólio real totaliza $\mathrm{R} \$ 1,42$ bilhões referentes ao mês de março de 2003. Isso representa mais de $10 \%$ do total de financiamentos rurais e agroindustriais que se encontrava alocado no sistema financeiro privado em março de 2003. Esse portfólio caracteriza-se pela sua grande concentração de risco de crédito em apenas 113 clientes. Define-se risco de crédito como sendo o montante de empréstimo concedido. Um melhor detalhamento deste portfólio, bem como a classificação dos clientes e os setores de atividade a que esses estão vinculados são ilustrados na Tabela 12.

Tabela 12. Dados de entrada por setor de atividade e classificação.

\begin{tabular}{llcr}
\hline Cliente & \multicolumn{1}{c}{ Setor de Atividade } & Classificação & \multicolumn{1}{c}{$\begin{array}{c}\text { Risco de } \\
\text { Crédito (R\$) }\end{array}$} \\
\hline Empresa 1 & Fumo & AA & 11.750 .181 \\
Empresa 2 & Produção agrícola & AA & 9.124 .546 \\
Empresa 3 & Produção de sementes e mudas & AA & 10.015 .750 \\
Empresa 4 & Ind. de laticínios & AA & 2.962 .311 \\
Empresa 5 & Ind. de cigarros & AA & 174.321 .893 \\
Empresa 6 & Ind. de suco de laranja & AA & 3.353 .830 \\
Empresa 7 & Ind. de laticínios & AA & 185.081 .502 \\
Empresa 8 & Ind. de adubos e fertilizantes químicos & AA & 22.698 .322 \\
Empresa 9 & Ind. de suco de laranja & AA & 11.192 .114 \\
Empresa 10 & Ind. de inseticidas e defensivos & AA & 76.634 .019 \\
Empresa 11 & Produção de sementes e mudas & AA & 16.902 .700 \\
Empresa 12 & Industrialização da soja e derivados & AA & 58.225 .324 \\
Empresa 13 & Ind. de inseticidas e defensivos & AA & 24.809 .342 \\
Empresa 14 & Ind. de resinas de fibras e fios sintéticos & AA & 62.941 .728 \\
Empresa 15 & Ind. de máquinas e equipamentos agrícolas & AA & 11.950 .545 \\
Empresa 16 & Produção agrícola & A & 18.695 .607 \\
Empresa 17 & Beneficiamento, moagem e torrefação de café & A & 6.431 .614 \\
Empresa 18 & Industrialização de carnes & A & 29.624 .972 \\
Empresa 19 & Beneficiamento de arroz & A & 11.538 .815
\end{tabular}


Tabela 12. Dados de entrada por setor de atividade e classificação.

\begin{tabular}{|c|c|c|c|}
\hline Cliente & Setor de Atividade & Classificação & $\begin{array}{c}\text { Risco de } \\
\text { Crédito }(\mathrm{R} \$)\end{array}$ \\
\hline Empresa 20 & Ind. de laticínios & A & 692.698 \\
\hline Empresa 21 & Industrialização de carnes & A & 87.008 .152 \\
\hline Empresa 22 & Usinas de açúcar e álcool & A & 3.452 .216 \\
\hline Empresa 23 & Produção de cana-de-açúcar & A & 483.089 \\
\hline Empresa 24 & Produção de cana-de-açúcar & A & 399.804 \\
\hline Empresa 25 & Usinas de açúcar e álcool & A & 1.315 .612 \\
\hline Empresa 26 & Usinas de açúcar e álcool & A & 3.922 .725 \\
\hline Empresa 27 & Usinas de açúcar e álcool & A & 2.445 .270 \\
\hline Empresa 28 & Ind. de suco de laranja & A & 26.729 .463 \\
\hline Empresa 29 & Usinas de açúcar e álcool & A & 1.045 .377 \\
\hline Empresa 30 & Usinas de açúcar e álcool & A & 9.408 .786 \\
\hline Empresa 31 & Ind. de adubos e fertilizantes químicos & A & 8.188 .289 \\
\hline Empresa 32 & Usinas de açúcar e álcool & A & 2.950 .093 \\
\hline Empresa 33 & Ind. de inseticidas e defensivos & A & 5.168 .898 \\
\hline Empresa 34 & Ind. de adubos e fertilizantes químicos & A & 407.453 \\
\hline Empresa 35 & Fumo & A & 95.872 .959 \\
\hline Empresa 36 & Industrialização da soja e derivados & A & 5.883 .100 \\
\hline Empresa 37 & Industrialização de carnes & A & 51.626 .117 \\
\hline Empresa 38 & Produção de sementes e mudas & A & 11.230 .543 \\
\hline Empresa 39 & Produção agrícola & A & 17.961 .907 \\
\hline Empresa 40 & Ind. de adubos e fertilizantes químicos & A & 25.279 .588 \\
\hline Empresa 41 & Avicultura & A & 20.232 .187 \\
\hline Empresa 42 & Avicultura & A & 53.519 \\
\hline Empresa 43 & Ind. de laticínios & $\mathrm{A}$ & 5.329 .618 \\
\hline Empresa 44 & Ind. de máquinas e equipamentos agrícolas & B & 19.525 .353 \\
\hline Empresa 45 & Avicultura & $\mathrm{B}$ & 1.001 .866 \\
\hline Empresa 46 & Ind. de inseticidas e defensivos & $\mathrm{B}$ & 312.605 \\
\hline Empresa 47 & Ind. de laticínios & $\mathrm{B}$ & 481.907 \\
\hline Empresa 48 & Avicultura & $\mathrm{B}$ & 1.012 .426 \\
\hline
\end{tabular}


Tabela 12. Dados de entrada por setor de atividade e classificação.

\begin{tabular}{|c|c|c|c|}
\hline Cliente & Setor de Atividade & Classificação & $\begin{array}{c}\text { Risco de } \\
\text { Crédito (R\$) } \\
\end{array}$ \\
\hline Empresa 49 & Avicultura & $\mathrm{B}$ & 44.812 \\
\hline Empresa 50 & Ind. de sucos naturais & $\mathrm{B}$ & 6.687 .384 \\
\hline Empresa 51 & Ind. de resinas de fibras e fios sintéticos & $\mathrm{B}$ & 8.158 .347 \\
\hline Empresa 52 & Usinas de açúcar e álcool & $\mathrm{B}$ & 51.488 \\
\hline Empresa 53 & Usinas de açúcar e álcool & $\mathrm{B}$ & 4.155 .331 \\
\hline Empresa 54 & Usinas de açúcar e álcool & $\mathrm{B}$ & 6.356 .743 \\
\hline Empresa 55 & Produção de café & $\mathrm{B}$ & 60.788 \\
\hline Empresa 56 & Ind. de laticínios & $\mathrm{B}$ & 119.347 \\
\hline Empresa 57 & Ind. de laticínios & $\mathrm{B}$ & 142.891 \\
\hline Empresa 58 & Fumo & $\mathrm{B}$ & 76.891 .500 \\
\hline Empresa 59 & Cooperativa de crédito & $\mathrm{B}$ & 2.041 .432 \\
\hline Empresa 60 & Produção de cana-de-açúcar & $\mathrm{B}$ & 5.100 .534 \\
\hline Empresa 61 & Usinas de açúcar e álcool & $\mathrm{B}$ & 1.480 .209 \\
\hline Empresa 62 & Beneficiamento de arroz & $\mathrm{B}$ & 80.187 \\
\hline Empresa 63 & Beneficiamento de arroz & $\mathrm{B}$ & 1.012 .898 \\
\hline Empresa 64 & Usinas de açúcar e álcool & $\mathrm{B}$ & 3.448 .430 \\
\hline Empresa 65 & Produção de cana-de-açúcar & B & 54.638 \\
\hline Empresa 66 & Produção de café & B & 5.091 .152 \\
\hline Empresa 67 & Produção de cana-de-açúcar & $\mathrm{B}$ & 31.771 \\
\hline Empresa 68 & Industrialização da soja e derivados & $\mathrm{B}$ & 6.518 .200 \\
\hline Empresa 69 & Ind. de laticínios & B & 589.397 \\
\hline Empresa 70 & Beneficiamento de arroz & $\mathrm{B}$ & 2.019 .668 \\
\hline Empresa 71 & Beneficiamento de arroz & $\mathrm{B}$ & 1.012 .886 \\
\hline Empresa 72 & Beneficiamento de arroz & $\mathrm{B}$ & 400.653 \\
\hline Empresa 73 & Beneficiamento, moagem e torrefação de café & $\mathrm{B}$ & 1.480 .224 \\
\hline Empresa 74 & Produção de cana-de-açúcar & B & 1.127 .244 \\
\hline Empresa 75 & Ind. de laticínios & $\mathrm{B}$ & 496.248 \\
\hline Empresa 76 & Ind. de adubos e fertilizantes químicos & $\mathrm{B}$ & 209.212 \\
\hline Empresa 77 & Ind. de laticínios & $\mathrm{B}$ & 241.929 \\
\hline
\end{tabular}


Tabela 12. Dados de entrada por setor de atividade e classificação.

\begin{tabular}{|c|c|c|c|}
\hline Cliente & Setor de Atividade & Classificação & $\begin{array}{c}\text { Risco de } \\
\text { Crédito (R\$) } \\
\end{array}$ \\
\hline Empresa 78 & Beneficiamento, moagem e torrefação de café & $\mathrm{B}$ & 711.775 \\
\hline Empresa 79 & Moagem de trigo & $\mathrm{B}$ & 519.718 \\
\hline Empresa 80 & Abate de aves & $\mathrm{B}$ & 316.752 \\
\hline Empresa 81 & Moagem de trigo & $\mathrm{B}$ & 831.743 \\
\hline Empresa 82 & Moagem de trigo & $\mathrm{B}$ & 305.787 \\
\hline Empresa 83 & Moagem de trigo & $\mathrm{B}$ & 206.199 \\
\hline Empresa 84 & Avicultura & $\mathrm{B}$ & 825.005 \\
\hline Empresa 85 & Beneficiamento de arroz & $\mathrm{B}$ & 504.917 \\
\hline Empresa 86 & Beneficiamento de arroz & $\mathrm{B}$ & 803.038 \\
\hline Empresa 87 & Fumo & $\mathrm{B}$ & 10.140 .920 \\
\hline Empresa 88 & Moagem de trigo & $\mathrm{B}$ & 472.919 \\
\hline Empresa 89 & Ind. de adubos e fertilizantes químicos & $\mathrm{B}$ & 9.635 .370 \\
\hline Empresa 90 & Abate de aves & $\mathrm{B}$ & 8.978 .097 \\
\hline Empresa 91 & Fumo & $\mathrm{B}$ & 5.011 .748 \\
\hline Empresa 92 & Moagem de trigo & $\mathrm{B}$ & 519.113 \\
\hline Empresa 93 & Ind. de laticínios & $\mathrm{C}$ & 34.962 \\
\hline Empresa 94 & Ind. de laticínios & $\mathrm{C}$ & 182.956 \\
\hline Empresa 95 & Industrialização de carnes & $\mathrm{C}$ & 40.259 \\
\hline Empresa 96 & Ind. de laticínios & $\mathrm{C}$ & 1.168 .094 \\
\hline Empresa 97 & Abate de aves & $\mathrm{C}$ & 286.734 \\
\hline Empresa 98 & Ind. de inseticidas e defensivos & $\mathrm{C}$ & 32.652 .647 \\
\hline Empresa 99 & Ind. de adubos e fertilizantes químicos & $\mathrm{C}$ & 848.291 \\
\hline Empresa 100 & Ind. de adubos e fertilizantes químicos & $\mathrm{C}$ & 5.380 .024 \\
\hline Empresa 101 & Usinas de açúcar e álcool & $\mathrm{C}$ & 493.059 \\
\hline Empresa 102 & Ind. de inseticidas e defensivos & $\mathrm{C}$ & 221.258 \\
\hline Empresa 103 & Beneficiamento de arroz & $\mathrm{C}$ & 1.215 .477 \\
\hline Empresa 104 & Cooperativa de crédito & $\mathrm{C}$ & 10.409 .146 \\
\hline Empresa 105 & Beneficiamento, moagem e torrefação de café & $\mathrm{C}$ & 147.116 \\
\hline Empresa 106 & Ind. de inseticidas e defensivos & $\mathrm{C}$ & 4.986 .035 \\
\hline
\end{tabular}


Tabela 12. Dados de entrada por setor de atividade e classificação.

\begin{tabular}{llcr}
\hline Cliente & \multicolumn{1}{c}{ Setor de Atividade } & Classificação & \multicolumn{1}{c}{$\begin{array}{c}\text { Risco de } \\
\text { Crédito (R\$) }\end{array}$} \\
\hline Empresa 107 & Usinas de açúcar e álcool & $\mathrm{C}$ & 890.613 \\
Empresa 108 & Beneficiamento, moagem e torrefação de café & $\mathrm{C}$ & 1.182 .364 \\
Empresa 109 & Produção de sementes e mudas & $\mathrm{C}$ & 3.499 .471 \\
Empresa 110 & Moagem de trigo & $\mathrm{C}$ & 3.421 .521 \\
Empresa 111 & Fumo & $\mathrm{C}$ & 3.274 .613 \\
Empresa 112 & Moagem de trigo & $\mathrm{C}$ & 1.024 .290 \\
Empresa 113 & Cooperativa de crédito & $\mathrm{B}$ & 11.224 .924 \\
Total & & & 1.415 .149 .233
\end{tabular}

Fonte: dados da pesquisa.

A Figura 12 ilustra a distribuição do risco de crédito por setor de atividade.

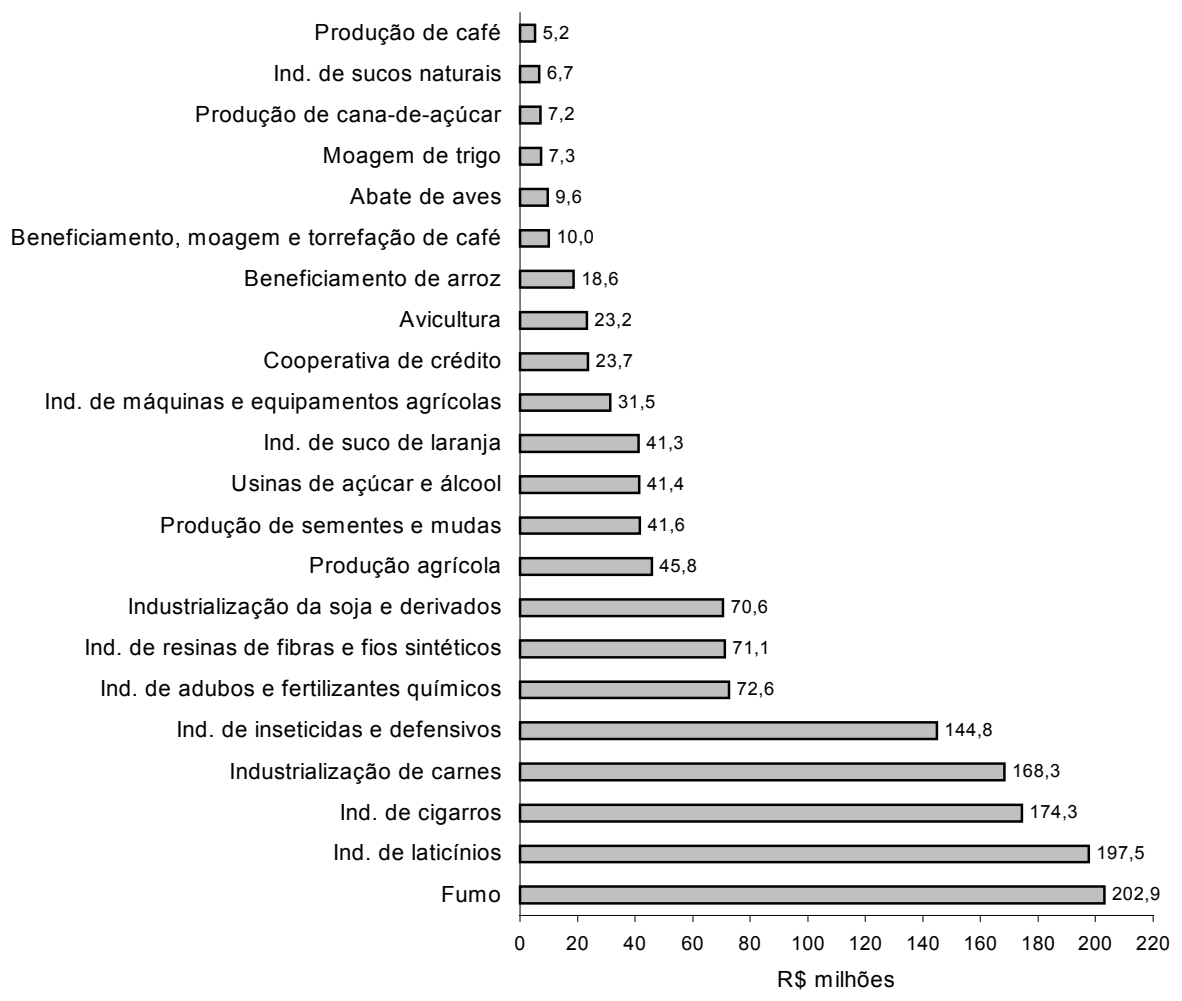

Figura 12 - Distribuição do risco de crédito por setor de atividade.

Fonte: dados da pesquisa. 
A classificação de cada cliente foi atribuída através de um modelo proprietário que segue como base as informações descritas anteriormente no item 2.4. A partir destas classificações, cada cliente passa a ter um provisionamento necessário em função do crédito concedido. A Resolução BACEN 2682 (Anexo B) determina o percentual de provisionamento que deve ser feito para a carteira de operações de crédito, de acordo com a classificação de cada cliente, objetivando neutralizar as perdas prováveis esperadas. Relacionando-se a Tabela 1 com a Tabela 2, obtem-se a Tabela 13 que ilustra o percentual de provisionamento determinado pelo BACEN de acordo com a classificação da operação.

Tabela 13. Provisionamento e classificação por dias de atraso.

\begin{tabular}{lccccccccc}
\hline Item & AA & A & B & C & D & E & F & G & H \\
\hline Provisão (\%) & 0 & 0,5 & 1 & 3 & 10 & 30 & 50 & 70 & 100 \\
Atraso (dias) & - & - & $15-30$ & $31-60$ & $61-90$ & $91-120$ & $121-150$ & $151-180$ & $>180$
\end{tabular}

Fonte: Banco Central do Brasil (1999)

O portfólio apresentado anteriormente na tabela 12 não possui operações com atraso, porém o modelo proprietário da instituição, fornecedora dos dados, atribui classificações piores que "AA" e "A" para seus clientes, conforme ilustra a Tabela 14.

Tabela 14. Distribuição do risco de crédito do portfólio por classificação, em R\$.

\begin{tabular}{lccccc}
\hline Item & AA & A & B & C & Total \\
\hline Empréstimos & 681.964 .105 & 453.378 .472 & 208.447 .726 & 71.358 .931 & 1.415 .149 .235
\end{tabular}

Fonte: dados da pesquisa. 
Baseado nestes dados de entrada, a quantificação do risco de crédito do portfólio real utiliza-se do conceito de RAROC definido anteriormente, o qual mede o retorno em relação ao capital ajustado no risco.

O cálculo do RAROC tem como principal desafio a determinação do $C E A$. Dessa forma, o processo de quantificação deste capital econômico utiliza-se da metodologia exposta para o modelo CreditRisk+ (descrito no item 2.8.4).

A Resolução BACEN 2099, complementada pela Resolução BACEN 2399 (Anexo C), determina o requerimento de alocação mínima de capital voltado para perdas não esperadas e portanto, que não estariam sujeitas a um provisionamento. Seria um montante adicional de requerimento de capital.

As determinações das resoluções do BACEN podem ser associadas ao modelo utilizado, conforme ilustrado na tabela 15.

Tabela 15. Premissas do modelo versus Resoluções do BACEN.

\begin{tabular}{lc}
\hline Premissas do modelo & Resolução \\
\hline Perda Esperada & Resolução BACEN 2682 \\
$C E A=V a R-$ Perda Esperada & Resolução BACEN 2099 e 2399 \\
\hline
\end{tabular}

Fonte: dados da pesquisa.

\subsection{Metodologia}

A quantificação do risco de crédito do portfólio real em estudo utiliza-se dos seguintes conceitos gerais:

I) distribuição de perdas, isto é, um conjunto de pontos formado pelas perdas e suas respectivas probabilidades de ocorrência; 
II) perda esperada, isto é, a média de perdas de um portfólio, num dado horizonte de tempo;

III) perda não esperada, isto é, o montante de perda apurada que excede a perda esperada;

IV) $V a R$, isto é, a maior perda que pode ocorrer com um determinado nível de certeza pré-determinado;

V) $C E A$, isto é, o montante de capital que cobre a diferença entre o $V a R$ e a perda esperada; $\mathrm{e}$

VI) RAROC, isto é, retorno ajustado ao risco medindo o desempenho de um portfólio.

Sendo assim, utiliza-se a seguinte notação para definição do método a ser utilizado:

I) $\operatorname{VaR} 99,99 \%=\mathrm{VaR}$ com $99,99 \%$ de confiança (nível de confiança adotado);

II) $\quad P E=$ perda esperada da carteira;

III) $\sigma=$ desvio padrão da carteira;

IV) $R C_{i}=$ contribuição de risco do tomador $i$ calculada para o $V a R$ de 99,99\% de confiança;

V) $\quad P C_{i}=$ peso na contribuição de risco do tomador $i$;

VI) $\quad E_{i}=$ exposição de empréstimo de cada tomador $i$;

VII) $P D D_{i}=$ provisão para devedores duvidosos de cada tomador $i$;

VIII) $P d_{i}=$ probabilidade de inadimplência do tomador $i$; e 
IX) $\quad m=$ quantidade total de tomadores de empréstimo, onde $i$ varia de 1 até $m$.

As equações (27) e (28), descritas no capítulo anterior, permitem calcular o VaR do portfólio, mas é necessário determinar qual a participação de cada tomador de empréstimo no CEA total do portfólio. Dessa forma, seguindo a metodologia descrita pelo CreditRisk+, tem-se a seguinte equação para o peso de cada tomador na contribuição de risco:

$$
P C_{i}=\left(\frac{E_{i}^{2} P d_{i}}{\sigma}\right)
$$

Para o cenário 1 , o valor de $P d_{i}$ será considerado como sendo o mesmo percentual de provisionamento proposto pelo BACEN a partir da Resolução 2682. Esta aproximação faz com que o percentual de provisionamento para a classificação de um determinado tomador $i$ seja considerado como número de eventos de inadimplência ocorrido para a classificação. Dessa forma, tem-se, por exemplo:

- "Empresa 21" (Tabela 12) com risco de R\$87.008.152 e classificação "A", tem-se:

$$
P d_{21}=\frac{R \$ 87.008 .152 \times 0,5 \%}{R \$ 87.0081 .52} \text { então, } P d_{21}=0,5 \%
$$

Para a perda esperada $(P E)$ tem-se:

$$
P E=\sum_{i=1}^{m} E_{i} P d_{i}
$$

onde:

$m$ é o total de tomadores.

O desvio padrão $(\sigma)$ da carteira é dado por: 
$\sigma=\sqrt{\sum_{i=1}^{n} E_{i}^{2} P d_{i}}$

A contribuição de risco do modelo de cada tomador é dada por:

$R C_{i}=P C_{i}\left(\frac{V a R 99,99 \%-P E}{\sigma}\right)$

Capital econômico alocado $(C E A)$ do portfólio é dado por:

$C E A=\sum_{i=1}^{m} R C_{i}$

A partir do valor encontrado pela equação (33), utiliza-se as equações (1) e (2) sem considerar os termos TA (Taxas Adicionais) e OCO (Outros Custos Operacionais), obtêm-se:

$$
\text { RAROC }=\frac{L E}{C E A}
$$

e,

$$
L E=S-P E
$$

onde:

$L E=$ lucro econômico que mede a lucratividade da operação;

$S=$ spread; e,

$P E=$ perdas esperadas

Observa-se que na equação do RAROC não foram considerados valores de recuperação de crédito. 
Uma vez calculado o $C E A$ do portfólio real, é possível mostrar a variação no spread do portfólio à medida que varia-se o RAROC. Isto está ilustrado no próximo capítulo de resultados.

Para o cenário 2, construiu-se uma matriz de migração dos clientes pertencentes aos 22 setores de atividade, considerados no portfólio original, ao longo de dois anos. Esta matriz de migração levou em consideração a classificação de todos os clientes em comum entre os meses de dezembro de 2000 e dezembro de 2001. Em seguida considerou-se a classificação dos clientes em comum entre os meses de dezembro de 2001 e dezembro de 2002. A matriz obtida para migração de clientes ao longo de um ano foi feita a partir de 713 clientes em comum. Isso resultou na Tabela 16.

Tabela 16. Matriz de migração de clientes após um ano, em \%.

\begin{tabular}{ccccccc}
\hline De/Para & AA & A & B & C & E & F \\
\hline AA & 97,7 & 2,3 & & & & \\
A & & 68,4 & 22,8 & 7,4 & 1,5 & \\
B & & 13,4 & 71,5 & 10,5 & 3,0 & 1,6 \\
C & & 1,4 & 25,9 & 63,9 & 4,8 & 4,1 \\
\hline
\end{tabular}

Fonte: dados da pesquisa.

Considerando-se que os clientes que migraram, após um ano, para classificação "E" e "F" possuíam um atraso maior que 90 dias nas operações, conforme Resolução BACEN 2682, o cenário 2 utilizou-se a soma do percentual migrado para estas duas classificações como sendo o percentual de inadimplências da classificação original. A Tabela 17 compara os valores obtidos para $P d_{i}$ em função de eventos de inadimplência com os valores de provisionamento determinados pelo BACEN. 
Tabela 17. Provisionamento BACEN versus matriz de migração de clientes, em \%.

\begin{tabular}{lcccc}
\hline Item & AA & A & B & C \\
\hline Provisionamento BACEN (cenário 1) & - & 0,5 & 1,0 & 3,0 \\
Matriz de migração de clientes (cenário 2) & - & 1,5 & 4,6 & 8,8 \\
\hline
\end{tabular}

Fonte: dados da pesquisa.

Os novos valores de eventos de inadimplência determinam um novo $C E A$ para o portfólio e conseqüentemente, um novo spread para o mesmo RAROC desejado. Isto é ilustrado no capítulo seguinte. 


\section{RESULTADOS}

A partir da metodologia descrita no capítulo anterior para o cálculo do $V a R$, considerou-se intervalos de $\mathrm{R} \$ 50.000,00$ para alimentar o modelo CreditRisk+. A Tabela 18 ilustra as probabilidades acumuladas para cada cenário a ser considerado nesta pesquisa.

Tabela 18. Probabilidade acumulada por faixa de valor de perda, em \%.

\begin{tabular}{ccc}
\hline Valor de Perda $(\mathrm{R} \$)$ & Cenário 1 & Cenário 2 \\
\hline 0 & 28,938 & 1,138 \\
$50.000,00$ & 31,253 & 1,444 \\
$100.000,00$ & 32,648 & 1,711 \\
$150.000,00$ & 34,202 & 1,981 \\
$\ldots$ & $\ldots$ & $\ldots$ \\
$172.700 .000,00$ & 99,989 & 99,803 \\
$172.750 .000,00$ & 99,989 & 99,803 \\
$172.800 .000,00$ & 99,990 & 99,804 \\
$\ldots$ & - & $\ldots$ \\
$236.900 .000,00$ & - & 99,989 \\
$236.950 .000,00$ & - & 99,990 \\
\hline
\end{tabular}

Fonte: dados da pesquisa. 
Com 99,99\% de confiabilidade, observa-se que o $V a R$, é de $\mathrm{R} \$ 172,8$ milhões e de $\mathrm{R} \$ 236,95$ milhões, para o cenário 1 e cenário 2 respectivamente, mostrando a sensibilidade do modelo CreditRisk+ aos valores de perda esperada, onde esses valores são maiores no cenário 2, determinando, conseqüentemente, maior montante de capital econômico alocado $(C E A)$. O CEA de cada cenário é obtido subtraindo-se a perda esperada $(P E)$ respectiva do valor do VaR. A Tabela 19 ilustra os resultados finais de cada cenário.

Tabela 19. Resultados obtidos em cada cenário, em R \$ milhões.

\begin{tabular}{ccccc}
\hline Cenário & Total do Portfólio & VaR & $P E$ & CEA \\
& & $(\mathrm{a})$ & $(\mathrm{b})$ & $(\mathrm{a}-\mathrm{b})$ \\
\hline 1 & $1.415,1$ & 172,8 & 6,5 & 166,3 \\
2 & $1.415,1$ & 237,0 & 22,5 & 214,4 \\
\hline
\end{tabular}

Fonte: dados da pesquisa.

Analisando-se a distribuição de $C E A$ para cada setor de atividade, observa-se uma maior concentração alocada para setores com clientes que possuem grande concentração e piores classificações. As Figura 13 e 14 mostram a relação entre o $C E A$ e seu próprio montante de risco de crédito por setor de atividade, para o cenário $1 \mathrm{e}$ cenário 2 , respectivamente. 


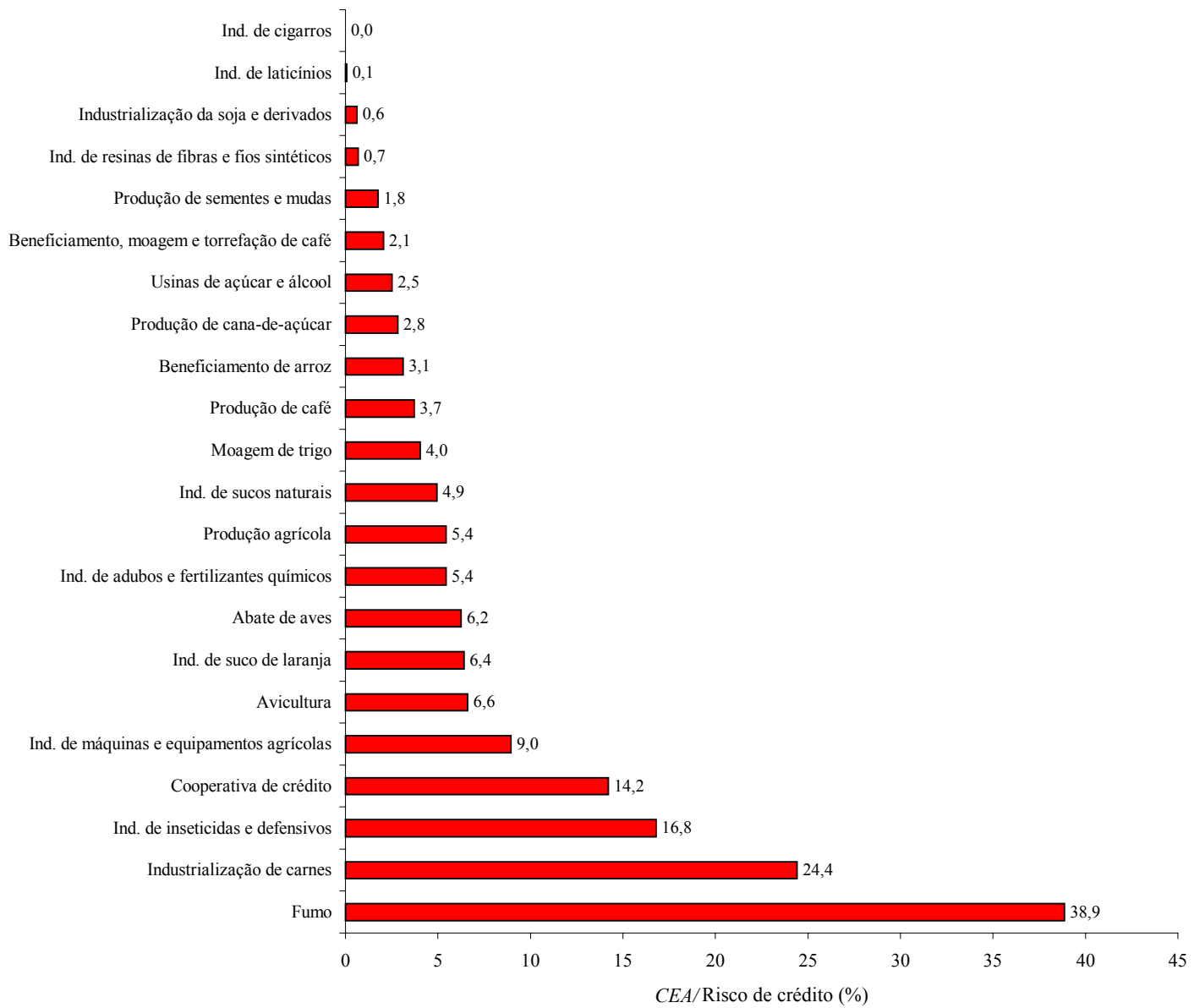

Figura 13 - Montante de $C E A$ sobre o risco de crédito de cada setor de atividade para o cenário 1 .

Fonte: dados da pesquisa. 


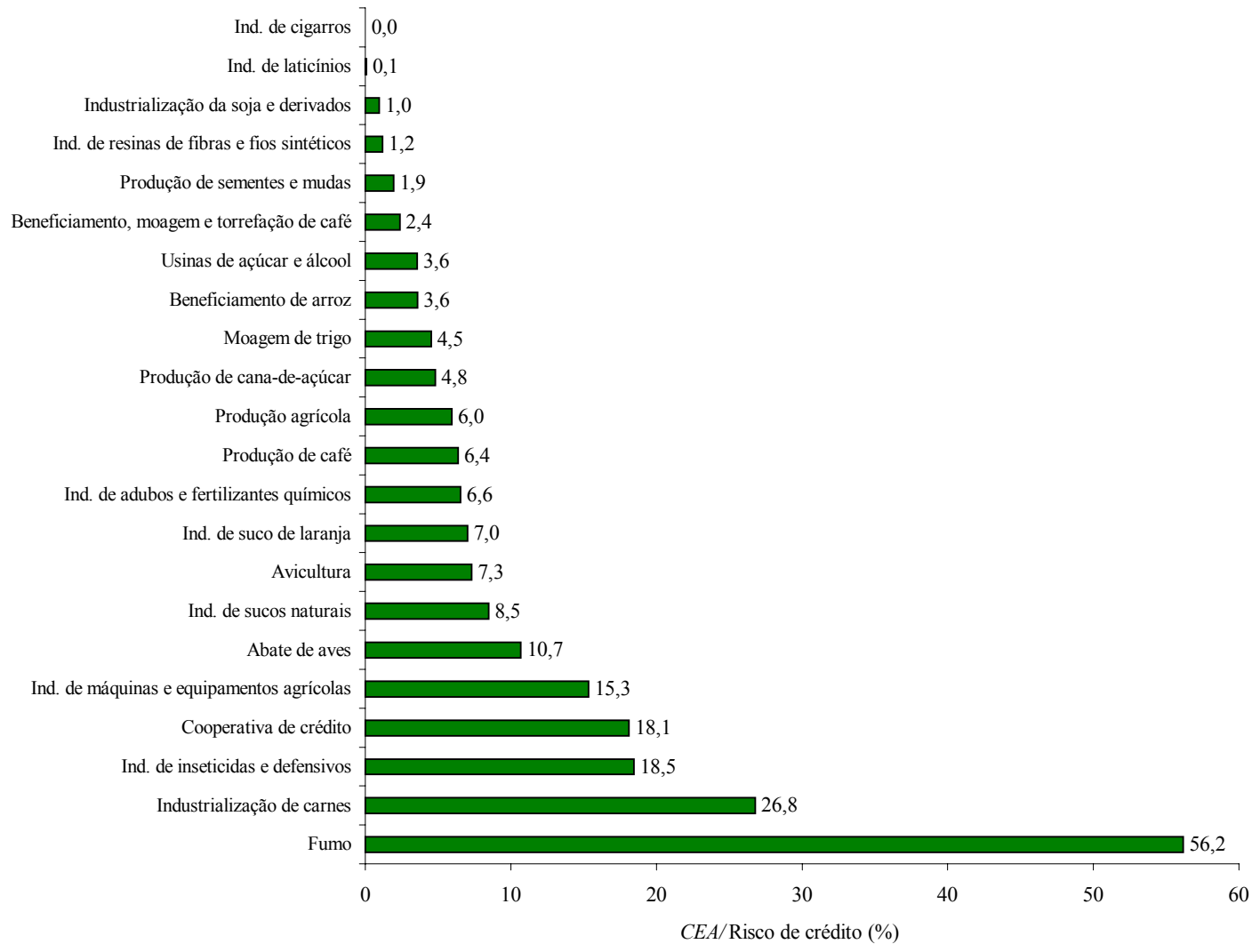

Figura 14 - Montante de $C E A$ sobre o risco de crédito de cada setor de atividade para o cenário 2.

Fonte: dados da pesquisa.

Observa-se que os setores de fumo e industrialização de carnes são os setores com maior percentual de $C E A$ sobre seu próprio risco de crédito em ambos cenários. Estes dois setores de atividade são responsáveis por 72,1\% e 74,2\% do total de $C E A$ do portfólio para o cenário 1 e cenário 2 , respectivamente.

Com os valores de $C E A$ e $P E$, determina-se a relação entre spread e RAROC utilizando-se as simplificações realizadas nas equações (34) e (35). Assim, a relação obtida para cada cenário é:

I) Cenário 1: RAROC $=\frac{\text { Spread }-R \$ 6,5 \text { milhoes }}{R \$ 166,3 \text { milhoes }}$ 
II) Cenário 2: RAROC $=\frac{\text { Spread }-R \$ 22,5 \text { milhoes }}{R \$ 214,4 \text { milhoes }}$

Estas relações permitem construir um gráfico tendo como abscissa o RAROC e como ordenada o spread. A Figura 15 ilustra estas relações para cada cenário.

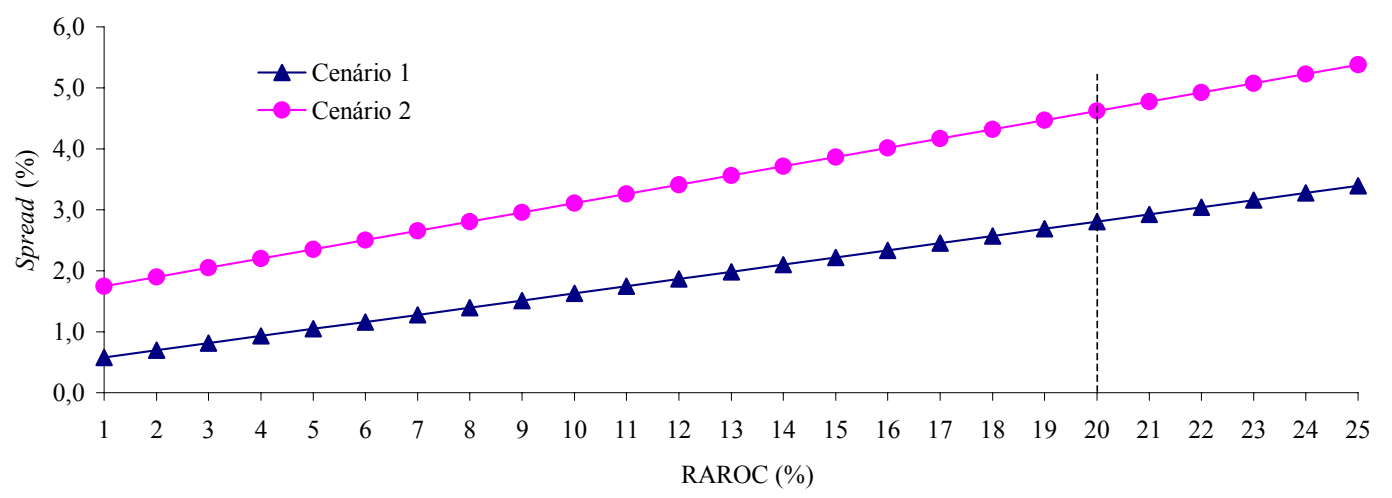

Figura 15 - Relação entre RAROC e spread para cada cenário.

Fonte: dados da pesquisa.

Comparando-se os valores de spread calculados, por exemplo, para um RAROC de 20\% a.a., seriam obtidos spreads de 2,81\% e 4,62\% para o cenário 1 e cenário 2, respectivamente. Estes resultados mostram que a aproximação de perdas em dinheiro, como é o caso do cenário 1, onde se aproxima o percentual de provisionamento, como se fossem eventos de inadimplência, subestima o $C E A$ e conseqüentemente o spread que deve ser cobrado para neutralizar as perdas esperadas e inesperadas, ao longo de um ano. Isso quando comparado ao cenário 2. A escolha do valor de RAROC a $20 \%$ a.a. é apenas ilustrativa. Um outro valor não muda a ordem dos spreads obtidos.

Utilizando-se o mesmo RAROC a $20 \%$ a.a. por setor de atividade, os cenários apresentam um spread diferenciado para cada setor, conforme ilustrados nas Figura 16 e 17 respectivamente para o cenário 1 e cenário 2. 


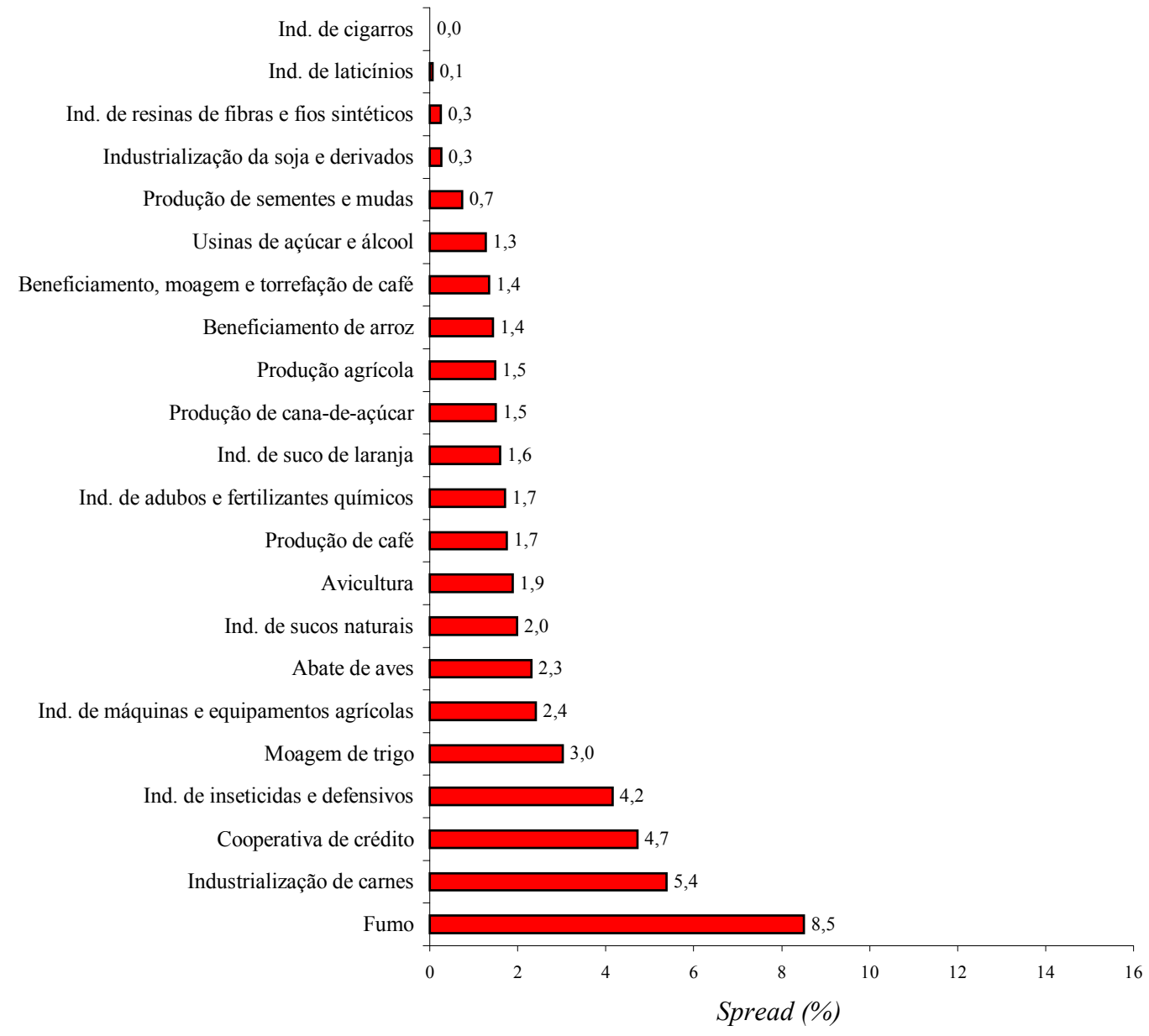

Figura 16 - Spread por setor de atividade $(\mathrm{RAROC}=20 \%$ a.a.) para o cenário 1.

Fonte: dados da pesquisa. 


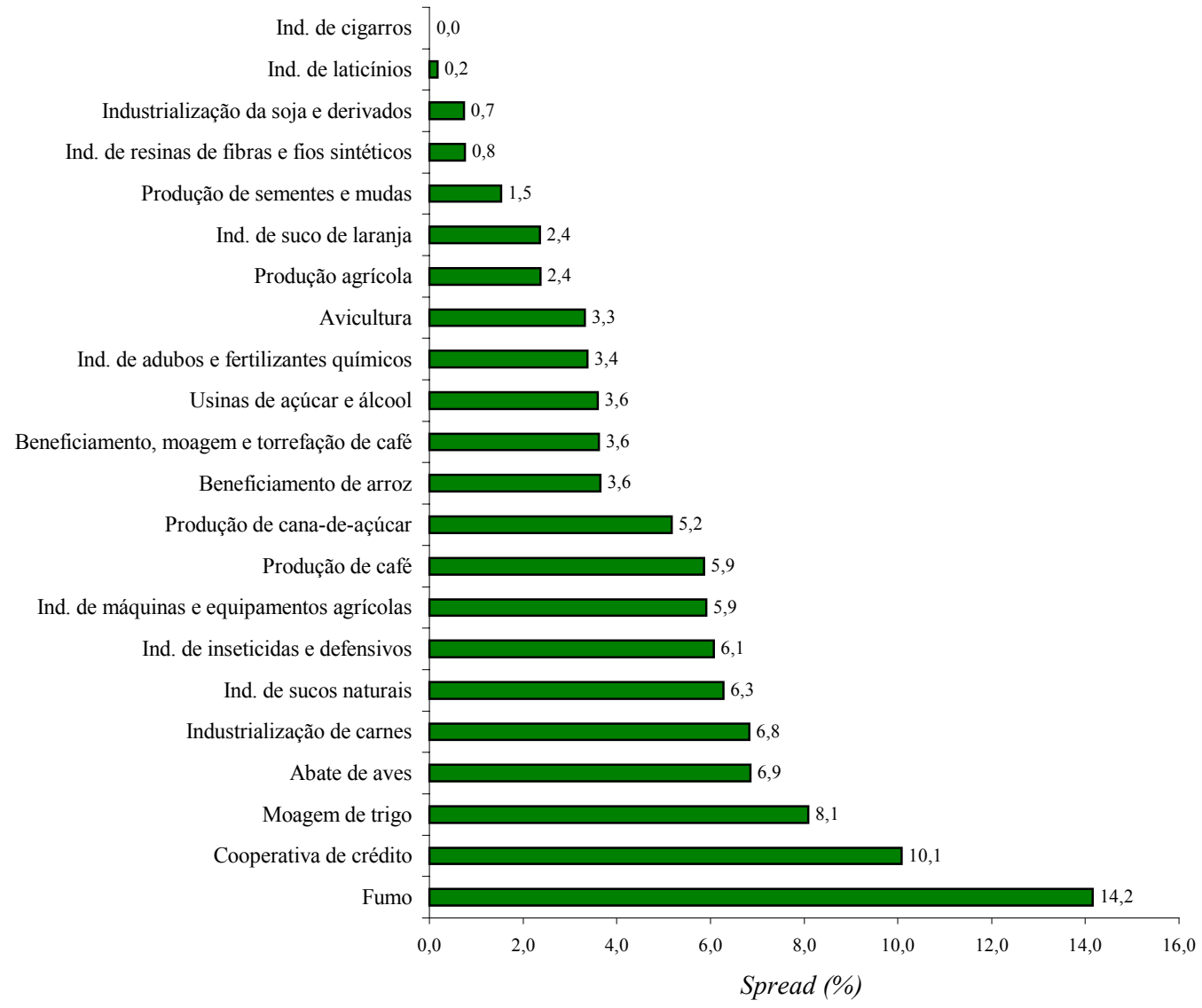

Figura 17 - Spread por setor de atividade (RAROC = 20\% a.a.) para o cenário 2.

Fonte: dados da pesquisa.

Observa-se que o $C E A$ leva em conta a classificação e a concentração de risco de crédito para distribuir o capital alocado por setor. Quando se calcula o spread, existe um componente a mais que é o montante de $P E$, fazendo com que alguns setores com menos $C E A$ tenham um spread mais elevado. Isto pode ser ilustrado, por exemplo, pelos setores denominados "abate de aves" e "moagem de trigo" que ocupam, respectivamente, oitava e décima segunda posições na relação $C E A /$ Risco de crédito (Figura 13) no cenário 1. Quando são analisados os spreads, estes setores de "moagem de trigo" e "abate de aves" ocupam, respectivamente, quinta e sétima posições, como evidencia a Figura 16. Isto mostra que, em alguns portfólios, é melhor uma concentração 
mais elevada, em um cliente com melhor classificação, do que diversificar o risco em clientes com pior classificação. Esta relação entre classificação e concentração é característica de cada portfólio, visto que o cenário 1 apresenta uma ordem decrescente de spread diferente do cenário 2 .

Observa-se pela Figura 16 que os spreads do cenário 1 variam de $0 \%$ até $8,5 \%$. Já pela Figura 17, os spreads do cenário 2 apresentam uma variação entre $0 \%$ e 14,2\%. Essas variações ilustram a influência do percentual de inadimplência associado a cada classificação.

Como forma de visualizar os resultados obtidos por tipo de modalidade temse as Figuras 18 e 19 para o cenário 1 e cenário 2, respectivamente.

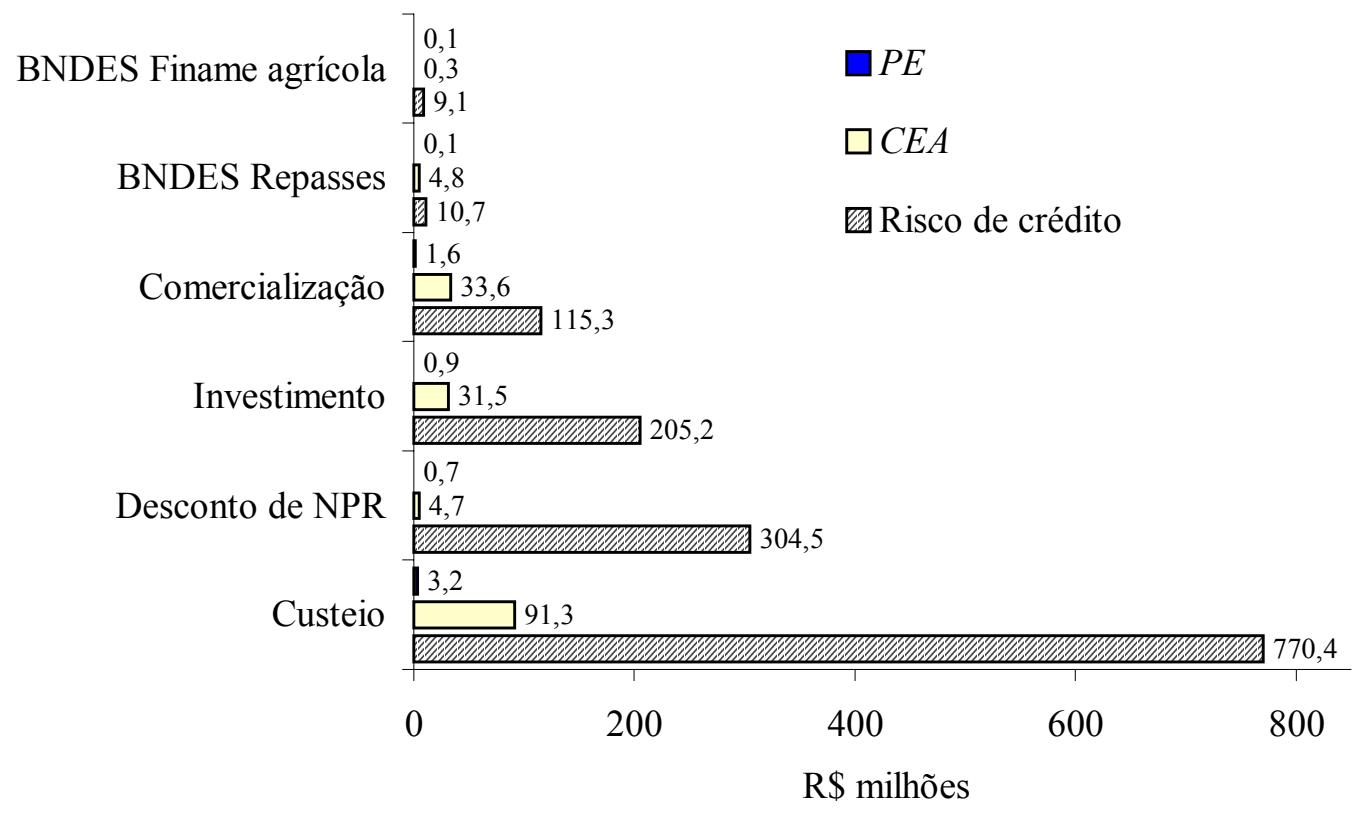

Figura 18 - Total de risco de crédito, $C E A$ e $P E$ para o cenário 1. Fonte: dados da pesquisa. 


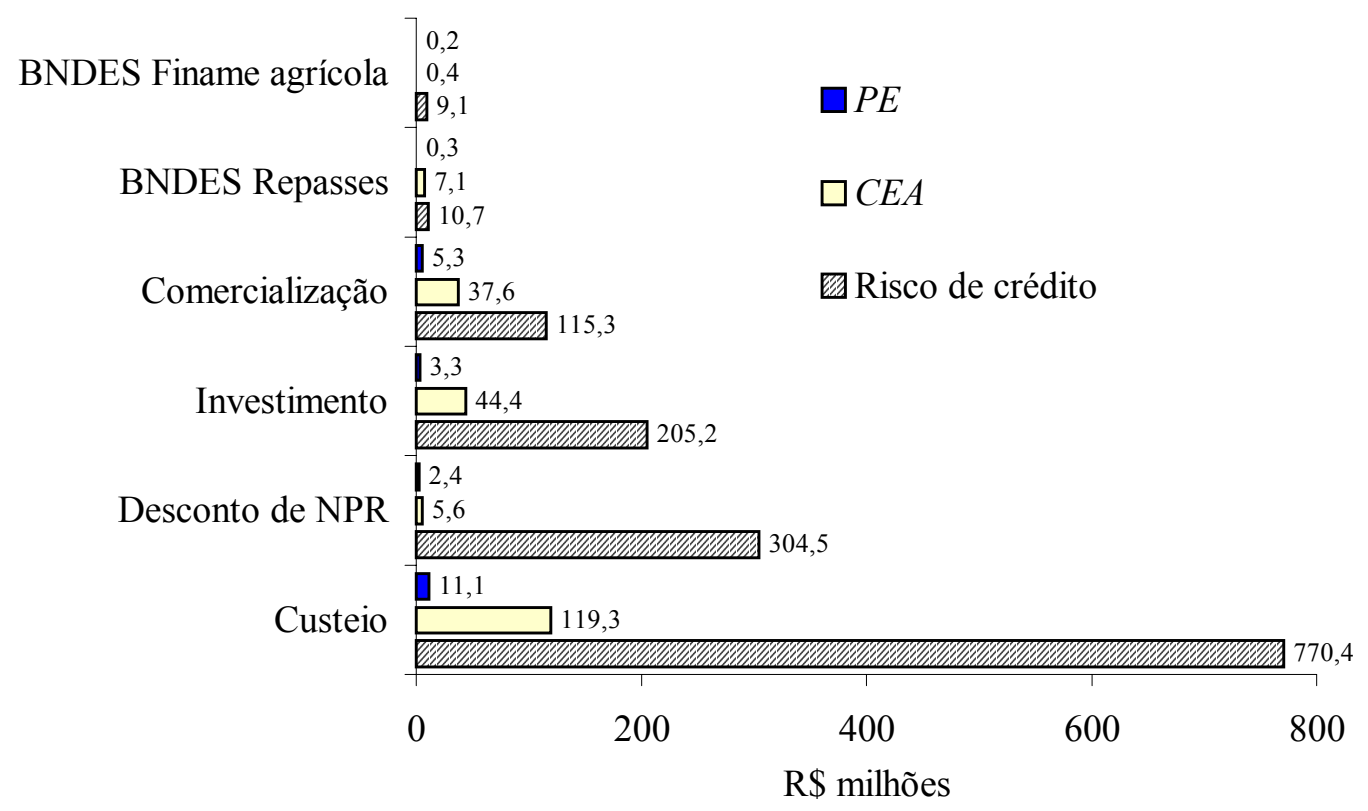

Figura 19 - Total de risco de crédito, $C E A$ e $P E$ para o cenário 2.

Fonte: dados da pesquisa.

Observa-se pelas Figuras 18 e 19 que a modalidade "custeio" possui maior volume de financiamentos (risco de crédito) com $\mathrm{R} \$ 770,4$ milhões. No entanto, possuem uma perda esperada e $C E A$ proporcionalmente baixos quando comparados as modalidades de "comercialização" e "BNDES repasses".

Utilizado-se novamente como exemplo, o RAROC a 20\% a.a., têm-se as Figuras 20 e 21 como forma de ilustrar o spread por modalidade para o cenário 1 e cenário 2 , respectivamente. 


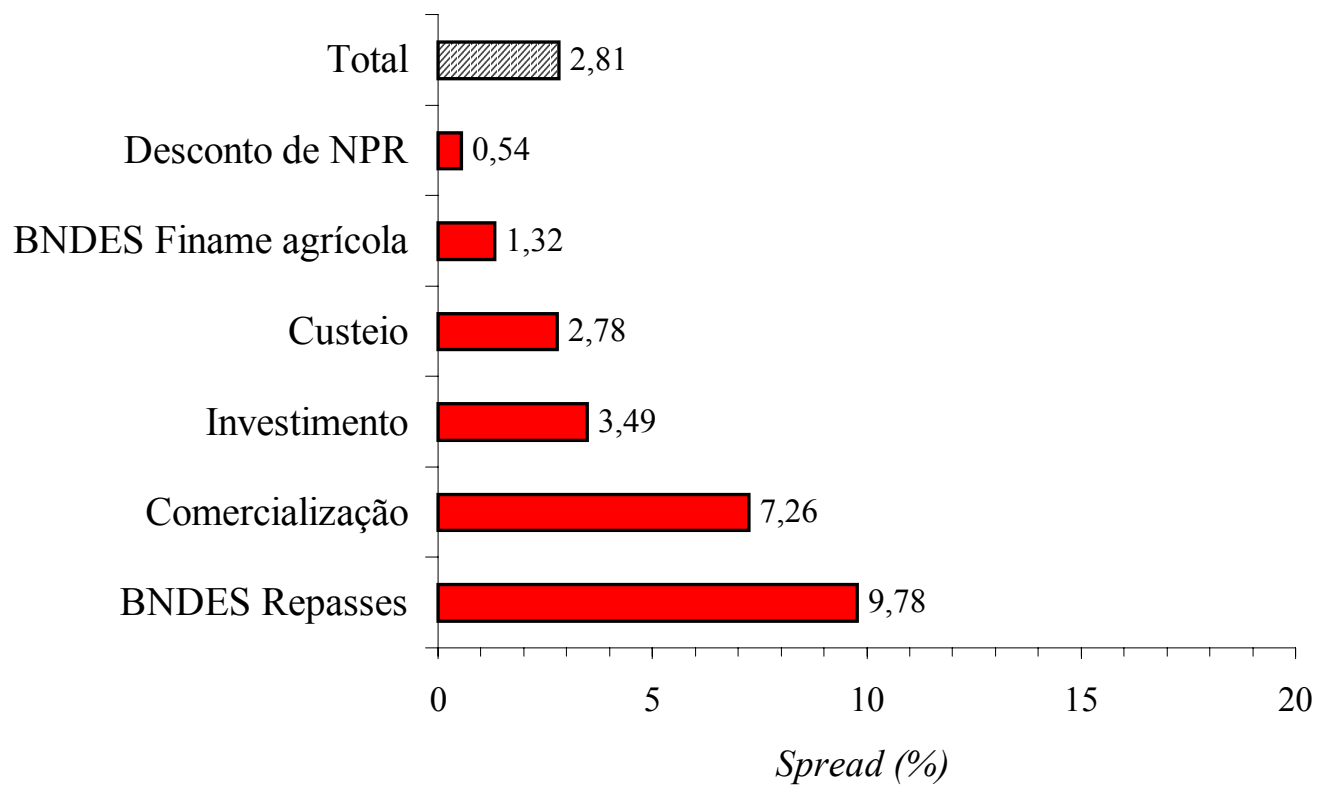

Figura 20 - Spread por modalidade para o cenário 1.

Fonte: dados da pesquisa.

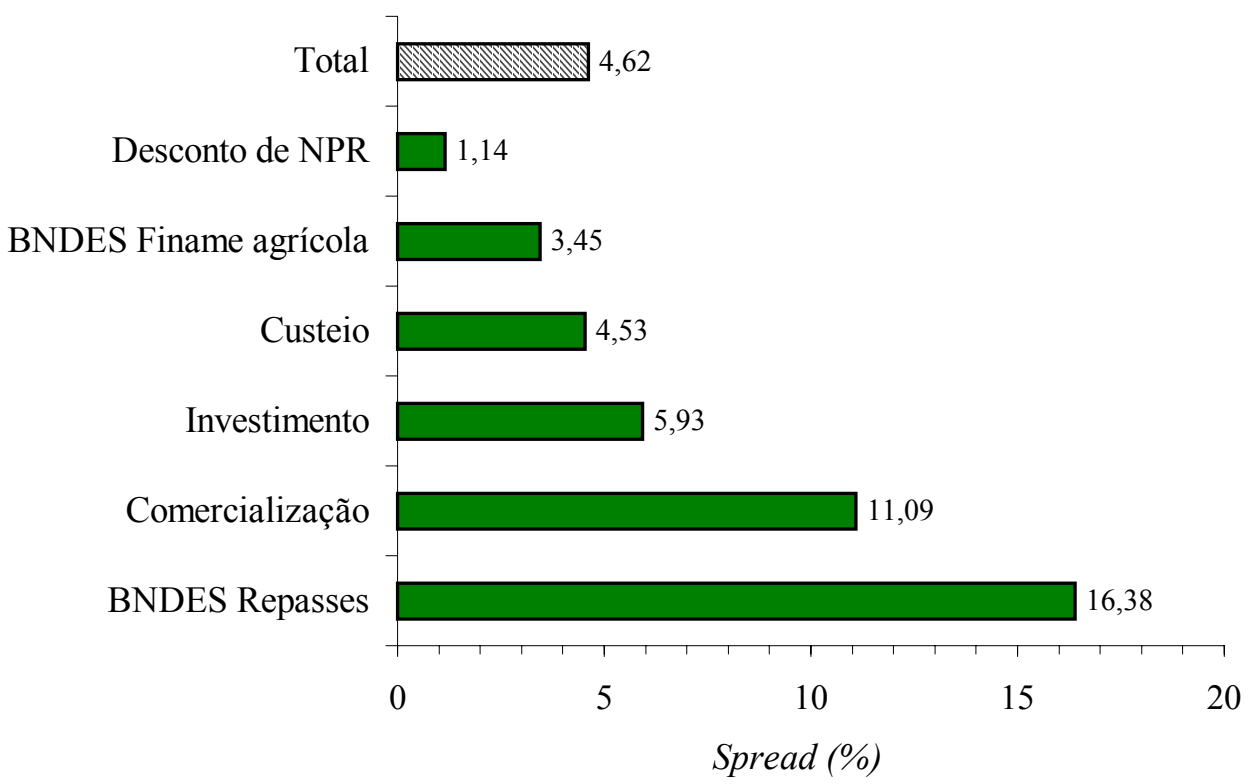

Figura 21 - Spread por modalidade para o cenário 2.

Fonte: dados da pesquisa. 
As Figuras 20 e 21 mostram a modalidade "desconto de NPR" com spreads de $0,54 \%$ e $1,14 \%$ para os cenários 1 e cenário 2, respectivamente. São os menores valores de spreads por tipo de modalidade, evidenciando uma menor probabilidade de perda. Isso se deve principalmente a característica deste tipo de operação, uma vez que a NPR se constitui em promessa de pagamento representativa do recebimento de um determinado produto objeto da comercialização. É um objeto de desconto por parte dos agentes financeiros, de modo a antecipar para o produtor ou cooperativa o valor de sua venda a prazo.

A ordem obtida para os spreads nas Figuras 20 e 21 mostra uma certa coerência, uma vez que a modalidade "BNDES Finame agrícola", segundo menor valor de spread, possui uma aplicação destinada à aquisição de máquinas, a qual fíca vinculada como garantia da operação, determinando uma classificação melhor para o cliente. A modalidade "custeio", terceiro menor spread, é composta por clientes "bons" que necessariamente possuem um histórico com a instituição, proporcionando um melhor direcionamento dos recursos. Para a modalidade "investimento", nem sempre é possível determinar a sua finalidade, proporcionando uma classificação conservadora para estes clientes. $\mathrm{Na}$ modalidade "comercialização" existem muitas operações de exportação vinculadas a taxas de câmbio, aumentando o risco da operação. A modalidade "BNDES Repasses", que apesar de representar apenas $1 \%$ do total do portfólio, possui maior valor de spread, ocasionado principalmente pela concessão a clientes que não possuem histórico de transações com a instituição, mas que se utilizam a mesma para obter as linhas oferecidas pelo BNDES. 


\section{CONCLUSÕES}

O presente trabalho destaca os principais conceitos envolvidos nos riscos financeiros enfrentados pela atividade bancária, evidenciando o risco de crédito e as características necessárias para sua quantificação. A descrição das etapas de administração de um portfólio de crédito mostrou a necessidade de um processo consistente de classificação de clientes, embasado nas características definidas pela Resolução 2682 do BACEN, de forma a obter uma classificação precisa do empréstimo concedido.

Dentre as quatro metodologias analisadas para quantificação de risco de crédito, a metodologia do CreditRisk+ mostrou-se mais compatível com a realidade das instituições financeiras brasileiras. Isso tornou-se evidente porque o modelo Credit Metrics, além de necessitar de uma matriz de probabilidades de transição, necessita de mercados secundários líquidos de crédito, o que não ocorre no Brasil. No modelo KMV são necessários mercados locais de ações e opções de todas as empresas presentes no portfólio de crédito. Estas características também não são observáveis no mercado brasileiro. Finalmente a metodologia utilizada pelo Credit Portfolio View mostrou a necessidade de um histórico de estabilidade econômica para modelar e reproduzir o efeito das variáveis macroeconômicas. Já o CreditRisk+ assume que todos os contratos de empréstimo são mantidos até o vencimento, de forma que o pagamento ou a inadimplência ocorrem apenas no final do contrato. Essas particularidades, presentes no portfólio de crédito das instituições financeiras brasileiras, permitem a utilização de uma fórmula fechada no cálculo do $\mathrm{VaR}$ e do $C E A$. Além disso, sua fórmula analítica permite a construção de cenários que servem de embasamento para tomada de decisão. 
O cálculo do RAROC permitiu observar que a utilização do $C E A$ de maneira isolada como instrumento de gerenciamento de risco, nem sempre determina uma melhor alocação de recursos, mas simplismente determina o montante necessário para cobrir as perdas inesperadas. Foi possível também determinar a influência da probabilidade de inadimplência utilizada em cada classificação, mostrando-se a diferença, entre os dois cenários, do montante de $C E A$ e principalmente no spread necessário para cobrir o risco de crédito. Observa-se a importância de uma mensuração precisa da expectativa de perda associada a cada classificação por parte das instituições financeiras, bem como o conhecimento do processo de produção do tomador de empréstimo, avaliando qualitativamente o risco de crédito envolvido em sua atividade.

O portfólio de financiamentos rurais e agroindustriais, utilizado no presente trabalho, mostrou-se bastante concentrado em poucas empresas, fazendo com que o modelo CreditRisk+ penalizasse os clientes com volume de crédito elevado, alocando maior quantidade de capital. Isso pôde ser observado no setor de fumo, com total de financiamentos em $\mathrm{R} \$ 202,9$ milhões e $C E A$ de $\mathrm{R} \$ 78,9$ milhões e $\mathrm{R} \$ 114,0$ milhões para o cenário 1 e cenário 2 , respectivamente. A matriz de migração de clientes, utilizada na determinação da probabilidade de inadimplência de cada classificação do cenário 2 , foi obtida com apenas 713 clientes para o período de 2000 a 2002. Essa matriz, apesar da amostra limitada de dados, permite observar que existe uma volatilidade maior para clientes classificados como "B" e "C". Além disso, observa-se que o percentual de inadimplência, obtido para cada classificação, é maior do que aquele utilizado no cenário 1 quando ocorre a aproximação do percentual de provisionamento determinado pelo BACEN para eventos de inadimplência. Esse procedimento realizado no cenário 1 tem sido utilizado por algumas instituições financeiras. Isso mostra novamente a necessidade de mensurar a perda real por classificação para que não ocorra excesso ou escassez de capital econômico alocado.

As modalidades de financiamentos rurais e agroindustriais de "custeio" e “desconto de NPR” são responsáveis por cerca de 75\% do total do portfólio. No entanto, 
estas modalidades apresentam a necessidade de um spread menor para cobrir as perdas esperadas e inesperadas com crédito, sinalizando uma composição de clientes com melhor classificação. Observa-se também que os menores spreads ocorrem principalmente nos setores de indústria de cigarros, laticínios, soja e derivados, e resinas de fibras e fios sintéticos. Já os setores diretamente vinculados à produção como fumo e moagem de trigo, tiveram maiores spreads.

Dado que o portfólio utilizado representa cerca de $10 \%$ do total de financiamentos rurais e agroindustriais que se encontrava alocado no sistema financeiro privado em março de 2003, é possível observar o tipo de tratamento qualitativo e quantitativo que as instituições se utilizam para mensurar o risco de crédito. No entanto, as empresas com operações classificadas como "AA" não tiveram nenhum capital econômico alocado e consequentemente não se determinou nenhum valor de spread para estas operações. Isso significa apenas que o risco de crédito, ou seja, a perda esperada para estes clientes foi considerada nula. A matriz de migração de clientes evidenciou que após um ano, nenhum cliente com classificação "AA" havia migrado para classificações piores do que "A". No entanto, a instituição detentora do crédito pode cobrar um spread para cobrir outros custos e tarifas que não foram considerados no equacionamento do RAROC. A utilização de um valor de $20 \%$ a.a. para o RAROC proporcionou a distribuição dos spreads para cada setor de atividade. No entanto, sua escolha foi feita apenas para melhor ilustrar o portfólio. A alteração deste valor não altera a ordem dos spreads encontrados para cada setor ou modalidade de financiamento.

Como forma de minimizar os riscos envolvidos em financiamentos rurais e agroindustriais é necessário um melhor entendimento do processo de produção deste setor econômico. Apesar de muitos gerenciadores de carteiras acreditarem que este setor apresenta um maior risco de crédito, existe a possibilidade de dividir esse risco em duas etapas como forma de minimizá-los. Uma primeira etapa seria através do mapeamento do processo de produção, certificando-se que produtores e empresas rurais utilizam-se de técnicas modernas ou dentro de padrões aceitáveis no plantio, tratos culturais, colheita e comercialização. Dessa forma, os gerenciadores de carteiras poderiam 
minimizar o risco de performance ou risco de produção. Quando esse risco é minimizado, resta apenas o risco de crédito, ou risco de inadimplência, considerado como segunda etapa. Como esse risco também já existe em outros setores da economia, as instituições financeiras possuem um certo nível de controle das variáveis envolvidas. Assim, é necessário criar um banco de dados com clientes rurais e agroindustriais, para possibilitar a concessão de crédito. Consequentemente, as instituições podem diponibilizar outros produtos e serviços, fortalecendo o relacionamento com o cliente. Uma outra abordagem que a instituição financeira pode prover é o suporte às operações rurais e agroindustriais que necessitam conhecimento em mercados de derivativos agropecuários, travas de câmbio para exportação, dentre outros, diminuindo o risco de produção.

A generalização dos resultados necessita da análise de novos portfólios para confirmação dos valores obtidos. Cabe destacar que o presente estudo não considerou uma volatilidade das classificações no modelo CreditRisk+. Num segundo estágio, o modelo permite que sejam adicionadas variações no percentual de perdas de cada classificação. Isso provavelmente aumentaria o volume de capital necessário para cobrir as perdas com crédito. Estudos futuros podem abordar este tipo de situação, mostrando a sensibilidade da metodologia. 
ANEXOS 
ANEXO A - Resolução 2.293.

Dispõe sobre a exigibilidade de aplicações em credito rural (MCR 6-2).

O BANCO CENTRAL DO BRASIL, na forma do art. 9. da Lei n. 4.595, de 31.12.64, torna publico que o CONSELHO MONETARIO NACIONAL, em sessão realizada em 27.06.96, tendo em vista as disposições do art. 4., inciso VI, da citada Lei, e dos arts. 4. e 14 da Lei n. 4.829, de 05.11.65, R E S O L V E U:

Art. 1. Restabelecer a exigibilidade de aplicação em credito rural de que trata o Manual de Credito Rural (MCR 6-2) em 25\% (vinte e cinco por cento) do saldo médio diário das rubricas contábeis de recursos a vista sujeitos ao recolhimento compulsório, observado o seguinte cronograma:

I - agosto/96: 18\% (dezoito por cento);

II - setembro/96: 19\% (dezenove por cento);

III - outubro/96: 20\% (vinte por cento);

IV - novembro/96: $21 \%$ (vinte e um por cento);

V - dezembro/96: 22\% (vinte e dois por cento);

VI - janeiro/97: 25\% (vinte e cinco por cento).

Parágrafo único. Para efeito do disposto neste artigo, o primeiro período de calculo e o mês de julho de 1996.

Art. 2. O Banco Central do Brasil poderá baixar as normas e adotar as medidas julgadas necessárias a execução do disposto nesta Resolução.

Art. 3. Esta Resolução entra em vigor na data de sua publicação.

Art. 4. Fica revogada, a partir de 01.08.96, a Resolução n. 2.182, de 20.07.95.

Brasília, 28 de junho de 1996.

Gustavo Jorge Laboissiere Loyola

Presidente 


\section{ANEXO B - Resolução 2.682.}

Dispõe sobre critérios de classificação das operações de credito e regras para constituição de provisão para créditos de liquidação duvidosa.

O BANCO CENTRAL DO BRASIL, na forma do art. 9. da Lei n. 4.595, de 31 de dezembro de 1964, torna publico que o CONSELHO MONETARIO NACIONAL, em sessão realizada em 21 de dezembro de 1999, com base no art. 4., incisos XI e XII, da citada Lei, R E S O L V E U:

Art. 1. Determinar que as instituições financeiras e demais instituições autorizadas a funcionar pelo Banco Central do Brasil devem classificar as operações de credito, em ordem crescente de risco, nos seguintes níveis:

$$
\begin{aligned}
& \text { I - nivel AA; } \\
& \text { II - nivel A; } \\
& \text { II - nivel B; } \\
& \text { IV - nivel C; } \\
& \text { V - nivel D; } \\
& \text { VI - nivel E; } \\
& \text { VII - nivel F; } \\
& \text { VIII - nivel G; } \\
& \text { IX - nivel H. }
\end{aligned}
$$

Art. 2. A classificação da operação no nível de risco correspondente e de responsabilidade da instituição detentora do credito e deve ser efetuada com base em critérios consistentes e verificáveis, amparada por informações internas e externas, contemplando, pelo menos, os seguintes aspectos:

I - em relação ao devedor e seus garantidores:
a) situação econômico-financeira;
b) grau de endividamento;
c) capacidade de geração de resultados;
d) fluxo de caixa;
e) administração e qualidade de controles;
f) pontualidade e atrasos nos pagamentos;
g) contingências;
h) setor de atividade econômica;
i) limite de credito; 
II - em relação a operação:

a) natureza e finalidade da transação;

b) características das garantias, particularmente quanto a suficiência e liquidez;

c) valor.

Parágrafo único. A classificação das operações de credito de titularidade de pessoas físicas deve levar em conta, também, as situações de renda e de patrimônio bem como outras informações cadastrais do devedor.

Art. 3. A classificação das operações de credito de um mesmo cliente ou grupo econômico deve ser definida considerando aquela que apresentar maior risco, admitindo-se excepcionalmente classificação diversa para determinada operação, observado o disposto no art. 2., inciso II.

Art. 4. A classificação da operação nos níveis de risco de que trata o art. 1. deve ser revista, no mínimo:

I - mensalmente, por ocasião dos balancetes e balanços, em função de atraso verificado no pagamento de parcela de principal ou de encargos, devendo ser observado o que segue:

a) atraso entre 15 e 30 dias: risco nível B, no mínimo;

b) atraso entre 31 e 60 dias: risco nível C, no mínimo;

c) atraso entre 61 e 90 dias: risco nível D, no mínimo;

d) atraso entre 91 e 120 dias: risco nível E, no mínimo;

e) atraso entre 121 e 150 dias: risco nível F, no mínimo;

f) atraso entre 151 e 180 dias: risco nível G, no mínimo;

g) atraso superior a 180 dias: risco nível $\mathrm{H}$;

II - com base nos critérios estabelecidos nos arts. 2. e 3.:

a) a cada seis meses, para operações de um mesmo cliente ou grupo econômico cujo montante seja superior a 5\% (cinco por cento) do patrimônio liquido ajustado;

b) uma vez a cada doze meses, em todas as situações, exceto na hipótese prevista no art. 5.

Parágrafo 1. As operações de adiantamento sobre contratos de cambio, as de financiamento a importação e aquelas com prazos inferiores a um mês, que apresentem atrasos superiores a trinta dias, bem como o adiantamento a depositante a partir de trinta dias de sua ocorrência, devem ser classificados, no mínimo, como de risco nível G.

Parágrafo 2. Para as operações com prazo a decorrer superior a 36 meses admite-se a contagem em dobro dos prazos previstos no inciso I. 
Parágrafo 3. O não atendimento ao disposto neste artigo implica a reclassificação das operações do devedor para o risco nível $\mathrm{H}$, independentemente de outras medidas de natureza administrativa.

Art. 5. As operações de credito contratadas com cliente cuja responsabilidade total seja de valor inferior a $\mathrm{R} \$ 50.000,00$ (cinqüenta mil reais) podem ter sua classificação revista de forma automática unicamente em função dos atrasos consignados no art. 4., inciso I, desta Resolução, observado que deve ser mantida a classificação original quando a revisão corresponder a nível de menor risco.

Parágrafo 1. O Banco Central do Brasil poderá alterar o valor de que trata este artigo.

Parágrafo 2. O disposto neste artigo aplica-se as operações contratadas ate 29 de fevereiro de 2000, observados o valor referido no caput e a classificação, no mínimo, como de risco nível A.

Art. 6. A provisão para fazer face aos créditos de liquidação duvidosa deve ser constituída mensalmente, não podendo ser inferior ao somatório decorrente da aplicação dos percentuais a seguir mencionados, sem prejuízo da responsabilidade dos administradores das instituições pela constituição de provisão em montantes suficientes para fazer face a perdas prováveis na realização dos créditos: risco nível A;

I - 0,5\% (meio por cento) sobre o valor das operações classificadas como de

II - 1\% (um por cento) sobre o valor das operações classificadas como de risco nível B;

III - 3\% (três por cento) sobre o valor das operações classificadas como de risco nível $\mathrm{C}$; risco nível D;

IV - 10\% (dez por cento) sobre o valor das operações classificados como de risco nível E;

V - 30\% (trinta por cento) sobre o valor das operações classificados como de

VI - 50\% (cinqüenta por cento) sobre o valor das operações classificados como de risco nível $\mathrm{F}$;

VII - 70\% (setenta por cento) sobre o valor das operações classificados como de risco nível $\mathrm{G}$;

VIII - 100\% (cem por cento) sobre o valor das operações classificadas como de risco nível $\mathrm{H}$.

Art. 7. A operação classificada como de risco nível $\mathrm{H}$ deve ser transferida para conta de compensação, com o correspondente debito em provisão, apos decorridos 
seis meses da sua classificação nesse nível de risco, não sendo admitido o registro em período inferior.

Parágrafo único. A operação classificada na forma do disposto no caput deste artigo deve permanecer registrada em conta de compensação pelo prazo mínimo de cinco anos e enquanto não esgotados todos os procedimentos para cobrança.

Art. 8. A operação objeto de renegociação deve ser mantida, no mínimo, no mesmo nível de risco em que estiver classificada, observado que aquela registrada como prejuízo deve ser classificada como de risco nível $H$.

Parágrafo 1. Admite-se a reclassificação para categoria de menor risco quando houver amortização significativa da operação ou quando fatos novos relevantes justificarem a mudança do nível de risco.

Parágrafo 2. O ganho eventualmente auferido por ocasião da renegociação deve ser apropriado ao resultado quando do seu efetivo recebimento.

Parágrafo 3. Considera-se renegociação a composição de divida, a prorrogação, a novação, a concessão de nova operação para liquidação parcial ou integral de operação anterior ou qualquer outro tipo de acordo que implique na alteração nos prazos de vencimento ou nas condições de pagamento originalmente pactuadas.

Art. 9. E vedado o reconhecimento no resultado do período de receitas e encargos de qualquer natureza relativos a operações de credito que apresentem atraso igual ou superior a sessenta dias, no pagamento de parcela de principal ou encargos.

Art. 10. As instituições devem manter adequadamente documentadas sua política e procedimentos para concessão e classificação de operações de credito, os quais devem ficar a disposição do Banco Central do Brasil e do auditor independente.

Parágrafo único. A documentação de que trata o caput deste artigo deve evidenciar, pelo menos, o tipo e os níveis de risco que se dispõe a administrar, os requerimentos mínimos exigidos para a concessão de empréstimos e o processo de autorização.

Art. 11. Devem ser divulgadas em nota explicativa as demonstrações financeiras informações detalhadas sobre a composição da carteira de operações de credito, observado, no mínimo: econômica;

I - distribuição das operações, segregadas por tipo de cliente e atividade

II - distribuição por faixa de vencimento;

III - montantes de operações renegociadas, lançados contra prejuízo e de operações recuperadas, no exercício. 
Art. 12. O auditor independente deve elaborar relatório circunstanciado de revisão dos critérios adotados pela instituição quanto a classificação nos níveis de risco e de avaliação do provisionamento registrado nas demonstrações financeiras.

Art. 13. O Banco Central do Brasil poderá baixar normas complementares necessárias ao cumprimento do disposto nesta Resolução, bem como determinar:

I - reclassificação de operações com base nos critérios estabelecidos nesta Resolução, nos níveis de risco de que trata o art.1.;

II - provisionamento adicional, em função da responsabilidade do devedor junto ao Sistema Financeiro Nacional;

III - providencias saneadoras a serem adotadas pelas instituições, com vistas a assegurar a sua liquidez e adequada estrutura patrimonial, inclusive na forma de alocação de capital para operações de classificação considerada inadequada;

IV - alteração dos critérios de classificação de créditos, de contabilização e de constituição de provisão; financeiras;

$\mathrm{V}$ - teor das informações e notas explicativas constantes das demonstrações

VI - procedimentos e controles a serem adotados pelas instituições.

Art. 14. O disposto nesta Resolução se aplica também as operações de arrendamento mercantil e a outras operações com características de concessão de credito.

Art. 15. As disposições desta Resolução não contemplam os aspectos fiscais, sendo de inteira responsabilidade da instituição a observância das normas pertinentes.

Art. 16. Esta Resolução entra em vigor na data da sua publicação, produzindo efeitos a partir de 1. de marco de 2000, quando ficarão revogadas as Resoluções n.s 1.748, de 30 de agosto de 1990, e 1.999, de 30 de junho de 1993, os arts. 3. e 5. da Circular n. 1.872, de 27 de dezembro de 1990, a alínea "b" do inciso II do art. 4. da Circular n. 2.782, de 12 de novembro de 1997, e o Comunicado n. 2.559, de 17 de outubro de 1991.

Brasilia, 21 de dezembro de 1999

Arminio Fraga Neto

Presidente 


\title{
ANEXO C - Resolução 2.399.
}

\author{
Altera a formula de calculo do \\ patrimônio liquido de que trata o \\ Regulamento \\ Anexo IV a Resolução n 2.099, de \\ 17.08.94.
}

O BANCO CENTRAL DO BRASIL, na forma do art. 9 da Lei n 4.595, de 31.12.64, torna publico que o Conselho Monetário Nacional, em sessão realizada em 25.06.97, tendo em vista o disposto no art. 4 , incisos VIII, XI e XXII da referida Lei, R E S O L V E U:

Art. 1. Alterar o art. 2. do Regulamento Anexo IV a Resolução n. 2.099, de 17.08.94, com a redação dada pela Resolução n. 2.262, de 28.03.96, que passa a vigorar com a seguinte redação:

"Art. 2. O calculo do valor do patrimônio liquido referido no artigo anterior obedecera a seguinte formula:

$$
\mathrm{PLE}=\mathrm{F}_{\mathrm{i}=1}^{\mathrm{n}} \mathrm{RCDi}+\mathrm{F} \text {.Apr , onde: }
$$

PLE = patrimônio liquido exigido;

$\mathrm{F}^{\prime}=$ fator aplicável ao risco de credito das operações de "swap" = 0,16;

$\mathrm{RCDi}=$ risco de credito da i-ésima operação de "swap" inscrita na conta 3.0.6.10.60-4 do COSIF, consistente na ponderação do valor de referencia da operação no momento da respectiva contratação (VNi) pelo fator de risco potencial correspondente, considerado seu prazo a decorrer, dado pela formula:

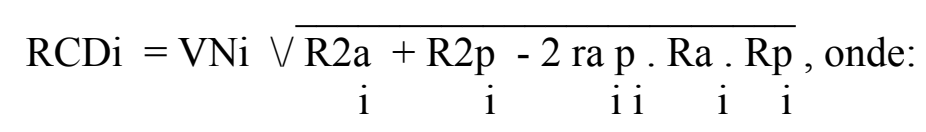

$\mathrm{Ra}=$ risco do referencial ativo da i-esima operação;

$$
\text { i }
$$

$\mathrm{Rp}$ = risco do referencial passivo da i-esima operação;

$\mathrm{i}$

ra $\mathrm{p}=$ correlação dos referenciais ativo e passivo da i-esima operação;

$$
\text { i i }
$$

$\mathrm{F}=$ fator aplicável as operações ativas ponderadas pelo risco $(\mathrm{Apr})=0,10$, observado o estabelecido no art. 1. da Resolução n 2.212, de 16.11.95; 
Apr $=$ Ativo ponderado pelo risco $=$ total do produto dos títulos do Ativo Circulante e Realizável a Longo Prazo (código 1.0.0.00.00-7 do COSIF) pelos fatores de risco correspondentes + produto do Ativo Permanente (código 2.0.0.00.00-4 do COSIF) pelo fator de risco correspondente + produto dos títulos de Coobrigacoes e Riscos em Garantias Prestadas (código 3.0.1.00.00-4 do COSIF) pelos fatores de risco correspondentes.

"Parágrafo 1. Para efeito da apuração do risco das operações de 'swap' (RCDi), os valores referentes aos riscos dos referenciais objeto, bem como as suas correlações, serão calculados e divulgados na forma a ser definida pelo Banco Central do Brasil.

"Parágrafo 2. Para efeito da apuração do Apr, os riscos das operações ativas obedecerão a classificação constante da tabela anexa a este Regulamento.

"Parágrafo 3. Fica o Banco Central do Brasil autorizado a:

I - alterar a tabela referida no parágrafo anterior, bem como os fatores $\mathrm{F}$ e $\mathrm{F}^{\prime}$ constantes da formula estabelecida no 'caput' deste artigo;

II - atribuir fatores de risco a novos títulos contábeis criados no COSIF."

Art. 2. Não integram a base de calculo do patrimônio liquido exigido (PLE):

I - as operações realizadas em sistemas com garantia administrados por bolsas de valores ou de mercadorias e de futuros;

II - as operações nas quais a instituição atue exclusivamente como intermediadora, não assumindo quaisquer direitos ou obrigações com a contraparte.

Art. 3. Alterar o art. 1., "caput", da Resolução n. 2.212, de 16.11.95, que passa a vigorar com a seguinte redação:

"Art. 1. As instituições autorizadas a funcionar pelo Banco Central do Brasil, a partir de 17.11.95, devem manter valor de patrimônio liquido ajustado compatível com o grau de risco da estrutura de seus ativos, de acordo com o disposto no Regulamento Anexo IV a Resolução n. 2.099, de 17.08.94, observados os seguintes valores para o fator (F) aplicável as operações ativas ponderadas pelo risco (Apr):

I - durante os 2 (dois) primeiros anos: $\mathrm{F}=0,32$;

II - de 2 (dois) a 4 (quatro) anos: $\mathrm{F}=0,24$;

III - de 4 (quatro) a 6 (seis) anos: $\mathrm{F}=0,16$;

IV - a partir de 6 (seis) anos, o valor atribuído no art. 2. do Regulamento Anexo IV a Resolução n. 2.099, de 17.08.94.

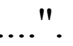

Art. 4. Alterar o art. 3., inciso IV, da Resolução n. 2.193, de 31.08.95, que passa a vigorar com a seguinte redação: 
"Art. 3.

IV - devem manter valor de patrimônio liquido ajustado compatível com o grau de risco da estrutura de seus ativos, de acordo com o disposto no Regulamento Anexo IV da Resolução 2.099, de 17.08.94, observado o valor de 0,15 para o fator $(\mathrm{F})$ aplicável as operações ativas ponderadas pelo risco (Apr)."

Art. 5. O Banco Central do Brasil poderá baixar recomendações voltadas para a avaliação e para o gerenciamento dos riscos das instituições financeiras e demais instituições por ele autorizadas a funcionar, de molde a propiciar melhor compreensão e a implementação dos instrumentos necessários ao controle e a supervisão das operações financeiras, em geral, e daquelas realizadas nos mercados de derivativos, em particular.

Art. 6. Esta Resolução entra em vigor em 01.08.97, quando ficara revogada a Resolução n 2.262, de 28.03.96.

Parágrafo único. Fica admitida, ate 31.12.97, eventual insuficiência do patrimônio liquido ajustado da instituição em decorrência da aplicação da metodologia de calculo ora estabelecida, vedada, nesse caso, a contratação de quaisquer novas operações que onerem referida insuficiência.

Brasília, 25 de junho de 1997

Gustavo Jorge Laboissiere Loyola

Presidente 


\section{REFERÊNCIAS BIBLIOGRÁFICAS}

ABE, E.R. Modelos de risco de crédito: estudo de caso do modelo KMV adequado ao mercado brasileiro. São Paulo, 2002. 111p. Dissertação (M.S.) - Faculdade de Economia e Administração, Universidade de São Paulo.

ALEXANDER, G.J.; FRANCIS, J.C. Portfolio analysis. 2.ed. New York: PrenticeHall, 1986. 306p.

ARAGÃO, C.S.L.; CARVALHO, L.E.Z.L.; BARROS, M.O. Análise do risco de uma carteira de crédito por meio de simulação de Monte Carlo. Resenha BM\&F, n.152, p.49-56, nov./dez. 2002.

BANCO CENTRAL DO BRASIL. Anuário estatístico do crédito rural 2001. http://www.bcb.gov.br/?relrural2001 (10 out. 2003)

BANCO CENTRAL DO BRASIL. Séries temporais. http://www.bcb.gov.br/?seriesfn (10 out. 2003)

BRASIL. Banco Central do Brasil. Resolução n.2.293 de 28 de junho de 1996. Dispõe sobre a exigibilidade de aplicações em crédito rural (MCR 6-2).

BRASIL. Banco Central do Brasil. Resolução n.2.399 de 25 de junho de 1997. Altera a fórmula de cálculo do patrimônio líquido de que trata o regulamento anexo IV à Resolução n. 2.099, de 17 de agosto de 1994.

BRASIL. Banco Central do Brasil. Resolução n.2.682 de 21 de dezembro de 1999. Dispõe sobre critérios de classificacão das operacões de crédito e regras para constituicão de provisão para créditos de liquidação duvidosa. 
BASTOS, N.T. Rentabilidade ajustada ao risco das operações bancárias de crédito. 2000. http://www.ibmec.br/sub/sp/article.php (27 nov. 2003)

BIGNOTTO, E.C. Medidas de risco e custos de transação: um estudo de caso com tradings e processadoras de café e soja. Piracicaba, 2002. 132p. Dissertação (M.S.)

- Escola Superior de Agricultura “Luiz de Queiroz”, Universidade de São Paulo.

CAOUETTE, J.B.; ALTMAN, E.I.; NARAYANAN, P. O próximo grande desafio financeiro. Rio de Janeiro: Qualitymark, 1999. 500p.

CROUHY, M.; GALAI, D.; MARK, R.A. Comparative analysis of current credit risk models. Journal of Banking \& Finance, v.24, p.59-117, 2000.

CREDIT SUISSE FINANCIAL PRODUCTS. CreditRisk+: technical document. 1997. http://www.csfp.com/creditrisk (10 Feb. 2002)

DUARTE JUNIOR, A.M. Alocação de capital econômico: conceitos e metodologias. /Apresentado ao 7. Encontro Nacional de Gestão de Riscos, São Paulo, 2003/

DUARTE JUNIOR, A.M. Risco: definições, tipos, medição e recomendações para o seu gerenciamento. 2000. http://www.ibmec.br/sub/sp/article.php (27 nov. 2003)

ELTON, E.J.; GRUBER, M.J. Modern portfólio theory and investiment analysis. 5.ed. New York: John Wiley \& Sons, 1995. 715p.

FIGUEIREDO, R.P. Gestão de riscos operacionais em instituições financeiras: uma abordagem qualitativa. Belém, 2001. 82p. Dissertação (M.S.) - Universidade da Amazônia.

GASQUES, J.G.; CONCEIÇÃO, J.C.P.R. Financiamento da agricultura: experiências e propostas. In: GASQUES, J.G.; CONCEIÇÃO, J.C.P.R. (Org.). Transformações da agricultura e políticas públicas. Brasília: IPEA, 2001. cap.2, p.95-155.

JORION, P. Value at risk. New York: McGrawHill, 1997. 332p.

JPMORGAN \& COMPANY. Credit Metrics $^{\text {TM: }}$ technical report. 1997. http://www.creditmetrics.com (10 Feb. 2002) 
LINSMEIER, T.J.; PEARSON, N.D. Risk measurement: an introduction to value at risk. Urbana-Chanpaing: University of Illinois, 1996. 44p. (Working Paper)

MERTON, R.C. On the pricing of corporate debt: the risk structure of interest rates. Journal of Finance, v.29, p.449-470, 1974.

PERERA, L.C.J. Decisões de crédito para grandes corporações. São Paulo, 1998. 298p. Tese (Doutorado) - Faculdade de Economia e Administração, Universidade de São Paulo.

PRADO, R.G.A.; BASTOS, N.T.; DUARTE JUNIOR, A.M. Gerenciamento de riscos de crédito em bancos de varejo. 2000. http://www.ibmec.br/sub/sp/article.php (27 nov. 2003)

SAUNDERS, A. Credit risk measurement: value-at-risk and other new paradigms. New York: John Wiley \& Sons, 1999. 226p.

SCHRICKEL, W.K. Análise de crédito: concessão e gerência de empréstimos. São Paulo: Atlas, 1997. 321p.

SECURATO, J.R. Um modelo para quantificar o risco de crédito. São Paulo, 2000. 122p. Tese (Livre Docência) - Faculdade de Economia e Administração, Universidade de São Paulo.

SECURATO, J.R. (Coord.). Crédito: análise e avaliação do risco: pessoas físicas e jurídicas. São Paulo: Saint Paul, 2002. 353p.

SMITHSON, C.W.; HAYT, G. Gerenciamento de carteiras de crédito pela maximização do retorno ajustado pelo risco. Revista Tecnologia de Crédito, n.39, p.5-8, 2003. http://www.serasa.com.br (20 out. 2002)

SMITHSON, C.W.; HAYT, G. Otimizando a alocação de capital. Revista Tecnologia de Crédito, n.36, p.61-78, 2003.

SOUZA, L.A.R. Teoria de valores extremos para cálculo de VaR. 2000. http://www.ibmec.br/sub/sp/article.php (27 nov. 2003) 